\title{
Kastamonu’da Üç Tarihî Külhan Kazanı
}

Mehmet Sami Bayraktar*

Öz

Bu çalışmada, Kastamonu il merkezinde bulunan üç tarihî hamama ait külhan kazanı tanıtılıp değerlendirilecektir. Bunlar İsmail Bey (Kurşunlu) Han'da sergilenen Kastamonu Vakıf Hamamı külhan kazanı, Kastamonu Pembe (Balkapanı) Han'da sergilenen Kastamonu Dede Sultan Hamamı külhan kazanı ve Kastamonu Münire Medresesi avlusunun kuzeydoğu köşesinde sergilenen Tosya Tekke Hamamı külhan kazanıdır. Kısmen tahrip olmakla birlikte kazanlar, orijinal görünümlerini büyük ölçüde korumaktadır.

Türk devrinde hemen her dönem güçlü bir siyasal sosyal ve ekonomik yapı sergileyen Kastamonu'nun zengin bir mimarî kültüre ve önemli anıtlara sahip olduğu bilinmektedir. Tarihî yapılarıyla paralel olarak şehrin geleneksel el sanatları bakımından da son derece iyi gelişmiş olduğu görülmektedir. Bu sanatlar içerisinde bakırcılığın iyi bir konumda olduğu söylenebilir. Dikkat çekici ölçülerdeki kazanlar, bu iş̧̧iliğin başarılı bir yansımasıdır.

Sanat Tarihi literatüründe külhan kazanlarını konu olan monografik bir araştırma bulunmamaktadır. Üç külhan kazanı ile sınırlı çalışmamız bu bağlamda bir başlangıç aşamasında görülebilir.

İncelediğimiz külhan kazanlarının en eskisi Çobanoğulları dönemine (1273-1274 dolayı) kadar inmektedir. Ülkemizde Anadolu Selçuklu, Beylikler ve Erken Osmanlı dönemine ait olduğu kesin olarak bilinen madenî eserlerin sayısının azlığı dikkate alınırsa, 1273-1274 civarında inşa edilen bir hamamda bulunan ve ilk inşadan kaldığı yönünde fikir veren külhan kazanının günümüze ulaşması son derece önemlidir. İlki gibi üzerlerinde kitabe bulunmayan diğer iki örneğin 1637 ve 1766-1767 yıllarına ait Osmanlı hamamlarında yer almalarına bakılarak Osmanlı eserleri olduğu anlaşılmaktadır.

Çeşitli tarihî belgeler, Kastamonu'nun Osmanlı devrinde önemli bir kazancılık ve bakırcılık merkezi olduğunu işaret etmektedir. Külhan kazanlarının, Anadolu'nun çeşitli vilayetlerine ve Anadolu dışına bakırdan mamul çeşitli kap-kacak ve alet-edevat ihraç eden Kastamonulu zanaatkârların elinden çıkmış olabileceğini düşünmekteyiz. Yakın zamanlara kadar her iki alanda da şehirde canlı bir üretimin olduğu bilinmektedir.

Anahtar Kelimeler: hamam, külhan, kazan, bakırcılık, zanaat, Kastamonu, Tosya, Çobanoğulları, Osmanlı.

\section{Three Historical Boilers in Kastamonu}

\section{Abstract}

In this study, three different historical bath boilers found in Kastamonu province are evaluated. These are the boilers of Kastamonu Foundation Bath exhibited in Ismail Bey (Kurşunlu) Caravanserai, Kastamonu Dede Sultan Bath exhibited in Kastamonu Pembe (Balkapanı) Caravanserai and of Tosya Tekke Bath exhibited in the north-east corner of Kastamonu Münire Madrasah. Although they are partly damaged, the boilers keep their original appearances to a large extent.

It is known that the city of Kastamonu, displaying powerful political, social and economical structure in almost all periods of Turkish era, has a prosperous culture and significant architectural monuments. Along with historical buildings, it seems that the city is in a fine position in terms of traditional handicrafts. It might be said that coppersmith has a distinguished position among these handicrafts. These enormous bath boilers reflect products of this excellent craftsmanship. In the literature of art history there is not any particular research about the bath boilers. This study which is limited to three boilers, may be seen as an initial work in this context.

The oldest of these boilers dates back to the period of Çobanoğulları Principality (1272-74). It is really important that the boiler which is found in a bath built around the years 1272-1274, has survived up to the present time when we consider the scarcity of metalworks that are certainly dating from Seljukid, Principalities and Early Ottoman periods in our country. It is also thought that this boiler is the one that was originally placed and used when the bath was first built. The other boilers do not have any inscriptions like the first one and it is thought that they are Ottoman works dating from 1637 and 1766-67. A variety of historical documents indicate that Kastamonu was an essential center of the coppersmith and the boiler making in Ottoman period. We think that these boilers were works of craftsmen from Kastamonu who exported various utensils and instruments made from copper to inside and outside of Anatolia. It is known that there has been a vivid manufacturing of coppersmith and boiler making in the city in recent years.

Key Words: bath, boiler rom, boiler, coppersmith, craft, Kastamonu, Tosya, Çobanoğulları, Ottoman.

* Yrd. Doç. Dr. Ondokuz Mayıs Üniversitesi, Fen-Edebiyat Fakültesi, Sanat Tarihi Bölümü; msami.bayraktar@omu.edu.tr / ms.bayraktar@hotmail.com 


\section{Giriş}

Çalışmamızın başında bizzat külhan kazanlarını konu alan bilimsel bir çalışmaya rastlamadığımızı belirtmek isteriz. Genelde hamam konulu monografik yayınlarda yeri gelirse değinilen külhan kazanlarıyla dolaylı ilgili az sayıdaki çalışmada, konuya ilişkin değerli bazı tanımlama ve tespitlere rastlanmaktadır. Geleneksel sanatlarımızın birçok alanında yayın ve belgeleme çalışması yapılmasına karşın bu alanda bir boşluk olduğu görülmektedir. İncelediğimiz külhan kazanlarını karşılaştırma yapabileceğimiz bir yayın ve kazanlarla ilintili daha önce yapılmış -kısa ve genel tanımlar dışında- çizim, fotoğraf ve belgeleme örnekleri bulunmadığından, çalışmamız, maden sanatımızın ve mimarimizin ve bir parçasını oluşturan külhan kazanları hakkında bir başlangıç aşamasında görülebilir. Zira pek çoğu ortadan kalksa da halen müzelerde veya tarihî hamamlarda kullanılır vaziyette veya başka şekilde mevcut bulunan kazanlar araştrılarak konuyla ilgili kapsamlı bir tanıtım ve değerlendirme yapılabilir. Bu çalışma Kastamonu il merkezinde ait oldukları hamamlardan alınarak sergilenen üç hamam kazanı ile sınırlıdır. ${ }^{1}$ Belirtilen kazanların tarihçeleri, fizikî ve teknik özellikleri üzerinde durulmuş, külhan kazanlarıyla ilgili bazı tespit ve çıkarımlara varılmak hedeflenmiştir.

\subsection{Kastamonu'nun Tarihî ve Mimarî Zengin- liğine Kısa Bir Bakış}

Kastamonu yöresi tarihinin arkeolojik veriler ışığında "Alt Paleolitik-Yontma Taş" safhasına kadar indiği, takibinde "Orta Paleolitik", "Geç Kalkolitik" yoğun olarak da "ilk Tunç çağına" ait yerleşme ve buluntulara rastlanıldığı, yerleşmelerde Hitit, Frig, Pers, Helenistik ve Roma çağla-

1 Birçok tarihi hamamda külhan kazanlarının maddî ederleri yüzünden eritilerek ortadan kaldırılmasına karşılık bu örneklerin korunması ayrıca bir bahtiyarlık vesilesidir. Vakıf eserlere ve bunların müştemilatına gösterilmesi gereken ilgi ve korumacı yaklaşımın bir ifadesi olarak kazanların, halkın görebileceği açık alanlarda sergilendiği dikkat çekmektedir. Vakıflar idaresi tarafindan müzelerin kapalı ortamı yerine, kazanların, tarihi mekânlarda günlük hayat pratiğine katılarak sergilenmesi tercih edilmiştir. rına kadar az da olsa bir sürekliliğin izlenebildiği ifade edilmektedir (Şahin, 2001: 585). Kronolojik olarak yöre, Kaşka (Gaşka), Hitit, Frig, Lidya, Pers, Makedon, Pontus, Roma, Bizans, Anadolu Selçukluları, Dânişmendliler, Çobanoğulları, Candaroğulları ve Osmanlı hâkimiyetine sahne olmuştur (Bilici, 1991: 2-3; Şahin, 2001: 585).

Türkler'in Kastamonu yöresini hangi tarihte fethettiği belli değildir. Ancak 1071 Malazgirt Savaşı'ndan sonra Anadolu Selçuklu Devleti'nin kurucusu Süleyman Şah’a bağlı beylerden Emîr Karategin 1084 yılından sonra kısa süre de olsa Kastamonu yöresinde hüküm sürmüştür (Şahin, 2001: 585). Ardından Bizans hâkimiyetine giren Kastamonu, kısa bir süre sonra Dânişmendliler tarafindan fethedilmiş ve bir süre şehir, Bizanslılar'la Dânişmendliler arasında el değiştirmiştir. Kastamonu ve yöresi, 12. yüzyıl sonlarında Anadolu Selçukluları́nın uç beyi Emîr Hüsâmeddin Çoban'ın kurduğu Çobanoğulları Beyliği'nin idaresi altına girmiş (Yücel, 1993a: 354-355; Şahin, 2001: 585), 1243 yılındaki Kösedağ Savaşı'ndan sonra Moğollar’a tâbi olmak üzere Pervaneoğulları tarafindan yönetilmiştir (Bilici, 1991: 5). Çobanoğulları topraklarının 14. yüzyıl başlarında Kastamonu ve Sinop civarında kurulan Candaroğulları Beyliği tarafindan ilhak edilmesiyle Kastamonu, beyliğin merkezi haline getirilmiştir (Şahin, 2001: 585). Kastamonu yöresindeki ilk Osmanlı hâkimiyeti 1392 yılında (Yücel, 1993b: 148) Yıldırım Bayezid döneminde gerçekleşmiş, Çelebi Mehmed döneminde Osmanlılar zaman zaman Kastamonu ve yöresine hâkim olmuşlardır. Sonuçta Fâtih Sultan Mehmed, Candaroğulları Beyliği'ne son vererek 1461 yılında Kastamonu ve yöresini kesin biçimde Osmanlı topraklarına ilhak etmiştir (Şahin, 2001: 585-586; Maden, 2007: 151).

Türk idaresine girinceye kadar önemli bir gelişme gösteremeyen Kastamonu özellikle Çobanoğulları döneminde nüfus, fizikî yapı ve mimarî eserler yönünden şehir hüviyetini ka- 
zanmaya başlamış, Çobanoğulları döneminde cami, mescit, hamam, dârüşşifa ve zâviye gibi eserlerle donatılmıştır (Yücel, 1993a: 354; Şahin, 2001: 586-587). Candaroğulları devrinde fizikî bakımdan daha da gelişen Kastamonu, kalenin doğu, batı ve kuzey taraflarına doğru genişlemiştir. ${ }^{2}$ Osmanlı döneminde 15 . ve 16. yüzyıllarda da istikrarlı bir şekilde büyümeye devam eden şehirde birçok vakıf eser inşa edilmiştir (Eyüpgiller, 1999: 98-218; Şahin, 2001: 586; Maden, 2007: 239-269). 17. ve 18. yüzyıllarda nispeten şehrin büyümesinin durağanlaştığı 19. yüzyılda "şehrin fizikî bakımdan büyümediği, yüzyılın ortalarından sonra kuzey ve güneydeki nihaî sınırlarına ulaştığı" bu yüzyılın son çeyreğinden itibaren "Kastamonu Bat'dan esinlenmiş, askerî, mülkî ve kamuya ait binaların inşasıyla yeni bir fizikî değişim" yaşandığı görülmektedir (Bilici, 1991: 272-281; Şahin, 2001: 586).

Bat Karadeniz'in önemli şehirlerinden Kastamonu, Türk devrinde hemen her dönem güçlü siyasal bir yapılanmaya sahne olmuştur. Kastamonu, bu siyasal yapı ile paralel bir şekilde güçlü sosyo-ekonomik bir gelişim göstermiştir. Şehirde Çobanoğulları, Candaroğulları ve Osmanlı dönemlerinden kalma birçok vakıf eseri ve tarihî bina bulunmaktadır (Bilici, 1991: 209 -282, 293-302; Eyüpgiller, 1997; Şahin, 2001: 586; Şakar, 2008: 243-257). Küre'de bakır madeninin çıkarılması (Tızlak, 1999a: 411; İbret, 2003: 53; Maden, 2007: 151-154,157; Avcl, 2012: 19) ekonomik gelişmenin önemli bir destekçisi olması yanında, geleneksel bakır işçiliğinin gelişmesine de sebep olmuştur.

\subsection{Bakır Madeni ve Bakır Eşyalar}

"Doğada serbest ya da bileşik olarak bulunan kızıl renkli bir maden olarak" tanımlanabilen

2 "Candaroğulları Beyliği iktisadî bakımdan iyi bir mevkide bulunuyordu. Çünkü Karadeniz'in en iyi liman şehirlerinden olan Sinop bu beyliğin elindeydi. Burası hem ihracat limanı hem de gemi tersanesinin bulunduğu bir yerdi. Beyliğin en önemli ihraç maddelerini bakır ve demir teşkil ediyordu. Cins atları ve avcı kuşlarıyla da ünlü olan Kastamonu bu özelliğini Osmanlılar zamanında da korumuştur." (Yücel, 1993b: 149).
(Anonim, 1997a: 182) bakır, ${ }^{3}$ keşfedildiği çağdan itibaren en çok kullanılan maden olmuştur. Yakın zamanlara kadar hem şekil verilebilirliği hem de şeklini koruması açısından tercih edildiği gibi sağlam ve uzun ömürlülüğü sayesinde, geniş bir ürün yelpazesinde günlük hayatın bir parçası olarak önemini korumuştur. Özellikle dövme tekniği için elverişli olan bakır, yukarıdaki özelliklerine ilaveten ısıyı çok iyi ilettiği için külhan kazanlarında kullanılması yerinde olmuştur. $^{4}$

3 "Kimyada Simgesi "Cu", yoğunluğu 8.9 ve ergime derecesi $1083^{\circ \mathrm{C}}$ olan kimyasal bir elementtir. Kolay işlenebilirliğinden dolayı erken çağlardan beri kullanılmakta olan bakır, çok iyi bir Isı ve elektrik iletkeni olduğundan özellikle sanayide yaygın bir kullanım alanına sahiptir. El sanatlarında ve oymabaskı sanatında da yaygın olduğu gibi, aşınma dayanıklılığı nedeniyle kuyumculuk ve saatçilikte de aranan bir gereçtir. Ayrıca, ince levhalar halinde üretilen bakır, işçilik kolaylığı, dayanıkılığı ve öteki kaplama malzemelerine göre hafifliği dolayısıyla özellikle 20.yy'da çat kaplaması alanına girmiştir. Bakır çatılarda zaman içinde nemin etkisiyle yüzeyde, küf renginde bir pas tabakası oluşur. Türkiye'de anıtsal Osmanlı yapılarındaki kurşun çatı kaplama geleneği, kurşunun çok pahalı bir gereç olmasından dolayı Cumhuriyet döneminin bazı anıtsal yapılarında bakırla sürdürülmüştür."' (Anonim, 1997a: 182).

4 "Bakır: Doğada hem doğal maden hem de cevher olarak bulunur. Doğal bakır dere yataklarında ya da bakır cevherlerinin aşınmış üst katmanlarında görülür. Bakır, okside olan bir madendir; yüzeyi zaman içinde morumsu yeşil bir renk aldığından altın gibi kolay göze çarpmaz. Ancak okside olmuş bakır parçaları elle ovulunca alttaki kırmızı renk ortaya çıkar. Doğal bakır çok az bulunur; bakır cevherleriyse bol ve yaygındır. Bu cevherler bazan kimyasal bileşik, bazan da fiziksel karışım halindedir. Üst katmanlarda bakır oksitleri ve bakır karbonatları, derinlerde bakır sülfürleri olarak bulunurlar. Bakır cevherlerinden arıtmayla bol oranda metalik bakır elde edilebilir. Doğal bakır, arıtıımış bakırdan daha saf bir madendir. Doğal bakırda çok az oranda altın, gümüş, demir ve antimon bulunmasına karşın, cevherden sağlanan bakırda bunların yanı sıra çinko, kurşun, arsenik, nikel ve kalay gibi madenler de bulunur. Cevherden arıtılan bakır, ikinci bir işlemle saflaştırılır. En kolay saflaştırma yöntemi, erimiş madenlerin üstüne hava akımı vererek, örneğin üfleyerek, oksidasyon sağlamaktır. Hava üflendiğinde, bakırın içindeki öteki madenler bakırdan önce okside olarak yüzeye çıkarlar ve bu cüruf (maden posası) potadan alınarak bakır saflaştırılır. Bakır, altın ve gümüşten daha sert bir madendir. Soğukken dövülürse sertleşir ve işlenemez. Dövülürken sertleşen bakır ateşte ısıtılarak yumuşatılır. Ancak bakır çok sıcakken (akkor halde) de çekiçlenemediğinden soğuk suya daldırılarak ılıklaştırılır; ani soğumayla daha da yumuşar. Bakırın önce ısıtılıp, sonra suya daldırılarak yumuşatılmasına "tavlama" denir. Tavlamanın keşfi, maden sanatının ana yapım tekniklerinden biri olan dövme tekniğinin gelişmesine yol açmıştr. Bakır, özellikle dövme tekniği için elverişlidir; eridiği zaman kabarcıklandığından döküm için uygun değildir. ” (Erginsoy, 1997: 1139). 
Bakırın kullanıldığı eşya, gereç ve silahlara "Kazan, güğüm, mangal, tabak, bakraç, sabunluk, ateş küreği, ayakkabı çekeceği, ayna, buhurdan, ibrik, çıngırak, divit, taş, şamdan, sefer tası, fincan zarfi, gülabdan, kupa, leğen, hançer, havan-havan eli, iftariyelik, kahvelik, kahve sitili, balkan, kandil, kantar, kapı tokmağı, kazan kulpu, kemer tokası, külek, kül tablası, küp, miğfer, minare alemi, musluk, nargile mangalı ve söndürücüsü, sebil, şifa tası" gibi örnekler verilebilir (Gülensoy, 1994: 6-7).

\subsection{Türk Maden Sanatı ve Bakıcılık Sanatına Kısa Bir Bakış}

Taş devrini kapatıp maden devrine geçişi sağlayan bakır, insanlığın tarihsel sürecinin en önemli aşamalarından birinde rol alan önemli bir madendir. Doğal bakır, altın ve doğal gümüş ile birlikte Neolitik Çağ insanının dikkatini çeken ilk madenlerden biridir. (Kayaoğlu, 1985: 439-440; Erginsoy, 1997: 1140; Eraslan, 2009: 378; Başak, 2010: 19-20). Anadolu, maden sanatı açısından dünya çapında öneme sahip bir bölge olmuştur. ${ }^{5}$

Anadolu öncesinde kurulan Türk devletlerinde de madencilik önemli bir ekonomik uğraş alanı olmuştur. Bununla ilintili olarak gelişmiş bir metal teknolojisi ve maden sanatımızdan söz edebiliriz. Türk maden sanat ilk olarak Asya Hunları devrinde başlar (Kerametli, 1974: 115-117). Bu dönemde, kendine özgü bir üslup (Avrasya hayvan üslûbu) ve teknik olarak iyi düzeyde çok sa-

5 Maden sanatının büyük uygarlıkların beşiği olan Yakındoğu topraklarında; Mısır, Mezopotamya, Anadolu ve İran'da geliştiği (Erginsoy, 1997: 1140), madencilikte ilk önemli adım olarak kabul edilen "tavlama"nın keşfinin arkeolojik kazı sonuçlarına göre, Neolitik Çağda Anadolu'da gerçekleştiği (Erginsoy, 1997: 1141) bildirilmektedir. Teknoloji tarihçileri, demir cevherlerinin arıtılmasının ve dövme demirin elde edilmesinin ilk kez Anadolu'da Eski Hitit Krallığı döneminde (MÖ. 1800-1400) gerçekleştirildiğini; çeliğin de Hitit İmparatorluğu döneminde (MÖ. 1400-1200) yapıldığını belirtmektedirler (Erginsoy, 1997: 1140). Metalürjik keşiflerin ve maden sanatı tekniklerinin hemen hepsinin Milattan önceki 7000 yıllık süreç içinde, Yakındoğu topraklarında gerçekleştirildiği, Eskiçağı izleyen Orta ve Yeniçağlarda maden sanatını etkileyen önemli metalürjik keşifler olmadığı, ancak metalürjik yöntemlerde ve maden bezeme tekniklerinde gelişmeler kaydedildiği dikkat çekmektedir (Erginsoy, 1997: 1144; Başak, 2010: 13-33). yıda madeni eserle ${ }^{6}$ karşılaşmaktayız. Akhunlar, Avrupa Hunları, Göktürkler, Uygurlar, Avarlar ve Peçenekler ve diğer bazı irili ufaklı Türk devletlerinden sonra ${ }^{7}$ maden sanat İslami dönemde de devam etmiştir (Kerametli, 1974: 116-125). Orta Asya göçebe sanatının etkilerinin hissedildiği Büyük Selçuklu ve onların atabeyleri ve ardılları konumundaki Zengiler, Artuklular, Anadolu Selçukluları ve Eyyubiler döneminde maden sanatının büyük bir atlım gösterdiği; ilk olarak Büyük Selçuklu döneminde malzeme, teknik, kap türü, kap biçimleri ve süsleme alanında birçok yenilik gerçekleştirildiği bilinmektedir (Erginsoy, 1978: 500-506,510; Bodur, 1987: 23-36; Aslanapa 2011: 333-339) ${ }^{8}$. Zengin teknik, biçim ve bezeme özellikleriyle Türk maden sanat, Orta Asya'dan Anadolu'ya kadar uzanarak, Türk sanatının önemli bir kolu olarak gelişimini bu yeni coğrafyada da sürdürmüştür. Anadolu Selçukluları, Artuklular ve Anadolu Selçukluları çağdaşı diğer bazı beyliklerde, maden sanat genel hatlar itibariyle Büyük Selçuklu üslûbunun da izlenebildiği fakat bunun yanı sıra "değişik bölge ve kültür etkilerinin biçimlendirdiği sanatsal çeşitlilik ve çok yönlü" bir karakteristiğe sahip olmuştur (Erginsoy, 1978: 336-337). Türk maden sanat Osmanlı'ya kadar hemen tüm imal ve süsleme tekniklerini denemiş, çeşitli biçimleri geliştirmiş olduğundan Osmanlı maden sanatının bu hazır miras üzerinde yükseldiği ifade edilmektedir (Bodur, 1987: 36). Osmanlı devrinde çok sayıda ve türde nitelikli eserler vermiştir. Osmanlı topraklarında çeşitli bölgelerde birbirlerinden farklı teknik ve biçim diline sahip son derece zarif ve çok çeşitli türde eserler verilmiştir (Bodur, 1987:

6 Büyük çoğunluğunu silah, araç, gereç, süs ve dini içerikli madeni eşyaların oluşturduğu Hun devri madeni eserlerin büyük bir kısmı bilindiği üzere kurganlardan çıkarılmıştır.

7 "Tarih ve coğrafyaya ait eski Türk, Çin ve Arap kaynaklarının hepsinde Türklerin atalarının demirci olduğundan” bahsedilmektedir (Tızlak, 1999a: 407). İslam öncesi Türk maden sanat hakkında geniş bilgi için bkz. Bodur (1987: 12-20); Birkan (2005); Çoruhlu (2007: 139-141, 212-213, 336-350, 355-367).

8 Erginsoy’a göre Büyük Selçuklu devri, İslam maden sanatının doruğa ulaştı̆̆ dönem olmuştur (Erginsoy, 1978: 510). 
36-50; Kuşoğlu, 2002: 194-205). 16. ve 17. yüzyılda klasik devrini yaşayan Osmanlı maden sanat diğer hemen tüm sanat alanlarında olduğu gibi, 19. yüzyıldan sonra Batılı tesirle barok ve rokoko tarzının hâkim olduğu yeni bir modayı yansıtmıştır. ${ }^{9}$ Özellikle 18-20. yüzyıllar arasında bakır eşya türlerinde güçlü bir artış olduğu ifade edilmektedir (Barışta, 2015: 750).

Bu çalışmanın konusunu oluşturan 13. ve 16.17. yüzyıllara ait külhan kazanların dayandığı maden sanat ve teknolojisinin temellerinde kanımızca hem yukarıda belirtilen eski Anadolu geleneği hem de Anadolu öncesi Türk maden sanat geleneği bulunmaktaydı.

Anadolu bakırcılığının Bizans döneminde iyi düzeyde olduğu, Avrupa Anadolu ve Ortadoğu çapında önemli sanat atölyelerinin Konstantinapolis'te bulunduğu bilinmektedir. Türk fetihlerinden sonra Anadolu'da bakır kap-kacak yapımında büyük bir artış olduğu, İstanbul'un fethini takip eden yeni imâr döneminde Türkler tarafindan İstanbul'da açılan çok sayıda bakırcı dükkân ve çarşısının (kazgancı) bulunduğu, Anadolu'da Bursa, Konya, Kayseri, Sivas, Tokat, Erzincan, Bayburt, Erzurum, Trabzon, Siirt, Mardin, Diyarbakır, Cizre, Harput, Malatya gibi birçok şehirde üretim yapan bakırcı atölyelerinin İstanbul ile birlikte Anadolu'nun ihtiyacına cevap vermekten başka Irak, Suriye, İran gibi ülkelere bakır mamulü eşya ihraç ettiği anlaşılmaktadır (Belli ve Kayaoğlu, 1993a: 32). ${ }^{10}$

\subsection{Kastamonu'da Geleneksel Bakırcılık}

Kastamonu, geleneksel bakırcılık bağlamında Anadolu'da ilk akla gelen ve kaliteli bakır işlerinin üretildiği şehirlerimizden biri olmuştur (Belli ve Kayaoğlu, 1993b: 553; Erginsoy, 1997: 1146;

9 Geniş bilgi için bkz. Erginsoy (1997: 1146-1147).

10 Bazı seyyahların ifadesiyle bakırdan yapılmış kap-kacağı Türkler kadar seven başka bir millet bulunmadığı ifade edilmektedir (Belli ve Kayaoğlu, 1993a: 32). Balkanlarda Osmanlı hâkimiyetinden sonra bakır eşyaya ilginin arttğı, Türklerin tesiriyle diğer milletlerde bakır kullanımının yaygınlaştı̆̆ı, Makedonya'ya kazancılığın Türkler tarafindan getirildiğini savunan araştrmacılar bulunmaktadır (Koneska, 1992: 141-147).
Karpuz, 2002: 426; Kuşoğlu, 2006: 36). Küre'den çıkan bakır cevheri Kastamonu'da önemli bir üretim ve ticaret hammaddesi olmuştur (Belli ve Kayaoğlu, 1995: 44-46 ; Darkot, 1977: 401). Küre'den çıkarılan bakır cevherinin Candaroğulları devrinde İsfendiyar Bey döneminde Kastamonu başta olmak üzere Anadolu'nun diğer şehirlerine gönderildiği hatta Avrupa ve İran'a ihraç edildiği ve bu üretimin 16 . yüzyılda da canlı olduğu bilinmektedir (Belli ve Kayaoğlu, 1993a: 14-15,165-166; Eyüpgiller, 1999: 44-45; İbret 2001: 436-438; Yakupoğlu 2001: 73).

Kastamonu çevresindeki bakır yataklarının Osmanlı döneminde de işletildiği ve bakırcılığın iyi düzeyde olduğu çeşitli araştırmacılarca ifade edilmektedir (Belli ve Kayaoğlu, 1993a: 4950, 60, 166-177). Kastamonu'yu 1640 ve 1660 yıllarında ziyaret eden Evliya Çelebi, "Esnâf-ı kalaycıyân" başlığı altında Kastamonu bakır işçiliğinden övgüyle söz ederek bütün kazancıların Kastamonulu olduğunu belirtmektedir. ${ }^{11}$ Evliya

11 “Esnâf-ı kalaycıyân: Dükkân 106, neferât 500, pirleri Hazret-i Sâri'dir kim Hazret-i Alî belin bağladı. Hazret-i Ömer hilâfetinde Acem diyârında Nihâvend Seferi'ne serdâr olup vardukda Acem gâlib gelüp Sâri münhedim olmak sadedinde iken Medine 'de de Hazret-i Ömer cum'a günü hutbe tilâvet iderek kalb gözleriyle gördü kim Sâri münhedim oluyor. Hemân minberde hutbe esnasında "Yâ Sâriye ile'l-cebel" deyü Hazret-i Ömer bir na'ra itdükde cümle cemâ'at hayrân kalup Ömer'e ateh galebe idüp beş aylık yolda Nihâvend'de olan Sâriye'yi hâtırına getirüp hutbede galat itdi didiler. Kimi esrâr-ı hafisine hami idüp târih kodular. Hazret-i Ömer'in bu na'rasın Nihâvend'de olan guzât-ı muvahhidîn cümle istimâ' idüp hemân Sâri hazretleri alem-i Resûlullahı ile'l-cebel didüğü gibi dağa alem çeküp cebele arka virüp mansûr [u] muzaffer Medine'ye gelüp târihleri mutâbık gelüp Hazret-i Ömer'e ziyâdesiyle muhabbet itdiler. Me'âl-i kelâm bu kalaycıların piri Şeyh Sâri hazretleridir kim kâhîce gazalara serdâr olurdu. Kabr-i münevveresi, Mısır'ın iç kal'asında Tavâşî Süleyman Paşa Câmi'i hareminde okuyla ve yayları ile dokuz kademe nerdübân ile inilir bir gârda medfûndur. Bunlardan sonra kazancıbaşının güzide askerlerinin omuzlarında niçe bin yelteme ve sayâlma ve yassılama ve danlama bâm isimli çekiçler ile ubûr iderken yollarda bir tomruğu meydân-ı muhabbete koyup on dör[d] ve on alt kişi usûl-ı âheng ile ol tomruğa çekiçler çalup arz-ı mahâret iderek ubûr idüp gûnâ-gûn kazancı şakaları iderler ammâ bu esnâfin ihtiyârlarının kaba sakallılarının bakır râyihasından cengârî ve kebritî ve yeşil ve mavi sakalları vardır. Bunlardan sonra kazancıbaşı ve çarkçıbaşı at başı berâber olup ardları sıra Kastamonu ve Bakır küresi ve Taşköprülü Türk dilbercikleri iç oğlanları pâyesiyle ubûr iderler. Zîrâ bu kazancılar cümle Kastamonuludur, ardları sıra sekizer kat mehterhâne ile ubûr iderler. Bu kazancıbaşı yamağı cümle (-) altı esnâfdır ve dahi cümle (-) dükkândır." (Dağlı, 2003: 203). 
Çelebi, Kastamonu kazancılarının çalışma düzenleri hakkında da bazı bilgiler verir. ${ }^{12} 1849$ 'de Kastamonu'da kalhâne ${ }^{13}$ ve bakırcı esnafi olduğu, Yakup Ağa Külliyesi İmareti ve çevresindeki başka dükkânların, 19. yüzyılın sonu ve 20 . yüzyılın başlarında bakır eritimiyle uğraştkkları, bakırcılığın 1842 ve 1862 yılında şehri ziyaret eden seyyahların da ifade ettiği üzere önemli bir iş kolu olduğu anlaşılmaktadır (Eyüpgiller, 1999: 45). ${ }^{14}$ 1833-37 ve 1843 yıllarında Türkiye'yi iki kez ziyaret eden Charles Texier, Kastamonu halkının zanaat ve hüner sahibi olduklarından söz ederek şehrin geçiminin biri bez dokumacılık diğeri bakırcılık işi olmak üzere iki çeşit endüstri

12 Evliya Çelebi'nin gezdiği bazı şehirlerdeki bakır işçiliği hakkında yorum yaparken sık sık Kastamonu ile kıyaslamalarda bulunduğu görülmektedir: "Der-beyân-ı memdûhât-ı kâr-ı ahâlî-i şehr-i Tokat: Evvelâ beyâz pembe bezi ve câm tasları diyâr-ı Lahor'da yapılmaz. Gûyâ altun gibi mücellâdır. Ve kalemkârî basma yorgan yüzleri ve münakkaş perdeleri ve kazancı kârından suhûn ve tancereleri Kastamonu ve Belgrad ve Bosna'da işlemek ihtimâli yokdur, zîrâ cümle âvânîsi kalemkâr işi savatlıdır."... "Andan hacer-i lâciverd ma'deni olur, ammâ Firengî gibi bin reng değildir. Ve kurşum ma'deni olur. Anıniçün bu Sarây şehrinde kurşum ile örtülmüş imâretler çokdur. Ve nühâs-ı hâlis ma'deni olur, ammâ nâdirdir, lâkin "içinde altunu vardır" dirler. Anıniçün Bosnasarâyı'nda işlenen bakır âvânîleri Belgrad ve İslâmbol ve Kastamonu ve Tokat'da işlenmez. Hattâ altun ile mutallâ gûnâ-gûn şam'dân ve buhûrdân ve gülâbdânlar işlerler kim görenler anları zeheb-i Bundukanî zann eder. Ve hadîd ma'deni gâyet çokdur. Hattâ Foniçsa nâm kasaba dağlarında bî-hadd ü bî-kıyâs demir meğer Sofya-i sâfiye Samakov'unda çıka ve bu Foniçsa kasabasında işlenen demir silâh âlâtları şehr-i Virene 'de ve Taşlıca'da ve Çaniçse kasabalarında işlenmez"... "[Kıratova şehri] Ve cümle üç yüz elli aded dükkânları var. Her esnâf mevcûddur, ammâ Kazancılar çârsûsu gâyet müzeyyen sûk-I sultânîdir. Bu şehirde nühâs ma'deni olmağile bunda işlenen nühâs âvânî ne Bosna ve ne Kastamonu ve Küre şehrinde ve Tokat kal'asında işlenmez. Hattâ müşebbek şanı'dân ve buhûrdân ve fânûs ve leğenler ve gûnâ-gûn münakkaş sürahi zeheb-i hâlis ile mutallâ ibrikler işlenir kim sîm-i hâlisden ancak işlenir üstâdları vardır." (Dağlı, 2003: 203).

13 Kalhane (dökümhane), "Alttn gümüş ve sair madenleri ve eski sırmaları eritip külçe haline getirmeğe ve döküme hazırlamağa mahsus ocaklı yerler" şeklinde tarif edilmektedir. (Arseven, 1963: 91; Pakalın, 1983: 151). Ayrıca bkz. Kuşoğlu (2006: 121, 123).

14 “Ainsworth, 1842'de Kastamonu'da erkeklerin bakırclıkla uğraştıklarını yazarken. 1862'de Texier, kentteki belli başlı endüstri kollarından birinin bakırcılık olduğunu belirtmekte, bu dönemde bakır avadanlıklar (mangal, sefertası, cezve) üretilerek İstanbul'a gönderildiğini eklemektedir. 1306 H/1888-9 M. yılında Kastamonu'da bakır sefer tasları, sahan, akder, su sürahisi, içiçe geçer su bardakları, tencereler imal edilmekte ve satılmaktadır." (Eyüpgiller, 1999: 45). kolu yoluyla olduğunu, bu itibarla bakır avadanlıklar, kazanlar, mangallar, sefer tasları, mutfak malzemeleri ve Avrupa'da doğu kahve ibriği denilen cezveleri üretip, İstanbul’a gönderdiklerini belirtmektedir (Maden, 2016: 31).

18. yüzyıl sonu ile 19. yüzyıl başlarında iyi bir düzeyde olduğu görülen Kastamonu bakırcılık zanaat (Faroqhi, 1994: 223-224) 1920'li yıllarda sona ermeğe başlamıştır. ${ }^{15}$ Kastamonu Ticaret Odası kayıtlarına göre 1934-1936 yılları arasında Kastamonu'da bakırcılık mesleğiyle ilgili olarak 50 usta, 35 kalfa ve 48 çırak çalışmaktaydı. 1942 yılında Bakırcılar Çarşısı'ndaki atölye sayısı 22 iken, bugün bu sayı ancak 2-3 civarındadır (Belli ve Kayaoğlu 1993a: 168; Kazmaz, 1997: 113). Şehri 1941 yılında ziyaret eden Nahid Sırrı Örik bakırcılar çarşısındaki bakır dövülen dükkânlardan söz etmekte birlikte bakır eşya imalatna değinmemektedir (Maden, 2016: 88-89). 1989 yılında yayınlanan bir araştırmaya bakılırsa bu yıllarda Kastamonu'da 16 kadar bakırcı dükkânı bulunmaktaydı (Tan, 1989: 38) Günümüzde ise üretim durmuş haldedir. İşi bırakmış epey yaşlı bir iki usta, eski bakır eşyaların satıldığı birkaç dükkân ile kalaycılığa devam eden sadece bir dükkân ve usta belirleyebildik ${ }^{16}$ (Resim 1).

Kazancılık mesleğinin Kastamonu'da bir sanata bağlı olarak icra edilen meslekler arasında yer aldığı tarihi belgelerde de görülmektedir (Cunbur, 1988: 13-14; Belli ve Kayaoğlu, 1993a: 167168 ; Güzey, 2001: 131; Yakupoğlu, 2009: 170). Kastamonulu bakırcıların -diğer birçok Anadolu şehrinde olduğu gibi- kendilerine has üslup sahi-

15 “Bu yıllarda, Bakır Küresi'ndeki madenlerin çalışmaması hammadde akışını durdurmuş, çok sayıda usta İstanbul'a göç etmiştir. Kalan bakırcı esnafi, bu dönemde, İstanbul'daki esnaftan pahalıya çalışmaktadır. Günümüzde de eski belediye binasının doğusunda "Kazancılar Mescidi" yer almakta, güneyinde ise "Bakırcılar Çarşısı" adını taşıyan bir sokak ve burada halen bu zenaati sürdüren birkaç bakırcı ve kalaycı dükkânı gözlenmektedir. Ancak, üretim kısıtlı olup, daha çok kalaycılık ve eski kapların satışı yapılmaktadır." (Eyüpgiller, 1999: 45).

1664 yaşındaki kalaycı Raşit Yazıcı, Cem Sultan Bedesteni'nin batısındaki tarihi bakırcılar çarşısında yer alan küçük dükkânında mesleğine devam etmektedir. 
bi oldukları ifade edilmektedir (Belli ve Kayaoğlu 1993a: 168), (Resim 2-5). Araşttrma konumuz olan külhan kazanlarını bakırcılıkta mahir olduğu bilinen şehirdeki kazancılar imal etmiş olmaIıdır. "Erzurum'da yapılan baruthane için gerekli olan kazan ve diğer aletlerin" hazırlanması işinin Kastamonu'ya havale edildiğini gösteren belge gibi bazı tarihi belgeler (Belli ve Kayaoğlu 1993a: 167-168), Kastamonu'nun Osmanlı devrinde önemli bakır alet-edevat ve kazan imalat yeri olduğuna işaret etmektedir. Bakırcılık ve kazancılığın şehrin en önemli sanayi üretimini oluşturduğu söylenebilir (Belli - Kayaoğlu 1993a: 167168 ; Maden 2004: 32-33).

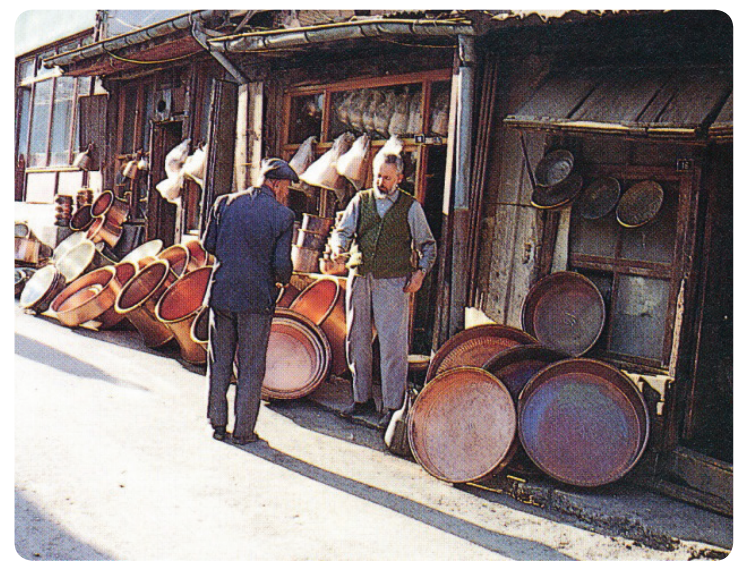

Resim 1. Kastamonu bakırcılar çarşısı (Belli ve Kayaoğlu,1993a: 165).

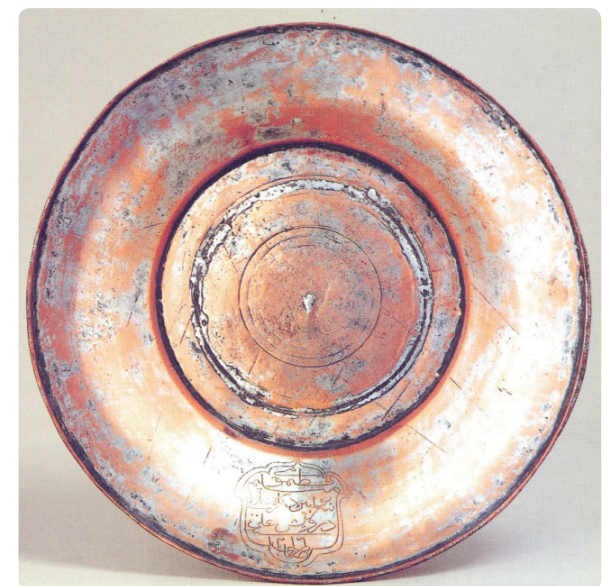

Resim 2. Kastamonu imalât dövme kitabeli bakır sahan, yükseklik 4,5 cm., çap $28 \mathrm{~cm}$. kitabe: "Sahibi Derviş Ali Ser Bevvabin-i Dergâh-ı Âli Müsellim-i Kastamoni 1216" (1801-1802) (Belli ve Kayaoğlu 1993a: 174).

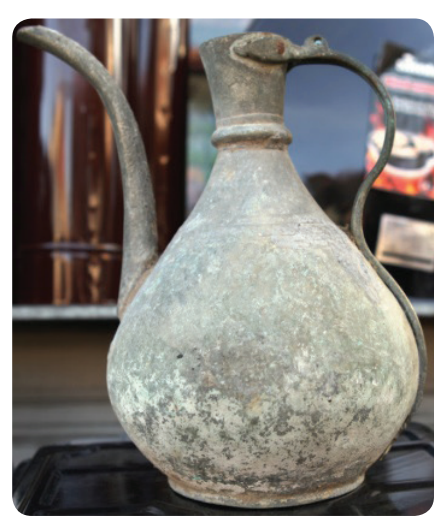

Resim 3. Kastamonu imalat ibrik (Kastamonu Bakırcılar Çarşısı).

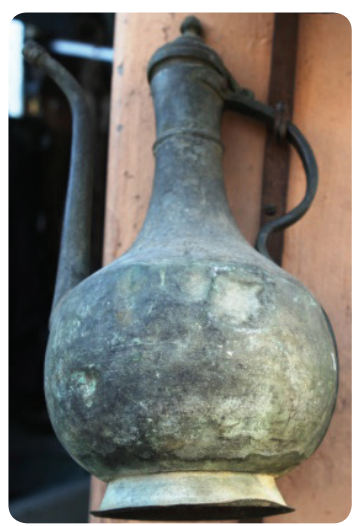

Resim 4. Kastamonu imalat ibrik (Kastamonu Bakırcılar Çarşısı).

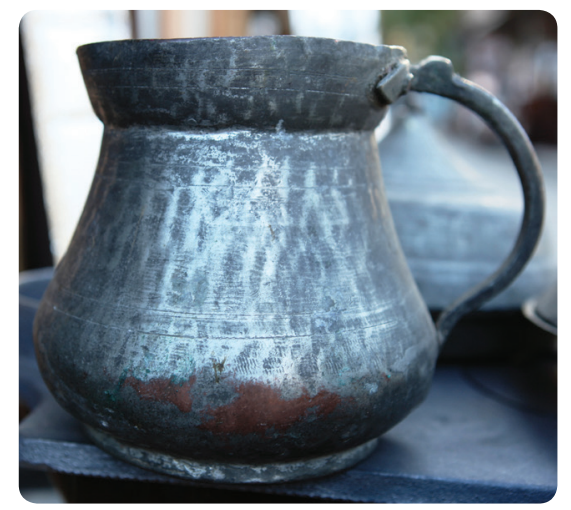

Resim 5. Kastamonu imalat maşrapa; Kastamonu yöresindeki adıyla "çöplük"17 (Kastamonu Bakırcılar ÇarşıII).

\subsection{Türk Hamamlarında Geleneksel Külhan} Donanımı ve Külhan Kazanları

"Hamamların içini ve suyunu ısıtan, kapalı ve geniş ocak" şeklinde tanımlayabileceğimiz kül17 Kastamonu kalay ustası Raşit Yazıcı (62) ile kişisel görüşme. 
han, hamamın ısıtma merkezidir. Burada ateşlik, soğuk ve sıcak su depoları bulunur. Genellikle sıcaklığın bitişiğinde su deposunun altında, hamamın döşemesinden daha düşük kotta bulunan külhanda ısıtma, ateşlikte yakılan odun ateşiyle sağlanır. Ateş, su deposu duvarının alt seviyesindeki bir kemer açıklığı vasıtasıyla kazanın altında yakılır (Çakmak, 2002: 21) ve kazanın üstünde yer alan su deposundaki su ısıtılır (Şekil 1-2). Ateşlikte oluşan duman ve sıcak hava, hamamın soyunmalık haricindeki kesimlerin döşeme altında "cehennemlik" (hipocaust) denen özel galerilerde dolaştrılır ve tüteklik denen bacadan dışarı atılır (Aru, 1949: 35-36; Anonim, 1997b: 1075; Hasol, 1998: 287), (Şekil 1). Sıcak ve soğuk suyun gerekli yerlere ulaştırılması, duvar içlerine yerleştirilen toprak esaslı künklerle (pöhrenk) sağlanır. Bunlardan geçen sıcak su hamamın ısınmasına yardımcı olur. Böylece hamam hem zemin (cehennemlik) hem de duvar içlerinden ısıtılır. Su kütlesinin altına su sızdırmayacak şekilde yerleştirilen dairevî külhan kazanın iki yanında alçak birer duvar yer alır. Isınan su yükselirken duvarlarda bırakılan menfezlerden soğuk su aşağıya akar. Sıcaklığa yönlendirilen sıcak suya mukabil menfezler aracılığıyla soğuk su deposundan gelen soğuk su, yanan ateşle birlikte ısıtılmaya devam eder. Külhan, ısınma haricinde, ayrıca hamamın suyunun depolanıp dağıtımının yapıldığı yeridir. ${ }^{18}$

Külhan kazanları su deposunun büyüklüğüne göre değişmekle birlikte bilinen örneklerden hareketle takriben 1-3 m. çapında dairevî büyük bakır kazanlardır. Büyüklüklerinden ötürü tek parçadan yapılmaları mümkün olmadığından perçin veya bakır kaynağıyla (kat lehim) birbirlerine tutturulan kalın bakır levhalardan yapılmışlardır (Önge, 1995: 45)..$^{19}$

18 Külhan donanımı hakkında ayrıca bkz. Aru (1949: 35-36); Önge (1988: 412); Önge (1995: 27-28, 44-46, 93); Çakmak (2002: 21-22); Ürer (2002: 5-6); Şehitoğlu (2008: 14-15).

19 "Külhandaki ocağın arkasına isabet eden depo zeminine, deponun büyüklüğüne göre çapları 90 ile $240 \mathrm{~cm}$. arasında

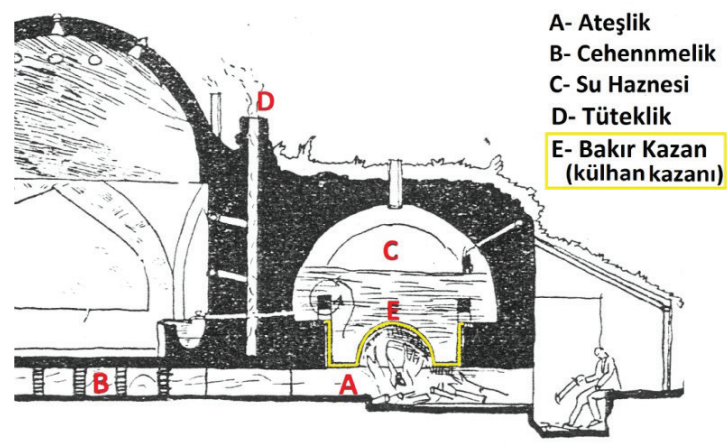

Şekil 1. Geleneksel hamam mimarimizde külhanın bölümleri ve külhan kazanının konumunu gösteren şematik çizim (Aru, 1949: 37).

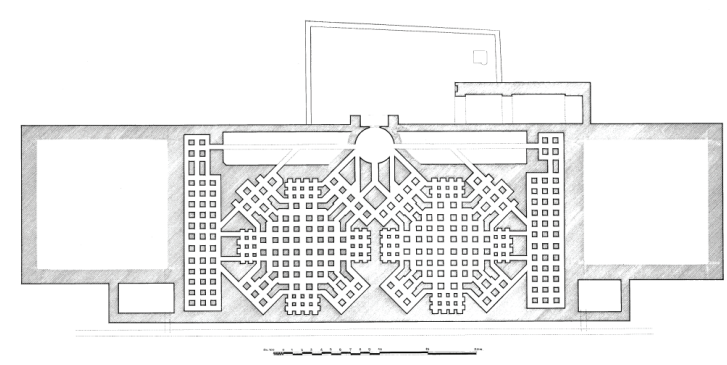

Şekil 2. İstanbul Çinili Hamam örneğinde cehennemlik katı planı (Ülgen 1989: levha 216).

değişen, daire plânlı bakır kazanlar gömülmüştür. Malzeme olarak dayanıksızlığı ve sık sık tamir edilme zarureti yüzünden, XI1-XIII. yüzyıllara ait orijinal bakır kazanlardan hiçbiri günümüze kadar gelememiştir. Harabe halindeki hamamlarda ise bunlar çalınmış olduğundan, ancak depo zeminindeki yuvaları görülmektedir. Daha sonraki yüzyıllarda Amasya'da XV. yüzyıla ait Mustafa Bey hamamının kazanı gibi bazı örneklerden, bu kazanların yekpare değil, iri çivilerle birbirine sıkıca perçinlenmiş, muhtelif kalın levhalardan meydana getirildiği belli olmaktadır. XII-XIII. yüzyıla ait bazı hamamlarda, büyük bakır kazanların su depolarına yerleştirilebilmeleri için tatbik edilmiş bir mimarî detay ilgi çekicidir. Hamamların inşası sırasında, su deposunun külhan cephesinde kazanın geçebileceği genişlikte ve yükseklikte kemerli bir boşluk, kazanın yerleştirilmesinden sonra bu boşluğun içine ince bir dolgu duvarı örülerek sadece külhan ocağının önünde küçük bir açıklık bırakılmaktadır. Tamir için gerektiğinde kazanın külhan tarafindan ve dolgu duvarını sökmek suretiyle dışarıya çıkartılmasını sağlayan bu detay, maalesef, sonraları metruk hamamların kazanlarını çalmak isteyen hırsızların da işine yaramıştı. Alanya İçkale Hamamı ile Aksaray Ağzıkara Han Köyünün Hamamları gibi. Sıcak su deposuna gelen soğuk suyun, ısındıktan sonra, deponun zeminine yakın bir seviyede ve sıcaklık duvarında yer alan borulardan, hamamın muhtelif hacımlarına sevkedildiği anlaşılmaktadır." (Önge, 1995: 45); "Hamam külhanlarında, sıcak su haznelerinin zemininde, alttan ateşin yandığı ocağın üstüne gelen yerde, hamam taslarına benzer 2-3 m. çapında kazanlar bulunmaktadır. Bunlar 3-4 mm. kalınlı̆ı̆ıda bakırdan yapılmıştır." (Tayla, 2007: 135). 


\section{Kastamonu'da Külhan Kazanları}

Kastamonu'da il merkezinde halka açık tarihî binalarda sergilenen üç tarihî hamam külhan kazanı bulunmaktadır (Resim 6-7).

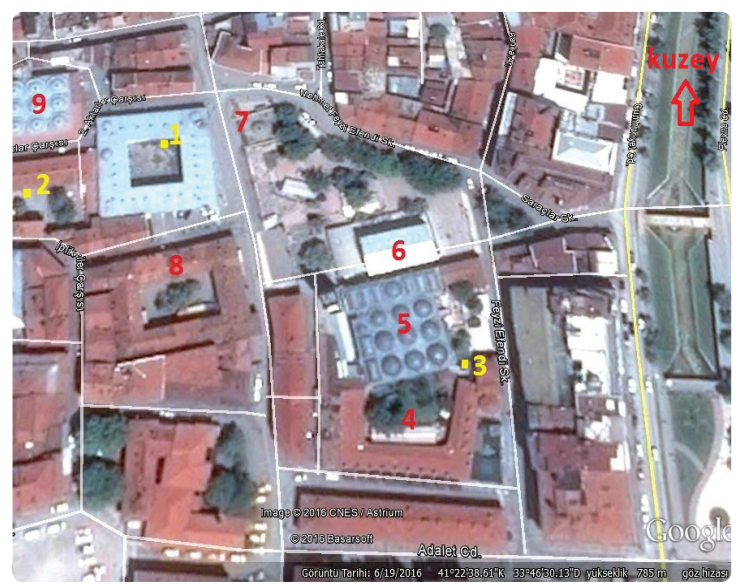

Resim 6. Kazanların sergilendiği yapılar ve yakın çevresinin uydu görünümü (Google Earth'den).

1- Kastamonu Vakıf Hamamı külhan kazanının bulunduğu kesim (sarı noktalı yer) ve İsmail Bey (Kurşunlu) Han. 2- Dede Sultan Hamamı külhan kazanının bulunduğu kesim ve Pembe (Balkapanı) Hanı. 3-Tosya Tekke Hamamı külhan kazanının bulunduğu kesim. 4- Münire Medresesi. 5- Nasrullah Paşa Camisi. 6- Nasrullah Paşa Camisi Şadırvanı. 7- Firenkşah Hamamı 8-Reisülküttap (Urgan) Hanı. 9-Karanlık Bedesten (Cem Sultan Bedesteni).

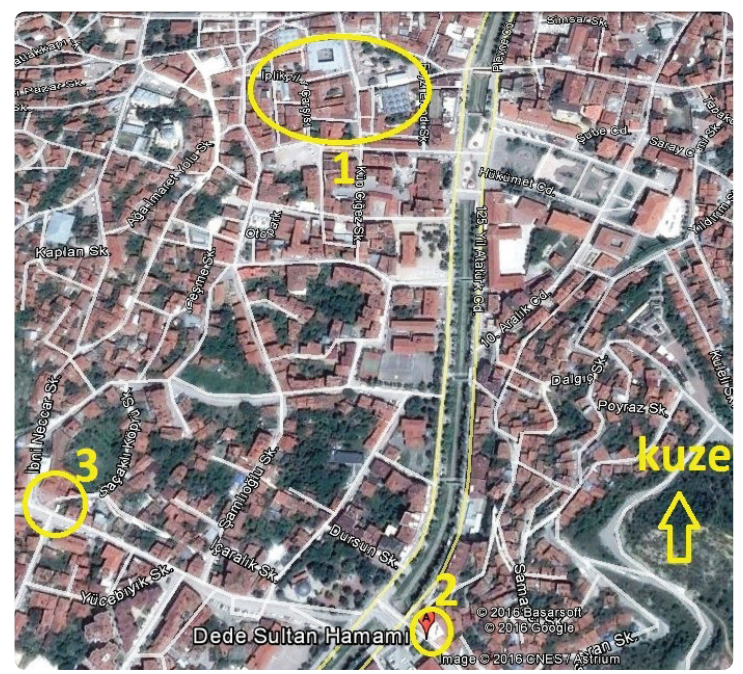

Resim 7. Kastamonu'daki kazanların ait olduğu hamamlar ve yakın çevresinin uydu görünümü (Google Earth'den). 1- Kazanların sergilendiği yapıların bulunduğu bölge. 2-Dede Sultan Hamamı civarı. 3- Vakıf Hamamı civarı.

\subsection{Kastamonu Vakıf Hamamı Külhan Kazanı}

Kazan, il merkezinde Hepkebirler Mahallesi'nde Nasrullah Camisi'nin ${ }^{20}$ bat yanında, sokak aşırı karşısında yer alan İsmail Bey (Kurşunlu) Hanı'nın ${ }^{21}$ zemin kat avlusunda bulunmaktadır (Resim 8-10). Üzerindeki 35x25 cm. ölçülerindeki yeni metal levhada da belirtildiği üzere kazan, İbni Neccar Mahallesi'nde bulunan Vakıf Hamamı'na aittir. Kazan, hamamından, Vakıflar Bölge Müdürlüğü tarafindan 2009 yılında alınarak, ${ }^{22}$ İsmail Bey Hanı'na getirilmiş ve bugünkü yerinde metal yeni bir kaide üzerinde sergilenilmeye başlanılmıştır.

Kazanın ait olduğu Vakıf Hamamı Kastamonu'nun en eski hamamlarından biridir (Resim 9). İbnineccar Sokak'ta, kuzeybat köşesi İbni Neccar Camisi'ne bitişik bulunan yapı, 127374 yılına tarihlenen Atabey Gazi Camisi'nin vakfindandır ve büyük bir intimalle Çobanoguulları'ndan Muzafferuddin Yavlak Arslan tarafindan 1273-1274 dolayında yaptırılmıştır (Gökoğlu, 1952: 363; Bilici, 1991: 192; Önge, 1995: 256; Eyüpgiller, 1999: 65, 67) $)^{23}$ 17221723 yılında yapının onarım gerektirecek bir halde olduğu, 1899-1900 yılında yine harap

20 Şehirdeki en büyük Osmanlı Camisi olan yapı, tarihî dokunun merkezinde yer almaktadır. 1506-1507 yılında Nasrullah el-Kadı bin Yusuf tarafindan ulu cami tipinde yaptrılan cami, 1746 yılında tamir ve yenileme ile genişletilmiş ve inşası ile birlikte zamanla etrafinda büyük bir külliye oluşmuştur (Gökoğlu, 1952: 203-207; Eyüpgiller, 1999: 102-103, 136-140, 148-149; Karakaya, 2006: 424-425).

21 Candaroğlu ìsmail Bey'in 1460-1461 tarihli vakfiyesinde yer alan yapı, vakfiye tarihi olan 1460 yılı dolaylarında ismi geçen İsmail Bey tarafindan yaptrılmıştır. Yapı tek avlulu iki katlı bir şehir hanıdır. 1972 ve son olarak kapsamlı bir şekilde 2008 yılında Vakıflar Genel Müdürlüğü tarafindan restore edilen ve butik otel olarak kullanılan yapı, bakımlı vaziyettedir (Gökoğlu, 1952: 349-350; Bilici, 1991: 116-119; Çifci, 1995: 269-270; Eyüpgiller, 1999: 76; Arslan, 2012: 267).

22 Bu ve diğer kazanların taşınma tarihleriyle ilintili bilgileri, taşınma işini vaktiyle organize eden Kastamonu Vakıflar Bölge Müdürü Sayın Yavuz Yücebıyık beyefendiden öğrendik. Kendilerine araştırmamız için gösterdiği kolaylıklar ve verdiği bilgiler için bir kez daha teşekkür ederiz.

23 Yapının tapu kayıtlarına göre Atabey Gazi Camisi'nin vakıflarından olduğu, banisinin ise Muzafferuddin Yavlak Arslan'ın dedesi ve Çobanoğulları Beyliği'nin kurucusu Hüsameddin Çoban Bey olabileceği yönünde farklı bir görüş de bulunmaktadır (Çif̧̧i, 1995: 283). 
olduğu ve bu yıllarda onarıldığı anlaşılmaktadır (Eyüpgiller, 1999: 67). Eyüpgiller'e göre hamamın mimarisi 13. yüzyıl izleri taşımakta ancak geçirdiği onarımlarla köklü değişikliklere uğramış, sıcaklık mekân düzeninin işaret ettiği üzere bugünkü görünümünü 15-17. yüzyıllar arasında almış olmalıdır. ${ }^{24} 1995$ yılı dolaylarında harap vaziyetteki yapı 2014 yılında Vakıflar Genel Müdürlüğü tarafindan restore edilmiştir. Kısa bir süre Kastamonu'nun çeşitli ilçelerinden getirilen etnoğrafik malzemelerin sergilendiği ve bu şekilde bir işlev kazandırılan bina, belirtilen işletmenin devamı sürdürülemediğinden, şimdilerde kapalı tutulmaktadır. Hamamın külhan kısmı günümüze gelememiştir. Kazanın iç yüzüne yapıştırılmış halde yeni bir metal levha bulunmaktadır (Resim 11). Levhada "Bu Hamam Kazanı 13. Yüzyılda Çobanoğulları Beyliği Döneminde İnşa Edilen Vakıf Hamamından Getirilmiştir. (Vakıf Hamamı Atabey Vakfina Aittir.) Vakıflar Genel Müdürlüğü" ifadeleri yazılıdır.

Kazan 0.4-0.5 cm. arasında değişen kalınlıktaki dört ayrı levhadan oluşmaktadır. Levhalar birbirlerine perçinlerle tutturulmuştur. Muntazam düzgün olmayan bir daire şeklindeki kazanın çapı, $189.5 \mathrm{~cm}$. ile $204.5 \mathrm{~cm}$. arasında değişmektedir. (Şekil 3, Resim 11-12). Zemine oturan dip (kaide) kesimi ortada yukarıya doğru $15 \mathrm{~cm}$. kadar bombe yaparak yükselmektedir (Şekil 4-6, Resim 13). Kazanın genelinde olduğu gibi yine tam daire şeklinde olmayan bu bombeli kesimin çapı, 114-129 cm. arasında değişmektedir.

24 Önge'nin değerlendirmelerine göre yapı 18. ve 19. yüzyıllarda önemli tadilat ve tamir görmüş olmalıdır (Önge, 1995: 256).
Kazanın kenarları (kasnak), tabandan 90lik bir açıyla dik olarak $37 \mathrm{~cm}$. yükselmekte ve yine aynı açıyla dışa dönük 6-7 cm. arasında değişen genişlikte bir ağız kenarıyla son bulmaktadır (Resim 14). Bombeli kesimin bitimi ile kasnak arasındaki mesafe (düztaban) $20-25 \mathrm{~cm}$. genişliğindedir. ${ }^{25}$

Kazanı oluşturan dört levhadan ikisi, tabanı oluşturmaktadır. Bu levhalar orta hizada $9 \mathrm{~cm}$. genişliğinde bir bant oluşturacak şekilde, birbirleri üzerine bindirilerek perçinlenmiştir (Resim 15-16). Perçin çivi başlarının çapları 1.3-1.6 $\mathrm{cm}$. arasında değişmektedir. Perçinler yan yana üçer olmak üzere düzgün sıralıdır (Şekil 3, Resim 15). Çoğu sağlam olmakla birlikte bazı perçinler dökülmüş haldedir. Kazanın ağız kenarı da dâhil olmak üzere kasnağı, iki büyük levhadan oluşmaktadır. Bu levhalarda hem birbirlerine, hem de taban levhalarına perçinlenerek birleştirilmiştir (Resim 14, 17).

Kazanın tabanına paralel uzanan düzgün bir hat oluşturan perçinler, diğer perçinli kesimlerde olduğu gibi, kazana ritmik tekrar esaslı dekoratif bir görünüm kazandırmıştır (Şekil 5, Resim 17). Kaide kesimindeki levhalar ile kasnak levhaları ortalama $6.5 \mathrm{~cm}$. kadar üst üste bindirilerek tek sıra halinde perçinlenmiştir.

Kasnak levhaları ise birbirlerine $9 \mathrm{~cm}$. kadar bindirilmiş ve iki sıra halinde ve karşılıklı şaşırtma sıralı perçinlenmiştir. Kazanın tamamında perçinlerin sık aralıklarla atıldıkları söylenebilir. Perçin arası mesafeler ortalama $2.5 \mathrm{~cm}$.dir.

Kazanın iç yüzüne perçinli hat boyunca kurşun dökülmüştür (Resim 17). Bunun ilk imalden sonraya ait olma intimali akla gelirse de kesin bir şey söylemek mümkün değildir.
25 Bombeli kesimin ve kazanın geneli tam yuvarlak biçimde olmadığından ölçü küçük farklılık gösteriyor. 


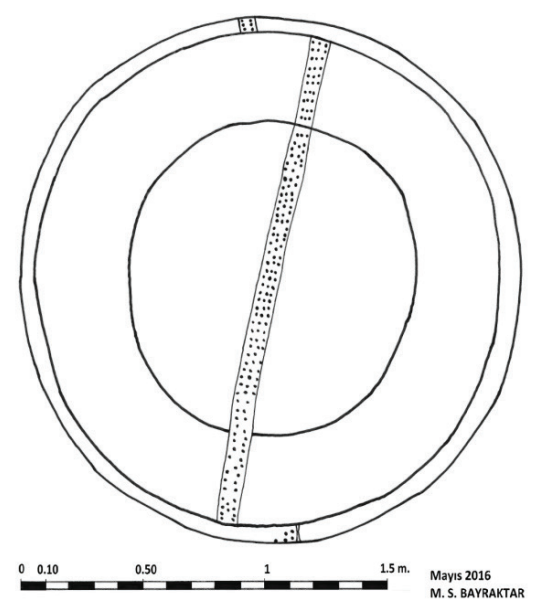

Şekil 3. Kastamonu Vakıf Hamamı külhan kazanı iç уӥzü cepheden görünüşü.

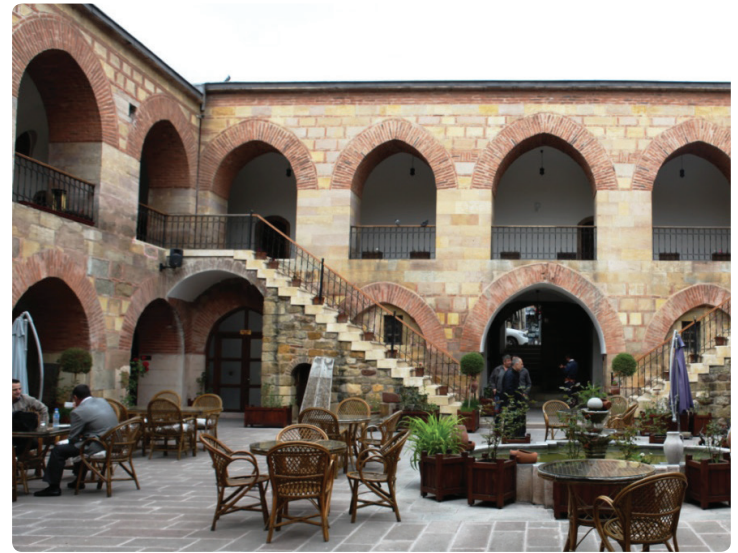

Resim 8. Kastamonu İsmail Bey (Kurşunlu) Hanı avlusu kuzey yüzü (Kastamonu Vakıf Hamamı külhan kazanının sergilendiği kesim).

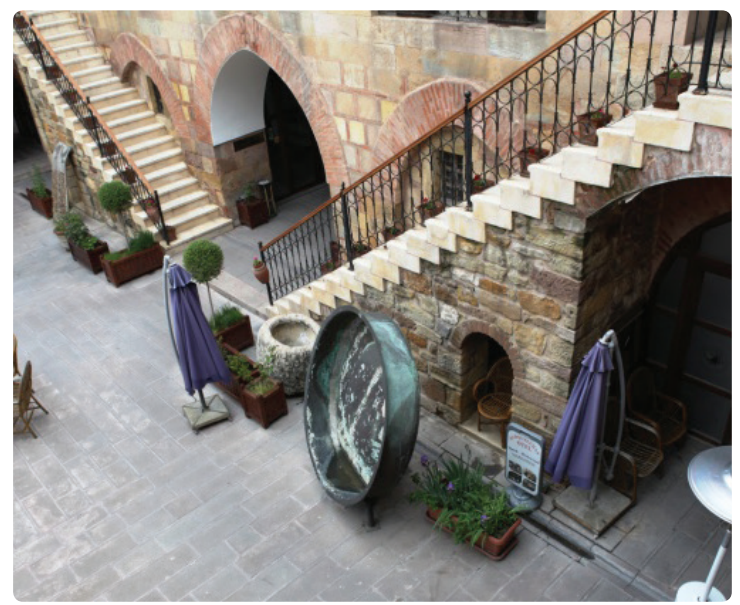

Resim 10. Kastamonu Ismail Bey (Kurşunlu) Hanı avlusunda Kastamonu Vakıf Hamamı külhan kazanına üstten bakış.
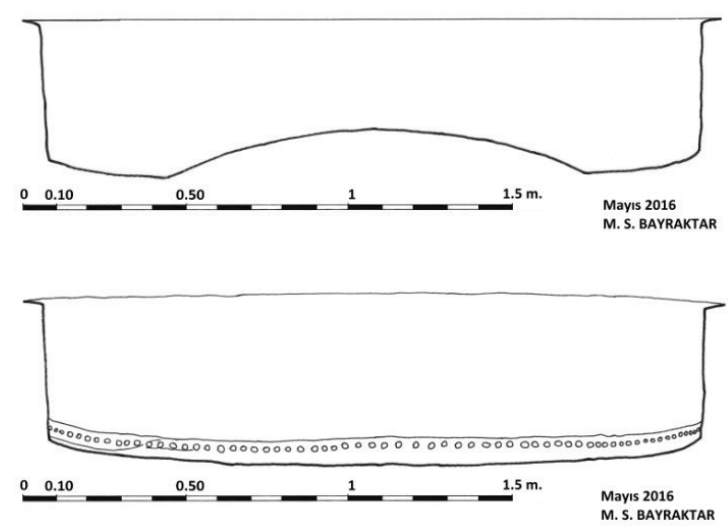

Şekil 4. Kastamonu Vakıf Hamamı külhan kazanı kesiti (üstte). Şekil 5. Kastamonu Vakıf Hamamı külhan kazanı dış yüz cephe görünüşü (altta).

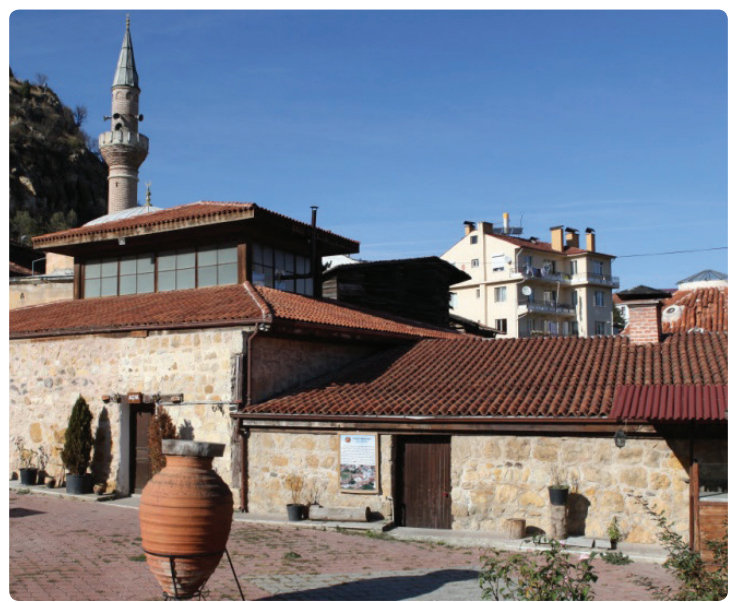

Resim 9. Kastamonu Vakıf Hamamı.

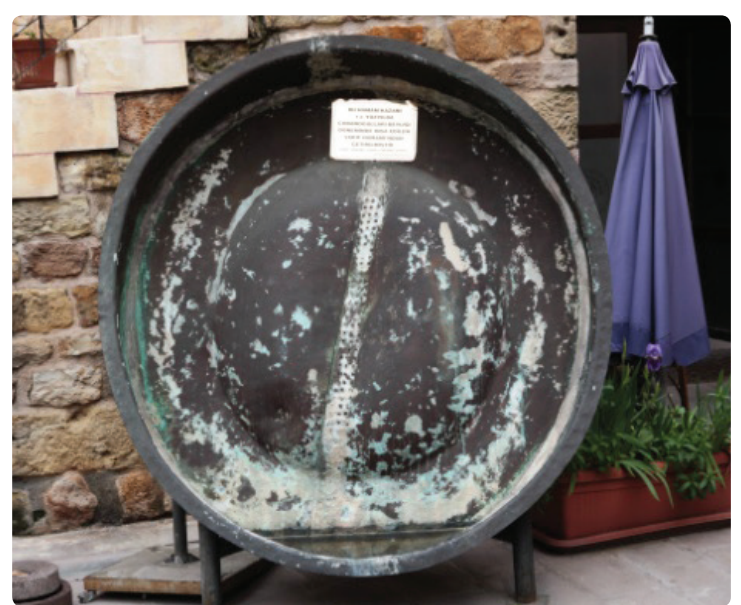

Resim 11. Kastamonu Vakıf Hamamı külhan kazanı iç yüzü. 


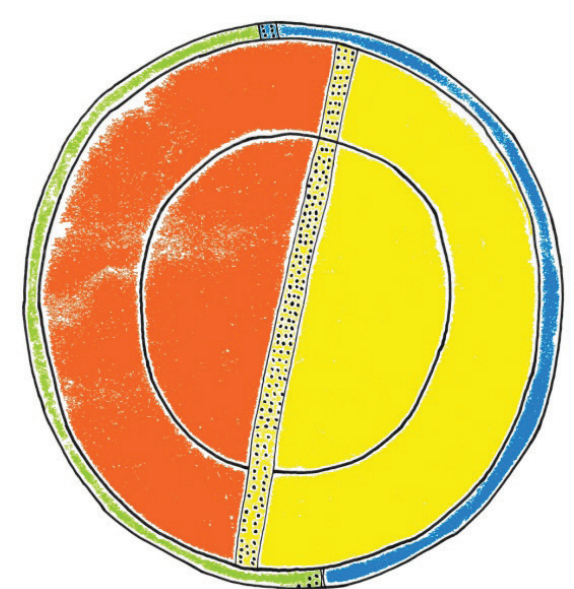

Şekil 6. Kastamonu Vakıf Hamamı külhan kazanı levhalarını gösterir şematik çizim. Taban levhaları: sarı ve turuncu. Kasnak levhaları: yeşil ve mavi.

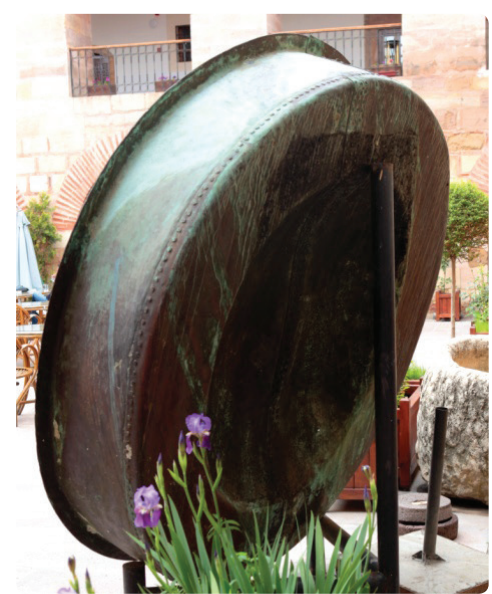

Resim 13. Kastamonu Vakıf Hamamı külhan kazanı dış yüzü (ateşe temas eden kesim).

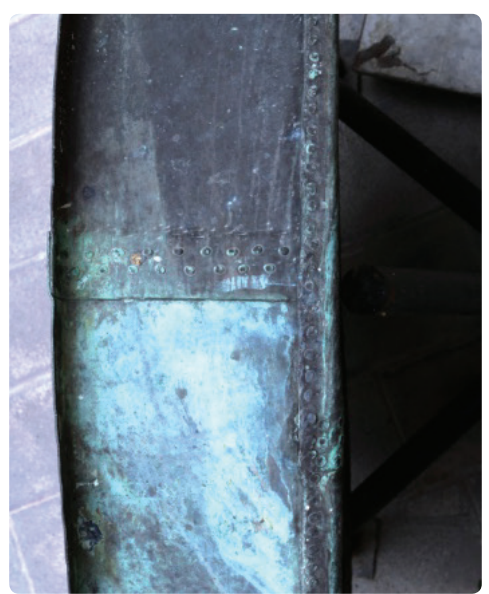

Resim 14. Kastamonu Vakıf Hamamı külhan kazanı kasnak (gövde) kesimi (üstten bakış).

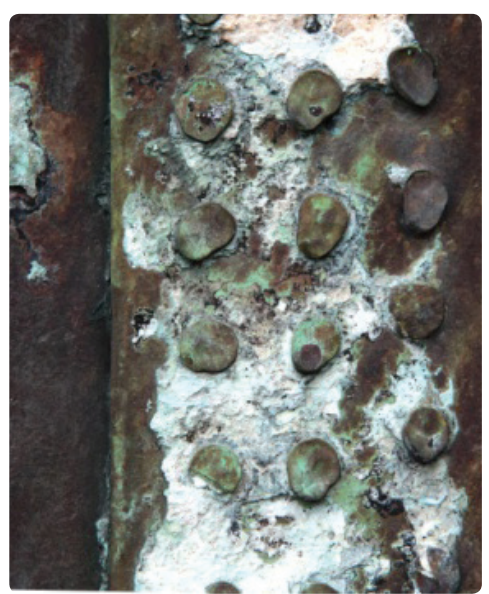

Resim 15. Kastamonu Vakıf Hamamı külhan kazanı perçin ayrıntısı (kazan tabanı iç yüz).

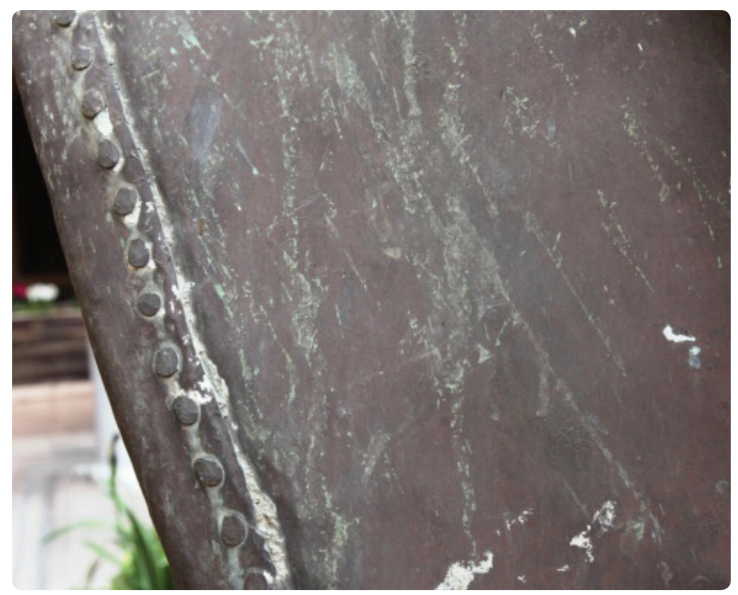

Resim 16. Kastamonu Vakıf Hamamı külhan kazanı dış yüzünden ayrınt;; dipte çivi perçinler, kasnak ve ağız kenarı kesimi.

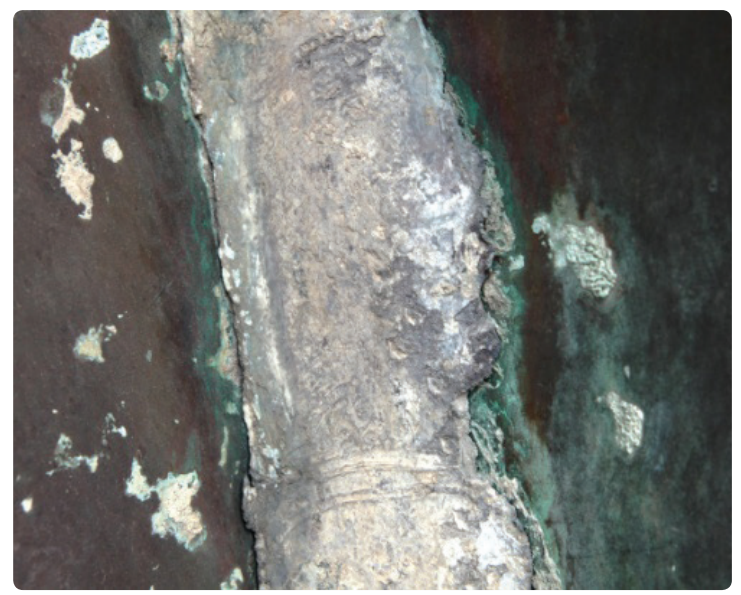

Resim 17. Kastamonu Vakıf Hamamı külhan kazanı iç taban kenarında perçinli kesim üzerindeki kurşun lehim (iç yüz). 


\subsection{Kastamonu Dede Sultan Hamamı Külhan Kazanı}

Kazan, Kastamonu il merkezinde Hepkebirler Mahallesi'nde İsmail Bey Hanı'nın batısında ve bitişiğinde yer alan Pembe (Balkapanı) Han'ın²6 zemin kat avlusunda bulunmaktadır (Resim 18). Üzerindeki $25 \times 15 \mathrm{~cm}$. ölçülerindeki yeni levhada da belirtildiği üzere kazan, Kastamonu il merkezindeki Dede Sultan Hamamı'ndan, Vakıflar Bölge Müdürlüğü tarafindan alınarak Pembe Han'a getirilmiştir (Resim 18-19). Kazan, 2015 yılından itibaren bugünkü yerinde metal yeni bir kaide üzerinde sergilenmektedir (Resim 20-23).

1514-1515 yılında Mevlevî Şeyhi Dede Sultan tarafindan yaptrilarak Mevlevihaneye vakfedilen (Gökoğlu, 1952: 366; Bilici 1991: 151-153; Eyüpgiller, 1999: 133) Dede Sultan Hamamı, İsfendiyar Mahallesi Tabaklar mevkiinde, Atatürk Caddesi üzerinde bulunmaktadır (Resim 19). Hamam işlevini sürdürürken 1675-1676 yılındaki bir depremde külhan, cehennemlik ve bazı kesimlerinin zarar gördüğü, 1766-1767 yılında kazan, kapı ve şadırvanının yenilendiği, bilahare 1948 ve 1985 yıllarında tekrar onarıldığı bildirilmektedir (Gökoğlu, 1952: 367; Eyüpgiller, 1999: 133). Yapı son olarak 2014 yılı civarında başlayıp birkaç yıl süren ve Vakıflar Genel Müdürlüğü tarafindan kapsamlı bir şekilde yaptırılan restorasyondan sonra işlev verilmeksizin kapalı tutulmaktadır.

Mevcut külhan kazanının 1766-67 yılındaki yenilenmeden kalma olduğu anlaşılmaktadır. Kazanın iç yüzüne yapıştırılmış yeni bir levha bulunmaktadır (Resim 20). Levhada "Kasta-

26 Halkın "Pembe" ve "Balkapanı" adlarıyla bildiği yapının vaktiyle "Urgan Hanı", "Pehbekapım Hanı", "Kapan Hanı" ve "Bayezid Kervansarayı" adlarıyla da bilindiği, yapının Sultan II. Bayezid Döneminde (1481-1512) "Harameyn" evkafi olarak yaptrıldığı belirtilmektedir (Gökoğlu, 1952: 351-352; Bilici, 1995; 380; Çifci, 1995: 273; Eyüpgiller, 1999: 127). 1995 yılı civarında harap haldeyken Vakıflar Genel Müdürlüğü tarafindan 2006 yılında restore edilen han, halen bakımlı bir haldedir. monu Merkez Dede Sultan Hamam Kazanı Bu Hamam Kazanı 1514 Yılında İnşa Edilen Dede Sultan Hamamından Getirilmiştir. (Dede Sultan Hamamı Dede Sultan Vakfina Aittir.) Vakıflar Genel Müdürlüğü" ifadeleri yazılıdır.

Kazan, 0.3-0.4 cm. arası değişen kalınlıkta ve birbirlerine perçinlerle tutturulan sekiz ayrı levhadan oluşmaktadır. Daire şeklindeki kazanın çapı $165 \mathrm{~cm}$. ile $166 \mathrm{~cm}$. arasında değişmektedir (Şekil 7-10, Resim 20).

Zemine oturan dip kesimi ortada yukarıya doğru $12 \mathrm{~cm}$. kadar bombe yaparak yükselmektedir (Şekil 7-9). Bombeli kesimin çapı 102-104 $\mathrm{cm}$. arasında değişmektedir. Kazanın kasnak kesimi tabandan 90이 bir açıyla dik olarak 32 $\mathrm{cm}$. yükselmekte ve dışa dönük 7-8 cm. arasında değişen genişlikte bir kenar ağız kenarıyla son bulmaktadır (Resim 21-23). Kazanın tabanı kimi kesimlerde tam düz olmayıp 5-6 cm. kadar dışa dönük bir çıkınt yapmaktadır (Resim 23). Bunun ilk imalden sonra tadilat sonucu oluştuğu anlaşılmaktadır. Zira bombenin olduğu kesimde şekli ve boyutu itibariyle bir tamir eseri olabileceği izlenimi veren yama şeklinde küçük bir levha bulunmaktadır (Şekil 10, Resim 21).

Kazan sekiz ayrı levhadan imal edilmiştir. Bunlardan dördü birbirlerine bakır kaynağıyla birleştirilerek tabanı oluşturmaktadır (Şekil 10, Resim 20). Bu üç levhadan diğerlerinden oldukça küçük olanı, yukarıda sözünü ettiğimiz tamir yamasıdır (Şekil 7, 10, Resim 21, 23). Bu parçayı hariç tutarsak aslî halde dip kesiminin üç parçadan oluştuğu söylenebilir. Kazanın taban haricinde kalan, kasnak ve ağız kenarı kısmı, dört levhadan oluşmaktadır. Bu levhalar, birbirlerine bakır kaynağıyla, taban levhalarına ise perçinlerle birleştirilmiştir (Resim 22-28). Levhaların birbirlerine birleştiği kesimleri dişli kesilmiş ve altlı-üstlü birbirlerine geçirilmişlerdir (Resim 26-31). Ayrıca su sızdırmaması için hat boyunca bakır kaynağı yapılmıştır (Resim 
26-31). Çivi perçinli kesimlerde, levhalar 4-5 $\mathrm{cm}$. kadar birbirleri üzerine bindirilerek tek sıra halinde perçinlenmiştir (Resim 25). Perçin çivileri başlarının çapları 1-1.4 cm. arasında değişmektedir. Çiviler sık aralıklarla atılmışlardır. Çivi arası mesafeler ortalama $2,5 \mathrm{~cm}$. civarındadır. Çoğu sağlam olmakla birlikte bazı perçin çivileri dökülmüştür. Perçinli hat boyunca kazan içi kesime kurşun dökülmüştür.

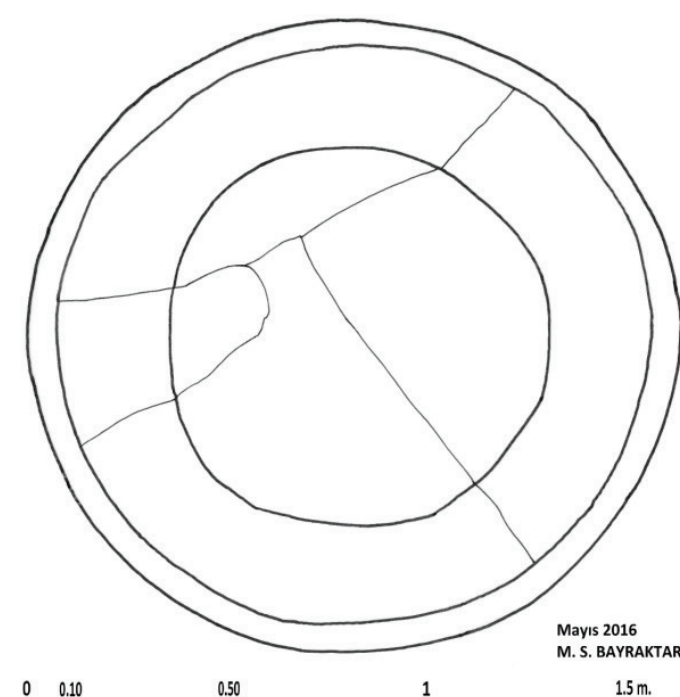

Şekil 7. Kastamonu Dede Sultan Hamamı külhan kazanı iç yüzü cephe görünüşü.
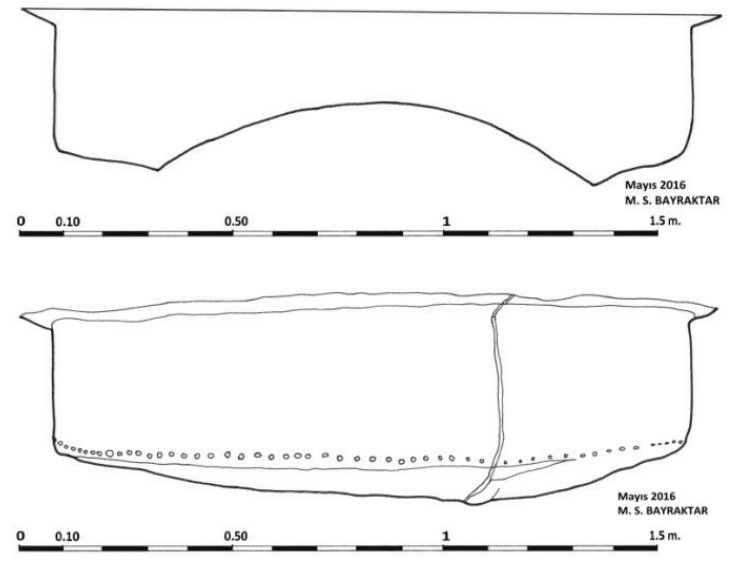

Şekil 8. Kastamonu Dede Sultan Hamamı külhan kazanı kesiti (üstte).

Şekil 9. Kastamonu Dede Sultan Hamamı külhan kazanı dış yüz cephe görünüşü (altta).

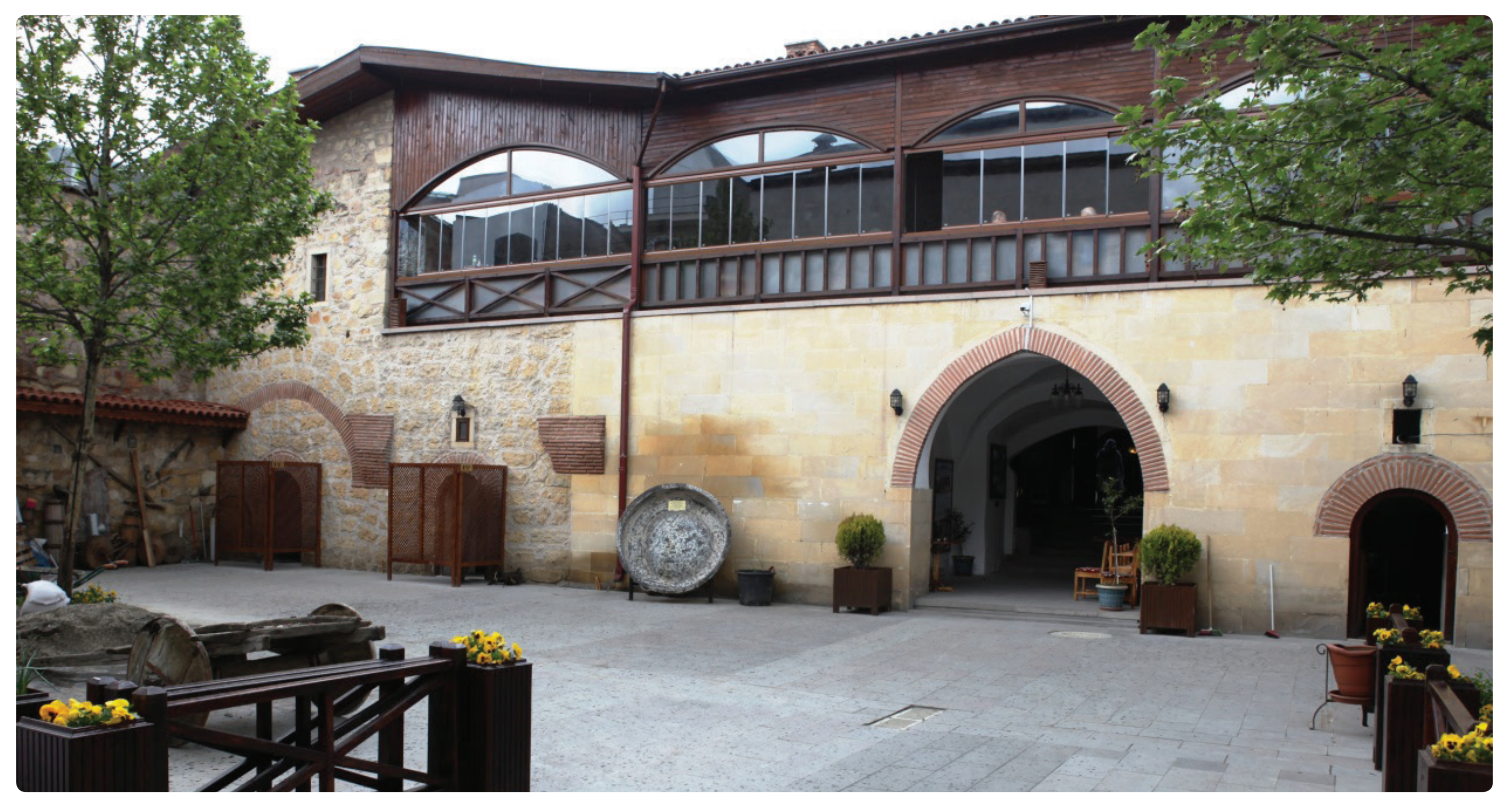

Resim 18. Kastamonu Pembe (Balkapanı) Hanı avlusu kuzey yüzü (Kastamonu Dede Sultan Hamamı külhan kazanının sergilendiği kesim). 


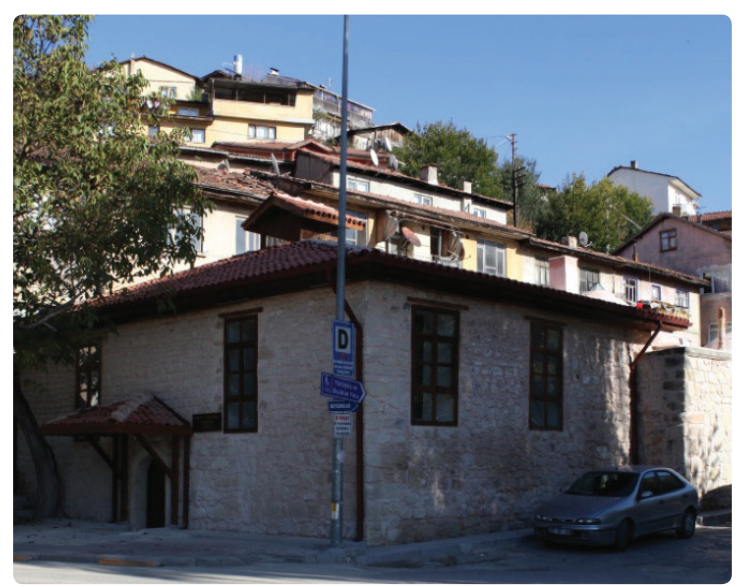

Resim 19. Kastamonu il merkezinde Dede Sultan Hamamı.

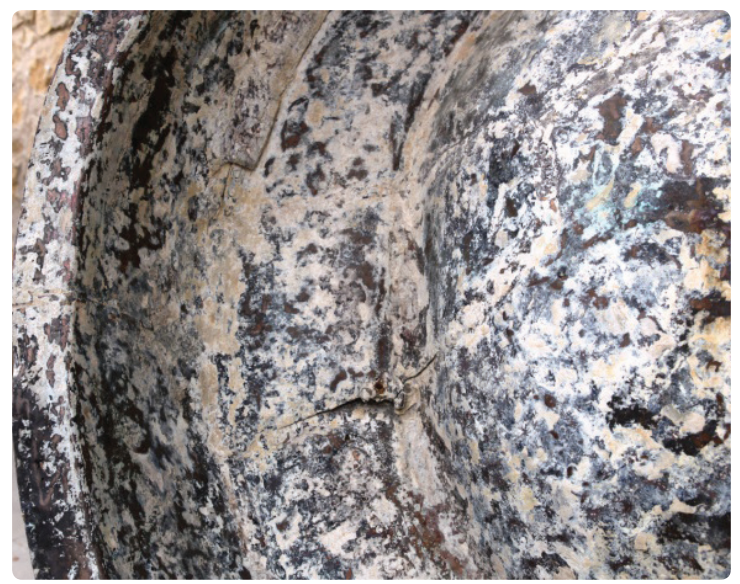

Resim 21. Kastamonu Dede Sultan Hamamı külhan kazanı iç yüz ayrıntısı (altta); tamir (yama) levhasının bulunduğu kesim ve yakın çevresi.

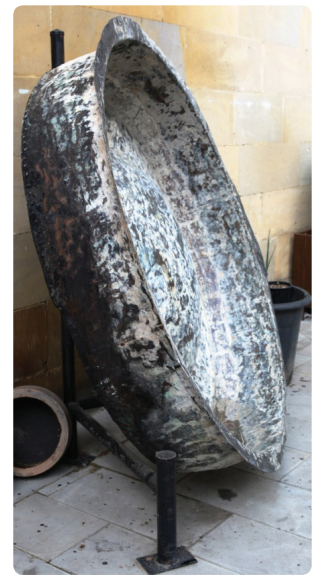

Resim 22. Kastamonu Dede Sultan Hamamı külhan kazanı.

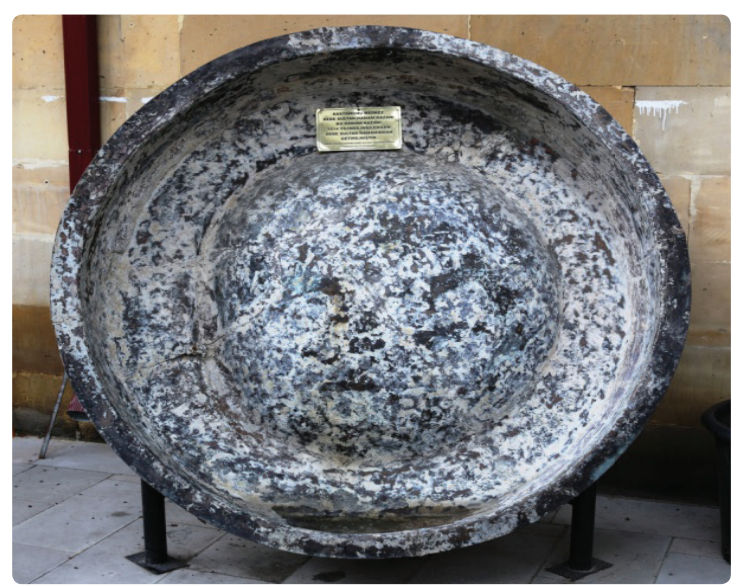

Resim 20. Kastamonu Dede Sultan Hamamı külhan kazanı iç yüzü.

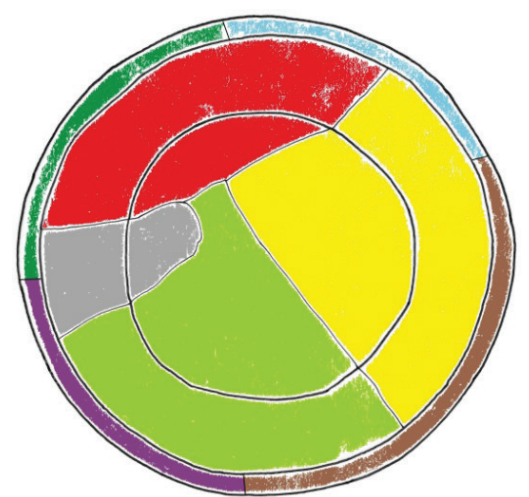

Şekil 10. Kastamonu Dede Sultan Hamamı külhan kazanı levhalarını gösterir şematik çizim. Taban levhaları: sarı, kırmızı açık yeşil ve gri (gri=tamir / yama levhası). Kasnak levhaları: mor, koyu yeşil, mavi ve kahverengi.

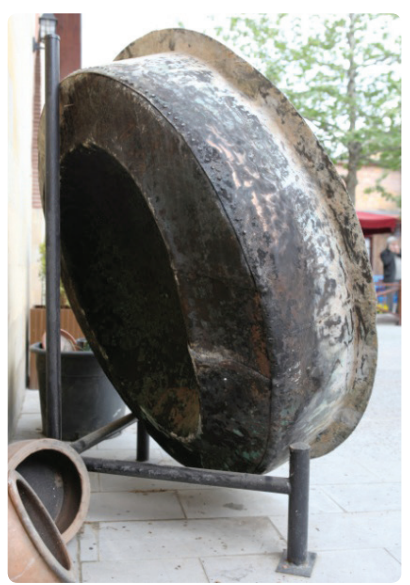

Resim 23. Kastamonu Dede Sultan Hamamı külhan kazanı dış yüzü (ateşe temas eden kesim). 


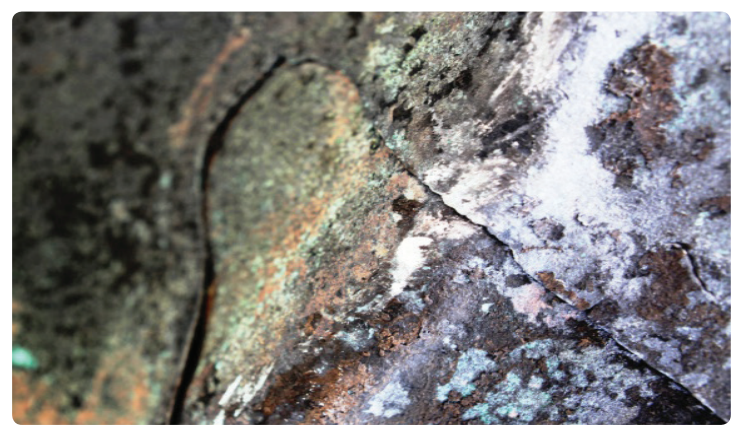

Resim 24. Kastamonu Dede Sultan Hamamı külhan kazanı dış yüzünden ayrınt; yama levhası.

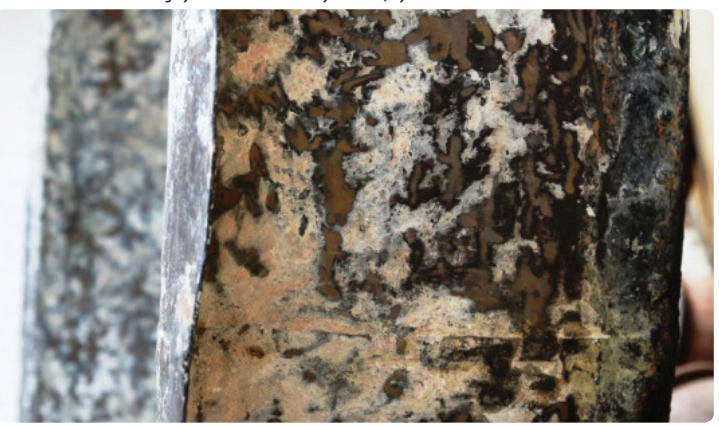

Resim 26. Kastamonu Dede Sultan Hamamı külhan kazanı dış yüzünden ayrınti; kasnakta dişler (çentik).

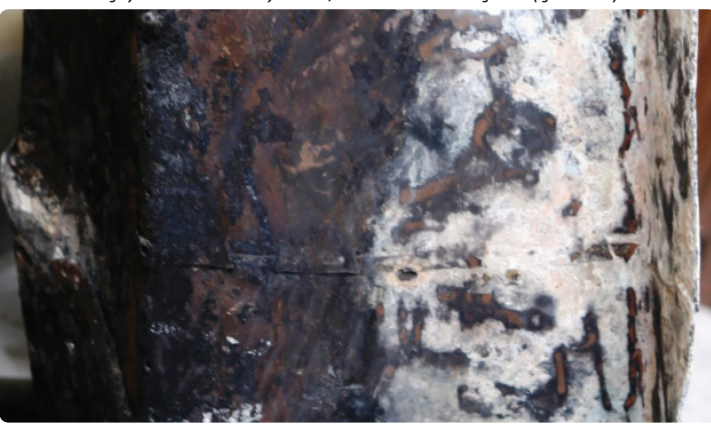

Resim 28. Kastamonu Dede Sultan Hamamı külhan kazanı dış yüzünden ayrınt; kasnakta dişler ve kaynak.

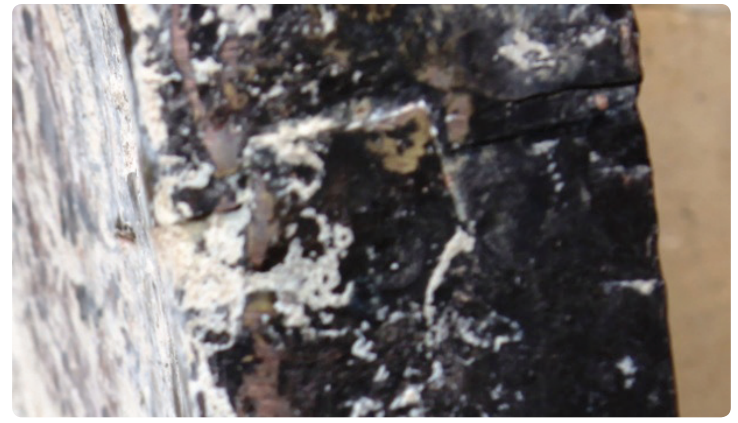

Resim 30. Kastamonu Dede Sultan Hamamı külhan kazanı ağız kenarı diş ayrıntısı.

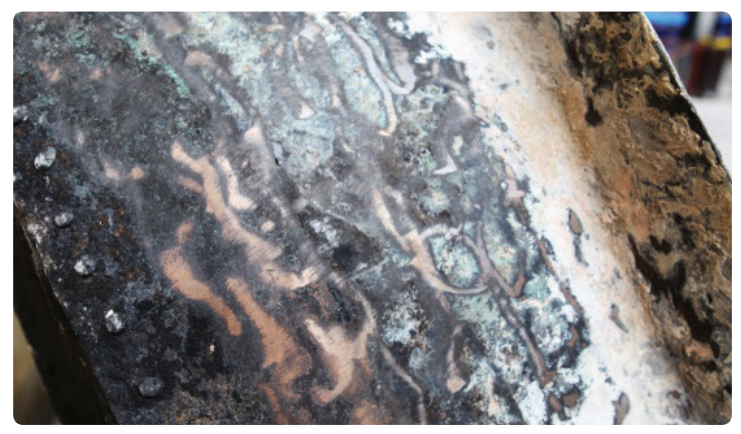

Resim 25. Kastamonu Dede Sultan Hamamı külhan kazanı dış yüzünden ayrınt;; kasnak.

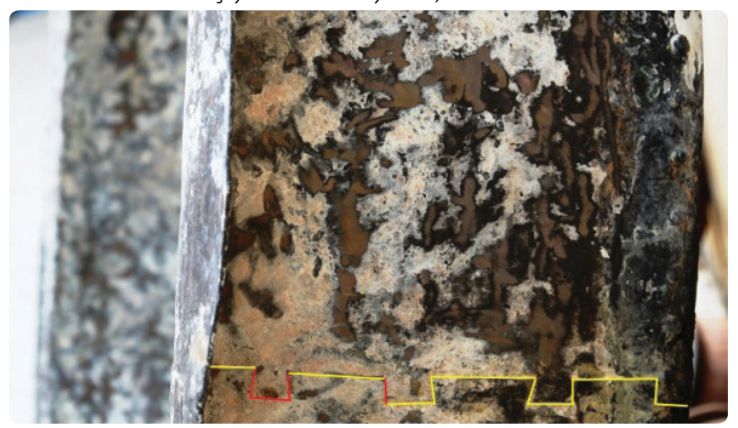

Resim 27. Kastamonu Dede Sultan Hamamı külhan kazanı dış yüzünden ayrınt; kasnakta dişlerin işaretlenmesi. ${ }^{27}$

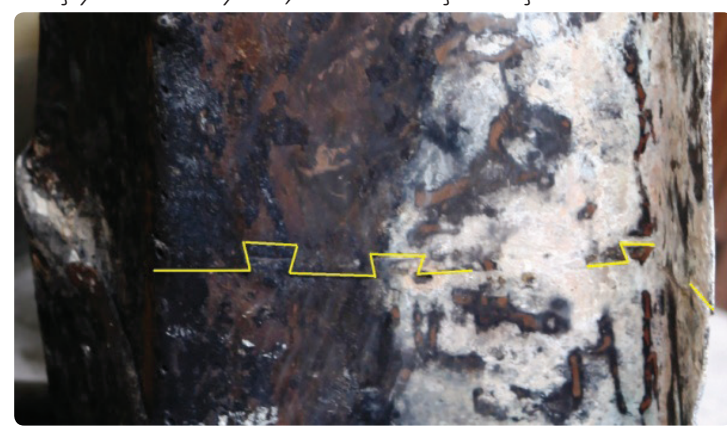

Resim 29. Kastamonu Dede Sultan Hamamı külhan kazanı dış yüzünden ayrınt; kasnakta dişlerin işaretlenmesi.

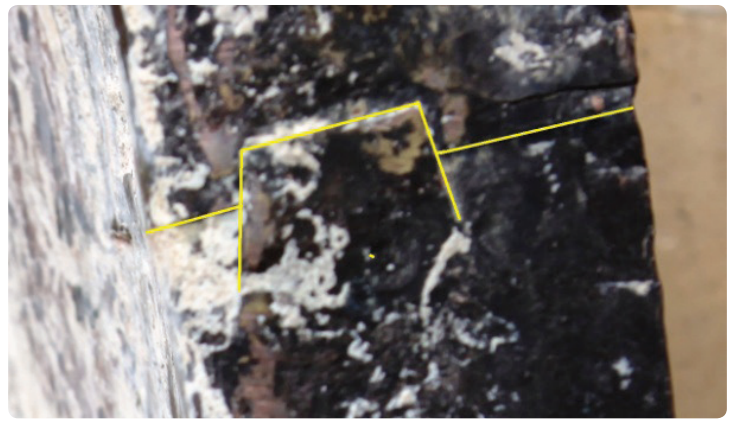

Resim 31. Kastamonu Dede Sultan Hamamı külhan kazanı ağız kenarı dişlerin işaretlenmesi.

27 Sarı renk tespit edilebilen kesimleri, kırmızı renk ise yüzeydeki muhdes harç izleri sebebiyle net görülemeyen fakat tahmin yürütülebilecek kesimleri göstermektedir. 


\subsection{Tosya Tekke Hamamı Külhan Kazanı}

Kazan, Kastamonu il merkezinde Hepkebirler Mahallesi'nde, Nasrullah Paşa Camisi'nin kıble tarafinda, avlu duvarının dış yanı başında, Münire Medresesiं ${ }^{28}$ avlusunun kuzey doğu köşesinde bulunmaktadır (Resim 32). Üzerindeki $25 \times 15 \mathrm{~cm}$. ölçüsündeki yeni metal levhada da belirtildiği üzere kazan, Kastamonu'ya bağlı Tosya ilçe merkezinde Hocaimat Mahallesi'nde bulunan Tekke Hamamı'ndan, 2002 tarihinde Vakıflar Bölge Müdürlüğü tarafindan alınarak bu günkü yerine taşınmış metal yeni bir kaide üzerinde sergilenmektedir (Resim 33-34).

Tekke Hamamı́nın 1637 yılında vefat ettiği ileri sürülen Şeyh İsmaili Rumi tarafindan yaptırıldığı belirtilmektedir (Gökoğlu, 1952: 374). Dolayısıyla hamamın 1637 yılından birkaç yıl önce inşa edilmiş olabileceğini varsayabiliriz. 25 Şubat 2014 yılında hamamının kazan dairesinde meydana gelen yangında kazan dairesi hasar görmüş ancak yangın fazla büyümeden söndürülmüştür. ${ }^{29}$

Kazanın iç yüzüne yapıştrılmış halde metal yeni bir levha bulunmaktadır (Resim 34,39). Levhada, ardında İngilizcesiyle birlikte "Kastamonu Tosya Tekke Hamamı Kazanı (Osmanlı Dönemi) Vakıflar Genel Müdürlüğü" ifadeleri yazılıdır.

Kazan 0.3-0.7 cm. arasında değişen kalınlıkta birbirlerine perçinlerle tutturulan 12 ayrı levhadan oluşmaktadır (Şekil 11, Resim 34). Zemine oturan dip kesimi ortada yukarıya doğru $34 \mathrm{~cm}$. kadar bombe yaparak yükselmektedir (Şekil 12-13). Kazanın ortasındaki $58 \times 58.5 \mathrm{~cm}$. çapında düz bir levha, bu bombeli kısmın üst noktasını oluşturur. Bu levhanın etrafinı çepeçevre saran diğer dokuz levha, kaideye doğru

28 "Reis'ül-Küttab Hacı Mustafa Efendi" ve "Bayraklı" adlarıyla da bilinen "Münire Medresesi", üzerindeki kitabesine göre Reisü'I-Küttab Hacı Mustafa Efendi tarafindan1746 yılında yaptrıımıştır (Gökoğlu, 1952: 344; Bilici, 1991: 86-89).

29 http://www.tosyahaberleri.com/asayis/tarihi-tekke-hamaminda-yangin-h4726.html önce içe sonra yine hafifçe dışa dönük olarak devam ederek kazanın dip kısmını tamamlar (Şekil 12-13, Resim 34-38). Kazanın kasnağı oluşturan iki ayrı levha, bu dokuz levhanın bitiminde başlayıp kazanın dış çeperini tamamlar (Resim 35-37). Levha kalınlığı bakımından da bu kesimdeki iki levha diğer levhalardan daha incedir. Levha kalınlığı burada $0.3-0.5 \mathrm{~cm}$. arasında iken diğerlerinde $0.5-0.7 \mathrm{~cm}$. arasındadır. Bu iki levhanın şekli muntazam değildir. İçe doğru gayri muntazam bükülen levhalarda yer yer kesik ve tahribat izleri görülmektedir. Ne kadar uzandıkları belli olmadığından kazanın derinliğini tespit etmek mümkün olmamıştir (Şekil 12-13, Resim 36-37). Diğer kazanlarda görmeye alıştğımız; bir ağız kenarıyla son bulan düzgün bir kasnağa sahip olmayan kazanın bu halini izahta güçlük çekmekteyiz. Muhtemel bir tadilatın veya kazanın hamamdan alınması sırasında meydana gelen tahribatin sebep olabileceği akla gelmektedir. Özellikle kullanılmayan veya metruk hale gelen hamamlarda değerinden ötürü bakır külhan kazanlarının çalındığı bilinen bir husustur.

Diğer iki kazanda görülen tabandaki bombe, bu kazanda da görülmektedir. Ancak imal yöntemleri farklıdır. Diğerlerinde bombeyi oluşturan levhalar dövülerek bombeli biçim sağlanmış ve levhalar birbirlerine bakır kaynağıyla birleştirilmiştir. Bu kazanda ise yukarıda da değindiğimiz üzere ortaya düz bir levha konulmuş ve etrafi perçinlerle birleştirilen levhalarla sarılmış ve bombeli biçim elde edilmiştir. Diğerlerinde bombeli kesimin merkezi yay biçiminde küresel bir kesit/eğri verirken, burada orta kesim düz, bombenin etrafi eğri biçim vermektedir.

Kazanın taban ve kasnaktaki tüm levhaları birbirleri üzerine bindirilmiş ve perçinlerle birleştirilmişlerdir (Resim 38-43). Tabandaki perçinler belli aralıklarla düzgün sıralar meydana getirir (Resim 38-40). Bazı yerlerde levhalarda meydana gelen yırttk ve çatlaklar için, düzgün 
sıralılardan hariç tamir maksatlı perçinler görülür (Resim 39-40). Perçin çivileri başları büyüklük itibariyle iki gruptur. Taban levhasına bitişik levhaların kenarı boyunca uzanan perçin çivi başları büyük, diğerleri küçüktür (Resim 3840). Çap ölçüleri, küçüklerde 1.5-1.9 cm., büyüklerde $4.5-5.2 \mathrm{~cm}$. arasında değişmektedir. Çoğu sağlam olmakla birlikte bazı perçin çivileri dökülmüştür. Kazanın tamamında perçinlerin sık aralıklarla atıldıkları söylenebilir. Kısmen ritmik tekrar esaslı perçinler, kazana dekoratif

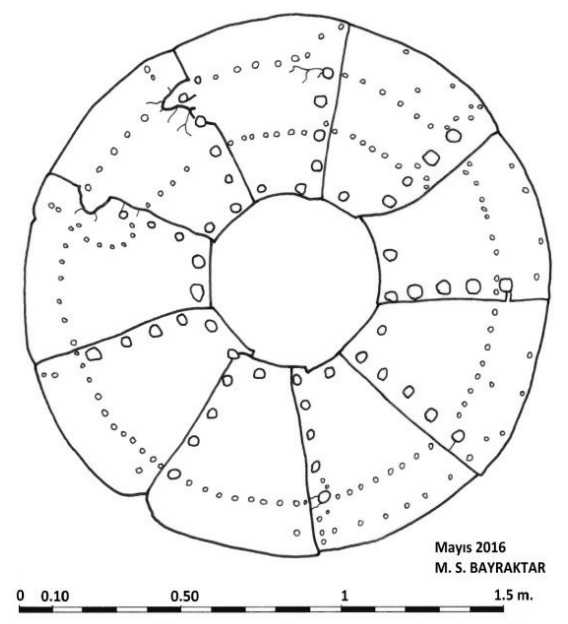

Şekil 11. Tosya Tekke Hamamı külhan kazanı dış yüzü cephe görünüşü. bir görünüm kazandırmıştır. Perçinlerin bazıları yeni; vidalı perçinlerdir ki yakın zamanlara ait bir tamirle irtibatlı olmalıdır.

Kazanın suyun dolduğu iç kesiminde bugün yılların biriktirdiği sudan kaynaklanan bir kireç tabakası ve bakır yüzeyi kaplayan bakıra has yeşilimsi renk alan oksitlenme görülmektedir (Resim 43). Kireç tabakası, levhaların birbirlerine bindirme yapan aralarında da mevcuttur (Resim 41).

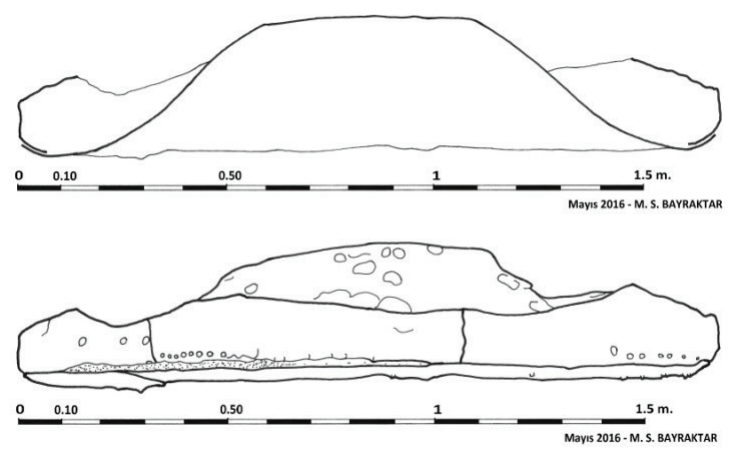

Şekil 12. Tosya Tekke Hamamı külhan kazanı kesiti (üstte).

Şekil 13. Tosya Tekke Hamamı külhan kazanı dış yüz cephe görünüşü (altta).

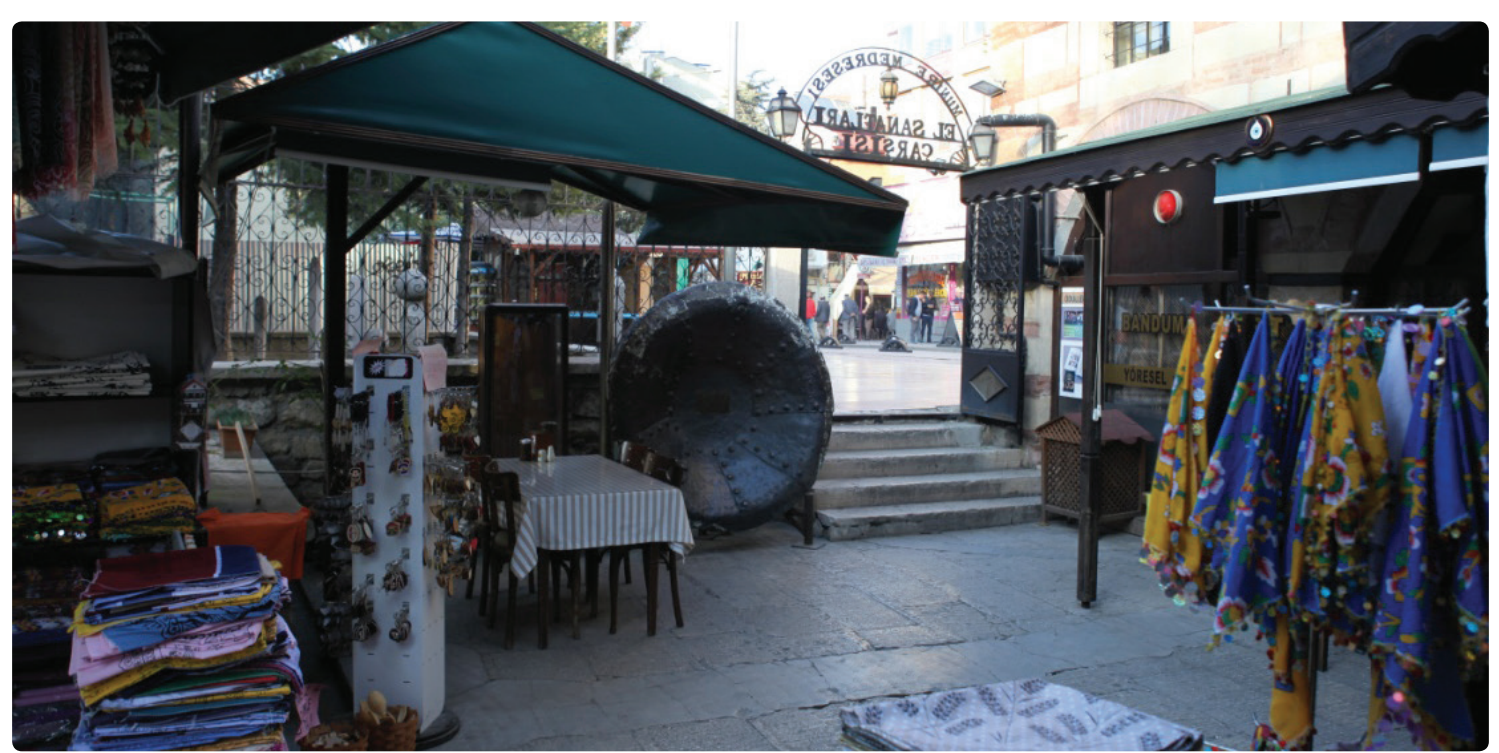

Resim 32. Kastamonu - Tosya Tekke Hamamı külhan kazanı ve sergilendiği alan. 


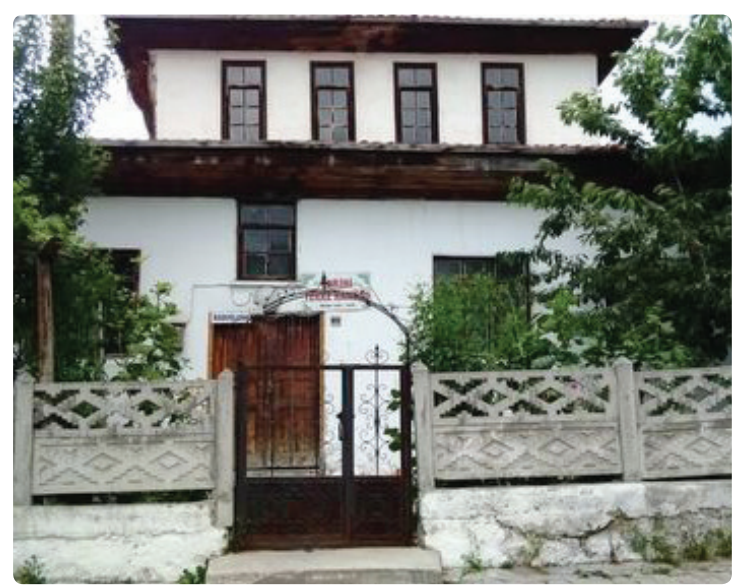

Resim 33. Kastamonu - Tosya Tekke Hamamı. (http://tosyatekkehamam.tr.gg/)

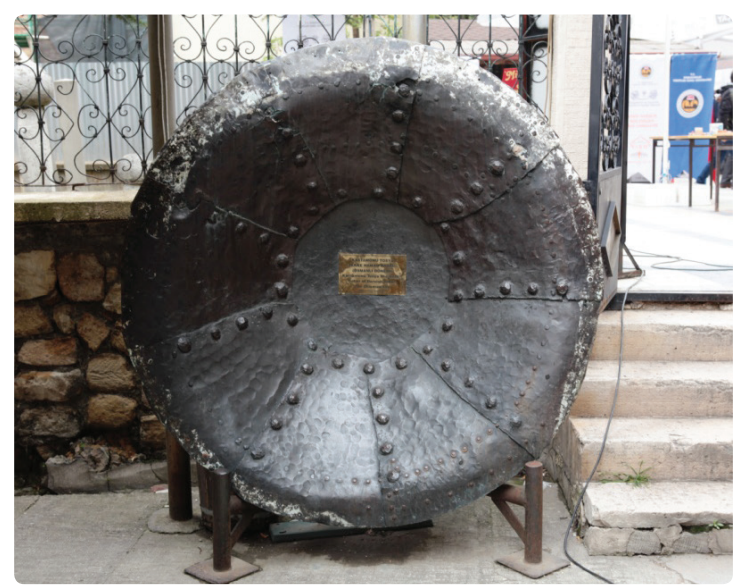

Resim 34. Tosya Tekke Hamamı külhan kazanı dış yüzü (ateşe temas eden kesim).

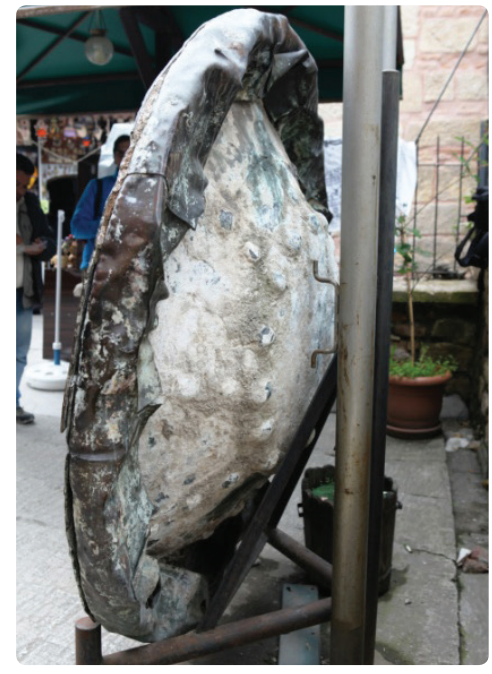

Resim 35. Tosya Tekke Hamamı külhan kazanı iç yüzü.

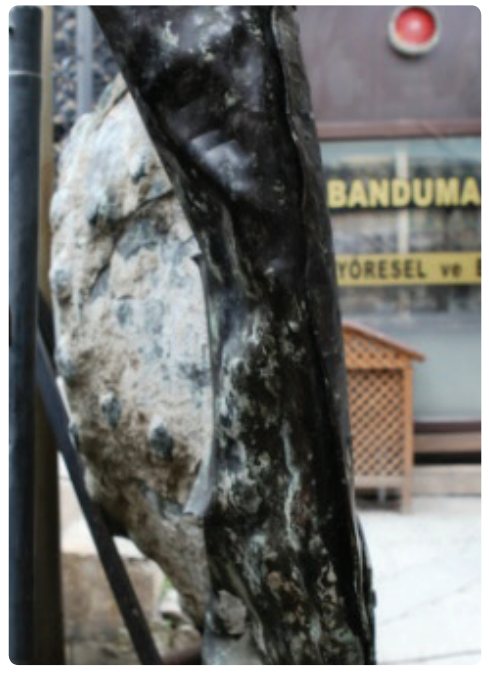

Resim 36. Tosya Tekke Hamamı külhan kazanı yandan görünüş.

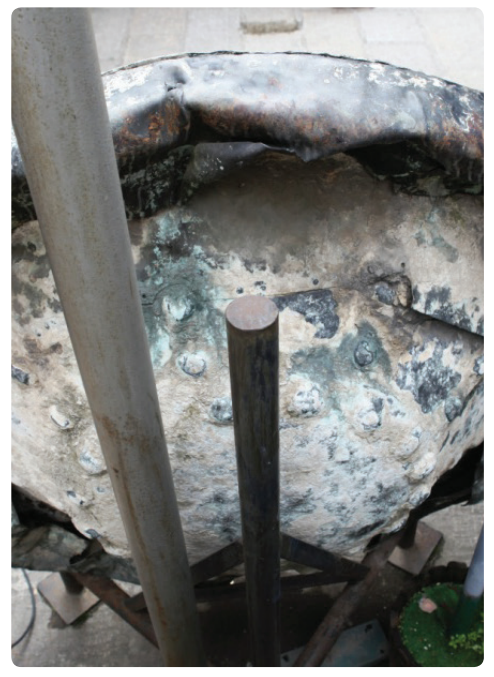

Resim 37. Tosya Tekke Hamamı külhan kazanı iç yüz.

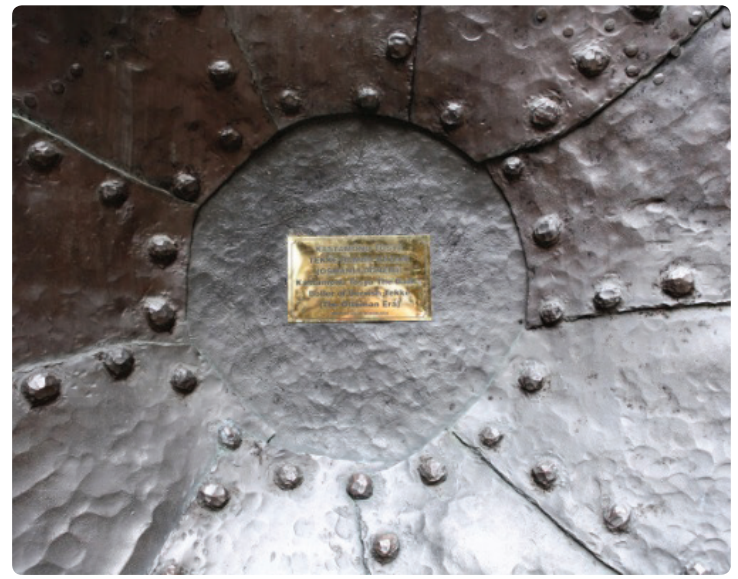

Resim 38. Tosya Tekke Hamamı külhan kazanı dış yüzü taban levhası ve çevresi.

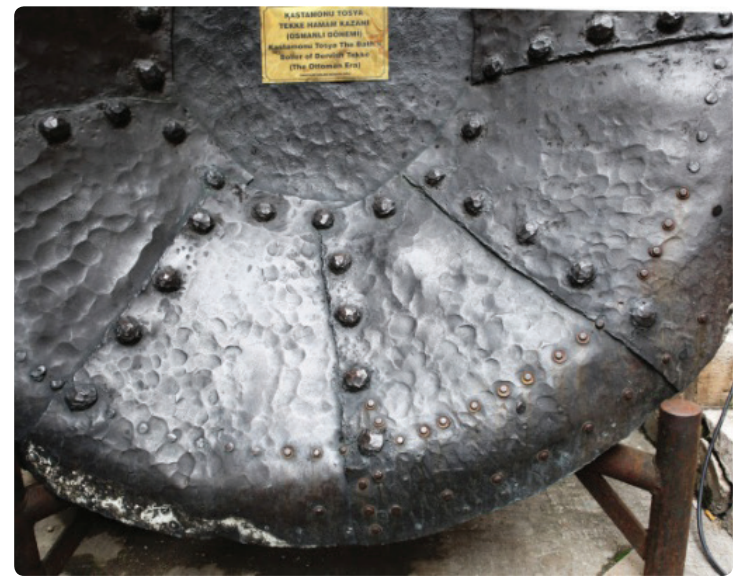

Resim 39. Tosya Tekke Hamamı külhan kazanı dış yüzünden ayrınt. 


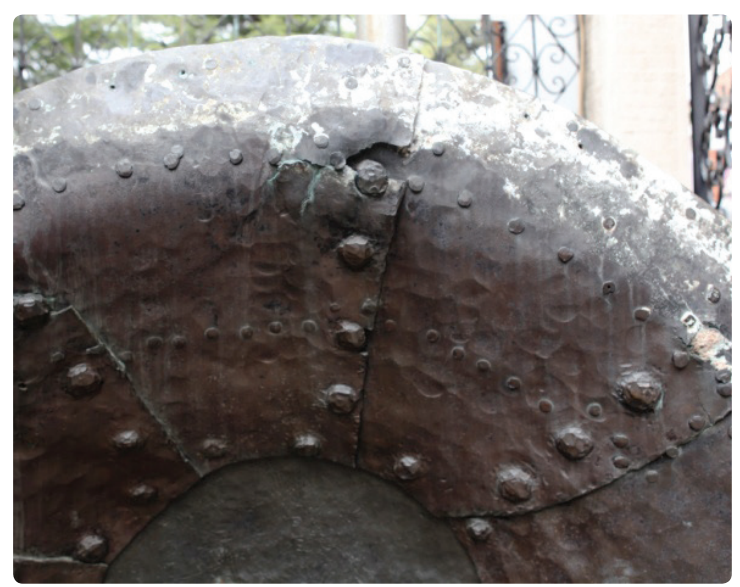

Resim 40. Tosya Tekke Hamamı külhan kazanı dış yüzünden ayrınt.

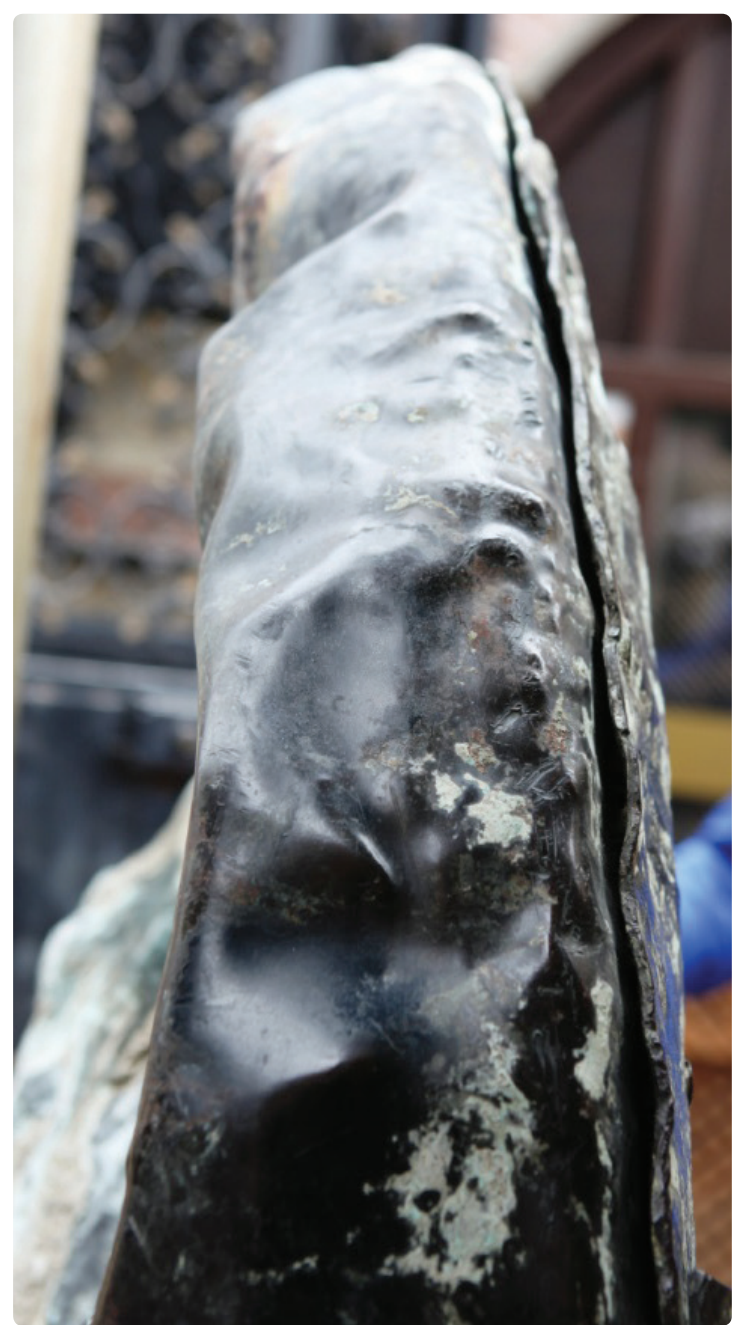

Resim 42. Tosya Tekke Hamamı külhan kazanı dış yüzünden ayrınt;; kasnak (yandan bakış).

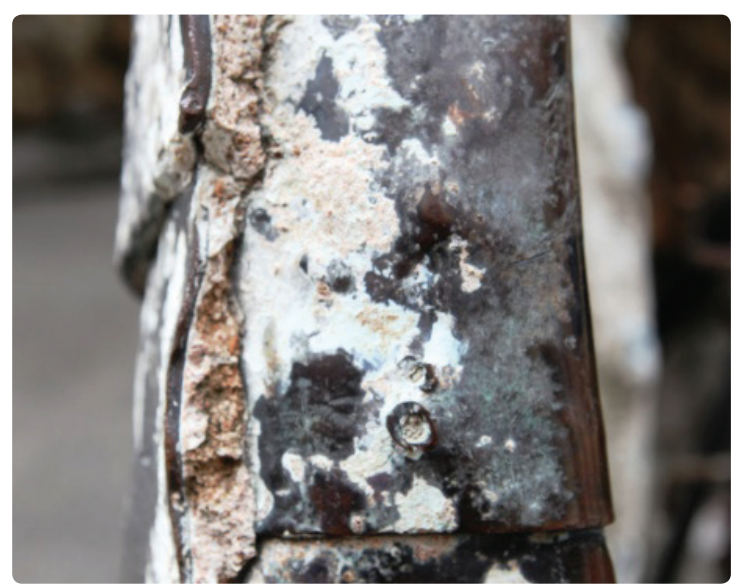

Resim 41. Tosya Tekke Hamamı külhan kazanı dış yüzünden ayrınt;; kasnak - yandan bakış (levhalar arasında kireç tabakası).

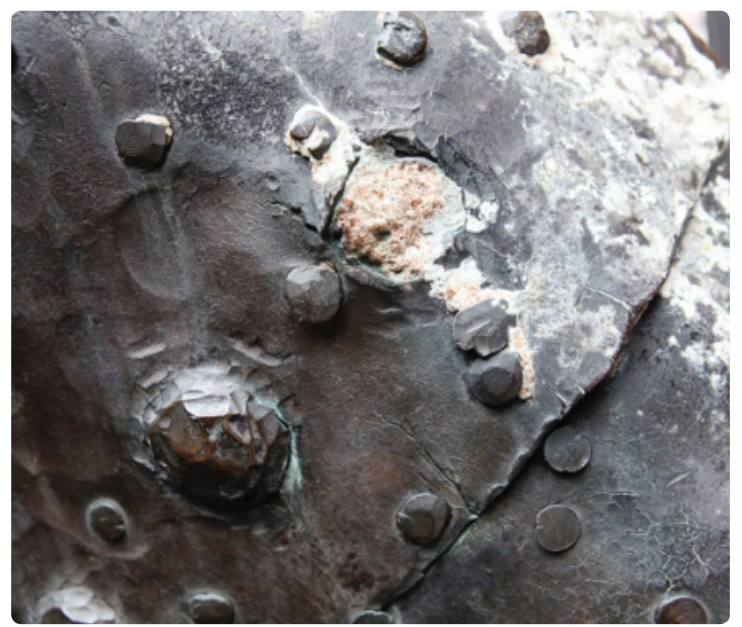

Resim 43. Tosya Tekke Hamamı külhan kazanı dış yüzünden çivi perçin ayrıntısı (üstte).

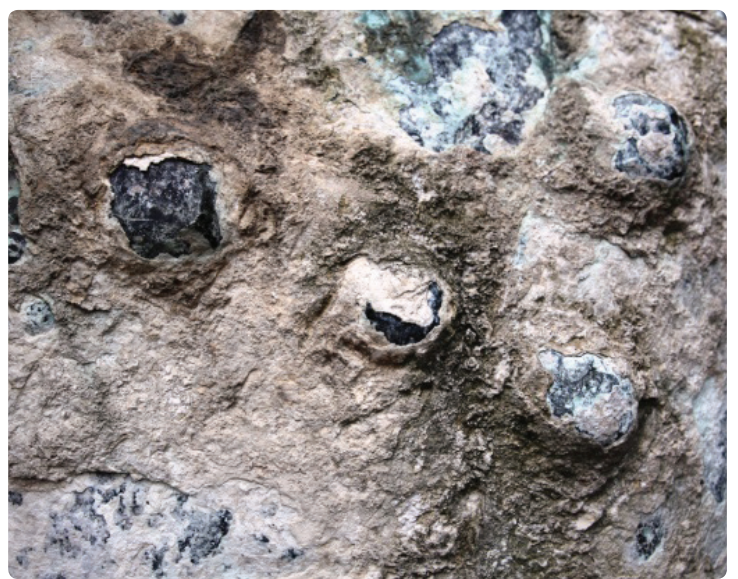

Resim 44. Tosya Tekke Hamamı külhan kazanı iç yüzünden çivi perçin ayrıntısı (altta); yüzey suyun bıraktı̆̆ kireçli tortuyla kaplı. 


\section{Karşılaştırma ve Değerlendirme ${ }^{30}$}

\subsection{Bir Kap Türü Olarak Kazan ve Kazanların} Sınıflandırılmasında Külhan Kazanlarının Konumu

"Çok miktarda yiyecek pişirmek veya su ısıtmak için kullanılan, silindirik formlu alt kısmı geniş, orta kısmı daralan ve yukarıya doğru genişleyen, bazı türleri kulplu ve kapaklı olan kapların geneline verilen ad" şeklinde tanımlanabilecek (Karpuz, 2002: 428; Dursun 2014: 804) kazanlar ${ }^{31}$ genellikle bulgur, pekmez, aşure kaynatmak, yemek pişirmek, et kavurmak ve çamaşır suyunu ısıtmada kullanılmaktadır (Karpuz, 2002: 428).

Kazanların Türk sanatında bilinen en eski örnekleri Asya Hunları'na kadar gitmektedir. Mutfak gibi günlük kullanım için olanları olduğu gibi döküm tekniğiyle imal edilen büyük tunç tören kazanlarının Minusinsk Havzası ve Altaylar'dan Macaristan ve Silezya kadar olan alanda yaygın olduğu, benzer bir geleneğin Timur devrinde olduğu gibi İslamî dönemde de görüldüğü anlaşılmaktadır (Çoruhlu, 2009: 1184-85).

Eski çağlardan beri biçimsel anlamda çok az değişikliğe uğradığı görülen kazanların Anadolu'da boyut, işlev ve tip olarak çeşitleri bulunmaktadır (Şekil 14, Resim 45-49). ${ }^{32}$

30 Bu başlık altında daha önce yayınlanmış bir külhan kazanı örneğine rastlayamadığımızdan incelediğimiz külhan kazanlarını kendi aralarında karşılaştırıp külhan kazanları ile ilgili bilinenler bağlamında bir değerlendirme ile madeni sanatlarda bilinen diğer kazan türleri ile benzerlik ve farklar bağlamda kısa tipolojik bir değerlendirme yapılmıştır.

31 "Kazan sözü kök olarak Türkçe olmakla birlikte Oğuzlardan bu yana dilimize girmiştir. Orta Asya Türkçesinde "Togan" kazan manasına gelmektedir." Bkz. Karpuz, 2002: 428. Birçok eski belgede kazan sözcüğü "kazgan" şeklinde ifade edilmektedir. Kuban, "kazgan" ifadesini "bakır kazan" şeklinde tanımlamaktadır (Kuban, 2007: 682).

32 Kahramanmaraş yöresinde kazanların büyüklüğüne göre farklı isimler aldığı; yörede tabanı $100 \mathrm{~cm}$.den büyük kazanlara "mesare kazanı" denildiği, üzüm şırası çıkarmada ve pekmez yapımında kullanıldığı, tabanı $55-80 \mathrm{~cm}$. arasında olan kazanlara "don kazanı" denildiği, çamaşır ve benzeri işlerde kullanıldığı, bunlardan daha küçük olanlarına "kelle
"Yöresel olarak formu ve fonksiyonu detaylarda farklılık gösteren kazanlar Anadolu'da farklı şekilde adlandırımaktadır... "Form olarak kuşaklı, kulaklı, küpeli gibi değişik adlarla anılan kazanların yanında fonksiyonuna göre şerbet kazanı, çamaşır kazanı, yemek kazanı şeklinde adlandırılanları da vardır... En yaygın olarak kullanılan kazanlar evlerde toplu yemeklerde kullanılan büyük, orta ve küçük kazanlardır"..."Kazanların bir başka grubunu içlerinde yemek pişirilmeyen, ocakta kullanılmayan, kulpsuz, yiyecek ve sıvı maddeleri taşımak, dağıtmak için kullanılan süslemeli prestij kapları oluşturur. Bunların dışında hamamda şu taşımak ve biriktirmek için kullanılan kazanlar da bulunmaktadır. Bunlar düz dipli, ağza doğru daralan ve kenarsız kazanlardır. Üzerlerinde zengin bezeme programları vardır. Kazanların kapaklı örnekleri de vardır." Bkz. (Karpuz, 2002: 428-429).

İşlev bakımdan bir başka kazan türü, birkaç yıl önce belgelenen ve geleneksel konut mimarimizin incelikli bir ayrıntısı olarak yorumlanabilecek "gusülhane kazanları"dır ${ }^{33}$ (Resim 49). Odalarda gömme dolaplar içerisine yerleştirilmiş gusülhanelerde bulunan bakır "gusülhane kazanları", yıkanma suyunu ısıtan donanımın bir elemanı olarak işlev bakımından külhan kazanlarına en yakın duran örneklerdir.

İncelediğimiz külhan kazanları, biçim olarak

kazanı” denildiği ve yemek işlerinde kullanıldığı, en küçüklerine ise "çorba kazanı" denildiği ifade edilmektedir (Kayaoğlu, 1991: 31).

33 “Gusülhane bakır kazanı: Odalarda gömme dolaplar içerisine yerleştirilmiş gusülhaneler, Anadolu konut mimarisinin olduğu gibi geleneksel Çorum evlerinin de en dikkat çekici düzenlemelerindendir. Ancak bazı erken 20. yüzyıl Çorum evlerinde görülen, içerisinde su ısıtmaya yarayan bir düzeneğin olduğu uygulamaya başka hiçbir yerde rastlanmaz. Bu örneklerde, tıpkı çarşı hamamlarında olduğu gibi duvar içerisine yerleştirilmiş küçük bakır bir kazan içerisindeki su, altına yerleştirilen haznede yakılan çalı çırpıyla ısıtılıp, kısa süreli banyo yapmaya uygun hale getirilir." (Tuluk ve Tuluk, 2016: 454). 
külhan kazanlarında olması beklenen tiptedir (Şekil 15). Kazanlar, ortası bombeli geri kalan kısmı düz bir dip ile yukarıya doğru düz devam eden, üstte dışa dönük düz bir ağız kenarıyla son bulan ve fazla derin olmayan gövdeden oluşan yalın bir biçime sahiptir. Yüksekliği 12$35 \mathrm{~cm}$., çapı 58-129 cm. arasında değişen tabandan yukarıya doğru bombeli kesim, her üç kazanda da bulunmaktadır. Mutfak kazanlarında ve tespit edebildiğimiz kadarıyla başka kap türlerinde bu tip bir bombe görülmez. Mutfak kazanlarının dipleri ya düz, ya da dışa dönük yuvarlaktır. Yemek pişirmek veya su kaynatmak vb. işlerde kullanılan kazanlardan farklı olarak külhan kazanlarında çok miktardaki yıkanma suyunun ısıtılması hedeflendiği için tabiatıyla böyle farklar görülmektedir. ${ }^{34}$ Yukarıda değindiğimiz üzere bazı Çorum konutlarında tespit edilen gusülhane kazanlarında bu tip bir bombenin olması beklenirse de ilgili araştırmada bu konuda bir tespit bulunmamaktadır (Tuluk ve Tuluk, 2016: 454-455). Bombe, suyun ısınması hızlandırmak için düşünülmüş olmalıdır. Bombe ile ateşin yanması için daha uygun bir hacim elde edilmiş, ayrıca alevlerle kazan yüzeyinin teması arttırılmış ve böylece daha etkin bir yanma-ısınma sağlanmıştır.

Kazanları "dergâh, saray gibi yerlerde kullanılan büyük tören kazanları" (Resim 45) ile "evlerde kullanılan küçük boyutlu kazanlar" (Resim 46-

34 Hamamlarda külhan kazanlarından farklı olarak su taşımak ve biriktirmek için kullanılan başka kazanlar kullanıldığı belirtilmektedir. Bunların tip olarak külhan kazanlarına benzemediği, orta ve küçük boyutlu yemek pişirmek ve su kaynatmak için kullanılan kazanlara benzediği görülmektedir. "Hamamda su taşımak ve biriktirmek için kullanılan kazanlar da bulunmaktadır. Bunlar düz dipli, ağza doğru daralan ve kenarsız kazanlardır." (Karpuz, 2002: 429). "Hamam Leğeni: Çapı 35-40 cm. arasında değişen kulpsuz bir kazan türü olup "leğen" adıyla anılmaktadır. Kadınlar tarafindan hamama götürülerek içerisine su doldurulup kullanılır. Yemek kazanlarından farklı olarak özel bir biçimi olan hamam leğeninin ağız kısmı tırnaksızdır." (http://yumurtaliekmek. com/bakircilik-nedir-bakir-urunler-nelerdir/).
47) olarak iki gruba ayırarak incelemek gerektiği şeklinde bir görüş bulunmaktadır (Karpuz, 2002: 428). Boyut ve kullanım alanı dikkate alınarak yapıldığı anlaşılan bu tasnife göre külhan kazanları boyut olarak birinci gruba uysa da "dergâh, saray gibi yerlerde kullanılan" tanımlamasına uymamaktadır. İkinci gruba ise hem boyut hem kullanıldığı yer bakımından uymaz. Külhan kazanlarını, hamamın yapı müştemilatının sabitlenmiş bir öğesi olduğu gerçeğinden hareketle yeni bir grup olarak "külhan kazanları” başlığıyla değerlendirilmek mümkündür. İşlev bakımından külhan kazanlarına son derece yakın duran gusülhane kazanlar ${ }^{35}$ bu tasnifte külhan kazanları ile birlikte aynı başlıkta -"külhan ve gusülhane kazanları” şeklinde adlandırılarak- ele alınabilir.

Başka bir yaklaşımla; yukarıdaki tasnifi "büyük boyutlu törensel vb. kazanlar" ve "mutfaklarda kullanılan gündelik kazanlar" şeklinde yenilersek, külhan kazanlarını, bu bakışla birinci gruba dâhil edebiliriz. Ancak yukarıda değindiğimiz birinci alternatifi -külhan kazanlarını gusülhane kazanları ile birlikte müstakil bir grup olarak "külhan ve gusülhane kazanları" başlığıyla sınıflandırmayı- daha uygun gördüğümüzü belirtmek isteriz.

35 Gusülhane kazanlarını yukarıda değindiğimiz araştırmadaki kısa tanıtım ve fotoğraflardan tanıma imkânı bulabildik. Araştırmada -konusu gereği- gusülhane kazanlarının imal tekniği, biçim, boyut vb. özellikleri hakkında ayrıntıya yer verilmediğinden konu ile ilgili sınırlı bir karşılaştırma imkânı bulabildiğimizi belirtmek isteriz. Ayrıntılı bir şekilde incelenmesi gereken gusülhane kazanlarının belirtilen bölge dışında da var olup olmadığı ayrıca araştırılmalıdır. 


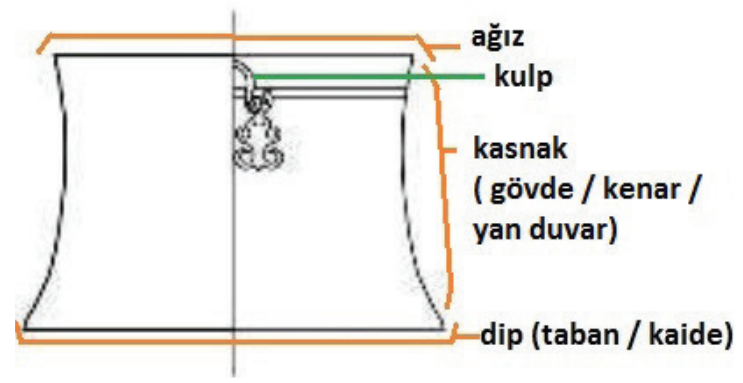

Şekil 14. Tipik bir mutfak (yemek) kazanı bölümleri, kesit ve görünüşü (Dursun, 2014: 814 -yazılar ilave edilmiştir).

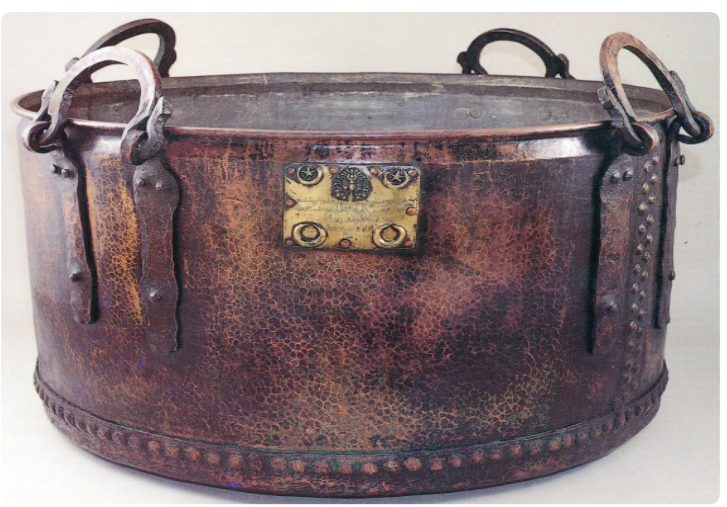

Resim 45. Büyük boyutlu kazan örneği. Istanbul imalat, 20. yüzyıl dövme bakır dergâh kazanı, Kulplu, yükseklik 83 cm., çap 135 cm., ağırlık 240 kg. çivi perçinli birleştirme kullanılmış (Belli ve Kayaoğlu, 1993a: 94). Üzerindeki pirinçlevhaya yazılı kitabesinde Hicri 1326 (M. 1908-09) tarihi yazılıdır.

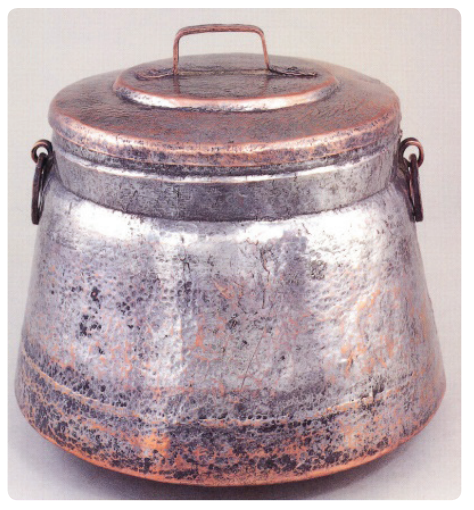

Resim 47. Küçük boy kazan örneği. Erzurum imalat, 19. yüzyılın 2. yarısı dövme bakır mutfak kazanı. Kapaklı kulplu, yükseklik $33 \mathrm{~cm}$., çap $30 \mathrm{~cm}$. (Belli Kayaoğlu 1993a: 237).

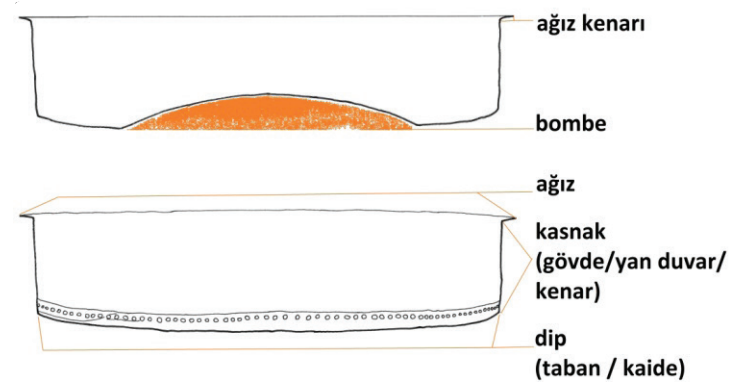

Şekil 15. Külhan Kazanın bölümleri (Turuncu boyalı kesim, kazanın tabanındaki bombeli yüzeyin altındaki boşluğu göstermektedir).

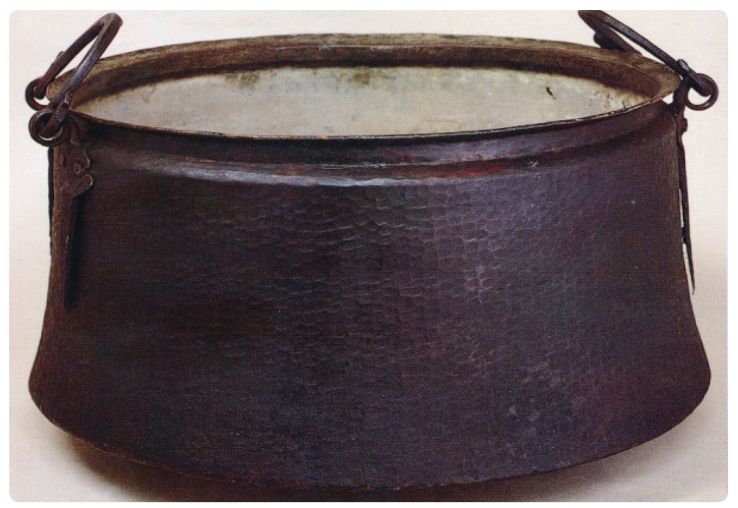

Resim 46. Orta boy kazan örneği. \}Çanakkale imalat, 19. yüzyıl dövme bakır Çanakkale ve Rumeli'ye özgü mutfak (yemek) kazanı. Kulplu, yükseklik $30 \mathrm{~cm}$., çap $43 \mathrm{~cm}$. (Belli ve Kayaoğlu, 1993a: 124).

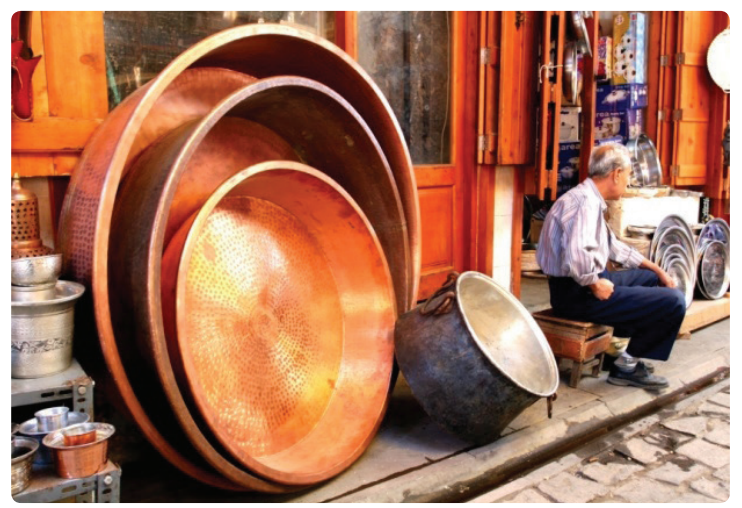

Resim 48. Külhan Kazanlarına form ve boyut açısından benzerlik gösteren masere (mahzere) kazanlarına Gaziantep'ten yakın zamanlarda geleneksel yöntemlerle imal edilen örnekler. (http://www.gto.org.tr/Bakircilar-Carsisi-fotogaleri-3.html)

36 Kazanın bölümlerinin isimlendirilmesinde, ilgili yayınlarda kullanılan terimler dikkate alınmıştır. Illk sırada yazılanı şahsen daha fazla tercih etmekteyiz. Yayınlardaki haliyle bir fikir birliği görünmediğinden okuyucunun diğer isimlendirmeleri de görmek isteyebileceğini düşünerek diğer isimlendirmelere parantez içerisinde yer verilmiştir. 


\subsection{Incelenen Külhan Kazanların Tarihlendirilmesi}

Çoğu madenî eserde olduğu gibi her üç kazanda da herhangi bir usta ismine rastlanmamaktadır. Kazanların üzerlerinde imal tarihi konusuna ışı tutacak bir tarih veya yazı unsuru bulunmamaktadır. Konuyla ilgili bir belge de tespit edemedik. Ait oldukları yapıların inşa tarihinde yapılmış olabilecekleri tabii bir ihtimal olarak kabul edilmelidir. Ancak Dede Sultan Hamamı kazanında olduğu gibi sonradan tamir görmüş veya yenilenmiş olabilecekleri de unutulmamalıdır. Bu durumda kazanlar kronolojik olarak 1273-1274 dolayında (Çobanoğulları), 1637 'den birkaç yıl önce ve 1766-1767 (Osmanlı) tarihlerinden kalmadır (Tablo. 1). Belirtilen tarihlerden ilki oldukça eskidir. Önge'nin daha önce değindiğimiz üzere "XII-XIII. yüzyıllara ait orijinal bakır kazanlardan hiçbiri günümüze kadar gelememiştir." şeklindeki ifadeleri sanırız Kastamonu'daki Vakıf Hamamı külhan kazanını görme firsatı bulsaydı ${ }^{37}$ değişebilirdi.

\section{3. İncelenen Kazanların Teknik Özellikleri}

\subsubsection{Kazanları Oluşturan Levhaların İmali}

İncelediğimiz kazanları oluşturan levhaların tamamı bakırcılıkta en eski ve yaygın olan "dövme" tekniğinde imal edilmişlerdir. Bakırcılıkta görülen en eski yapım tekniği olan dövmeyi bakırın sert bir zemin üzerinde, sert bir araçla darbelenerek şekillendirilmesi şeklinde tanımlayabiliriz (Naldan, 2014: 780). ${ }^{38}$ En temel yapım

37 Ülkemizde hamam ve su yapılarıyla ilgili en yetkin isimlerden olan merhum Yılmaz Önge hocamızın bu hamam kazanından haberdar olamadığını sanıyoruz. Zira "Anadolu'da XII-XIII. Yüzyıl Türk Hamamları" adlı kitabında, hem Vakıf Hamamı'nın ayrıntılı bir şekilde tanıtıldığı bölümde hem de hamamların külhan donanımı ve külhan kazanları hakkındaki tespit ve değerlendirmelerinin bulunduğu bölümde Önge, bu kazandan söz etmemektedir.

38 “ince bir levhanın kütük ya da örs üstünde çekiçle dövülerek biçimlendirilmesidir. Sığ ve ağzı geniş olan tas, tabak, sini, sahan gibi kaplar genellikle "çökertme" yoluyla içten çekiçlenerek; yüksek ve derin olan ibrik, maşrapa, vazo gibi kaplarsa "yükseltme" yoluyla dıştan çekiçlenerek yapılır. Bu teknikle yapılan parçalarda emzik ve kulp gibi bölümler ayrıca üretilip gövdeye lehimle birleştirilir. Ancak çok becerikli ustalar, tek parça levhadan kulplu ve emzikli kaplar yapabilir." (Erginsoy, 1997: 1140). "Dövme tekniği, bakır külçeyi tekniği olan dövmenin ilk olarak Yakın Doğu'da keşfedildiği, Anadolu'da MÖ. yedinci binde bilindiği anlaşılmaktadır (Erginsoy, 1978: 18).

\subsubsection{Levha Birleştirme Teknikleri}

Her üç kazan da bakır cevherinden dövülerek elde edilen birkaç levhanın, kazanın boyutlarına ve şekline göre, "perçin" veya "bakır kaynağı" (kat lehim) tekniği ile birleştirilmesi suretiyle imal edilmişlerdir (Tablo. 3). Kazanların boyutları büyük olunca birden fazla levha gerekmiş ve bu levhalar geleneksel bakırcılıkta bilinen usuller kullanılarak birleştirilmiştir. Bu usuller "perçin ve kat lehim olmak" üzere iki çeşittir (Erginsoy, 1978: 29-31). ${ }^{39}$

Vakıf Hamamı kazanı, ikisi taban ikisi kasnakta olmak üzere dört büyük levhadan oluşmaktadır. Levhalar birbirleri üzerine bindirilerek perçinlerle birleştirilmiştir. Dede Sultan Hamamı kazanı, dördü taban, dördü kasnakta olmak üzere, sekiz ayrı levhadan imal edilmiştir. Levhalar birbirlerine bakır kaynağıyla tutturulmuştur. Tekke Hamamı kazanında ortadaki levhayı çepeçevre saran dokuz levha kazanın dip kısmını, bunların devamındaki iki ayrı levha kasnağı tamamlar. Toplamda 12 levha, birbirlerine perçinlerle birleştirilmiştir. Amasya Mustafa Bey Hamamı (15. yüzyıl) (Önge, 1995: 45, 51) külhan kazanının da benzer şekilde; ortadaki levhayı çepeçevre saran levhaların birbirlerine perçinlenmesi suretiyle yapıldığı anlaşılmakta$\operatorname{dir}(\operatorname{Resim} 50)$.

çekiçlemek suretiyle şekillendiren en eski tekniktir. "Ham bakır" kalhanede eritildikten sonra tahta (sonra da pik demirden yapılmış) kalıplara dökülür. Bunlardan çıkartılan külçeler, uzun ağır çekiçlerle dövülerek levha haline getirilir. Bu işlem sayıları 5-10 arasında değişen "kol" adı verilen, bir ekip tarafindan gerçekleştirilir." (Leventoğlu, 2006: 33). Dövme tekniği hakkında ayrıntılı bilgi için bkz. Erginsoy (1978: 18-25); Kayaoğlu (1984: 222); Erginsoy (1997: 1140).

39 "Eski ve Orta Çağlara ait madenî eserlerden yalnızca demirden olanlara sıcak-basınç ile kaynak uygulanabilmiş; diğer madenlerden yapılan eserler perçin veya lehim kullanılarak birleştirilmiştir." (Erginsoy, 1978: 31). Diğer birçok araştrrmacının bu tekniğe "kaynak", "bakır kaynağı" gibi isimler verdiği görülmektedir ki aşağıda ayrıntılı bir şekilde değinilmektedir. 


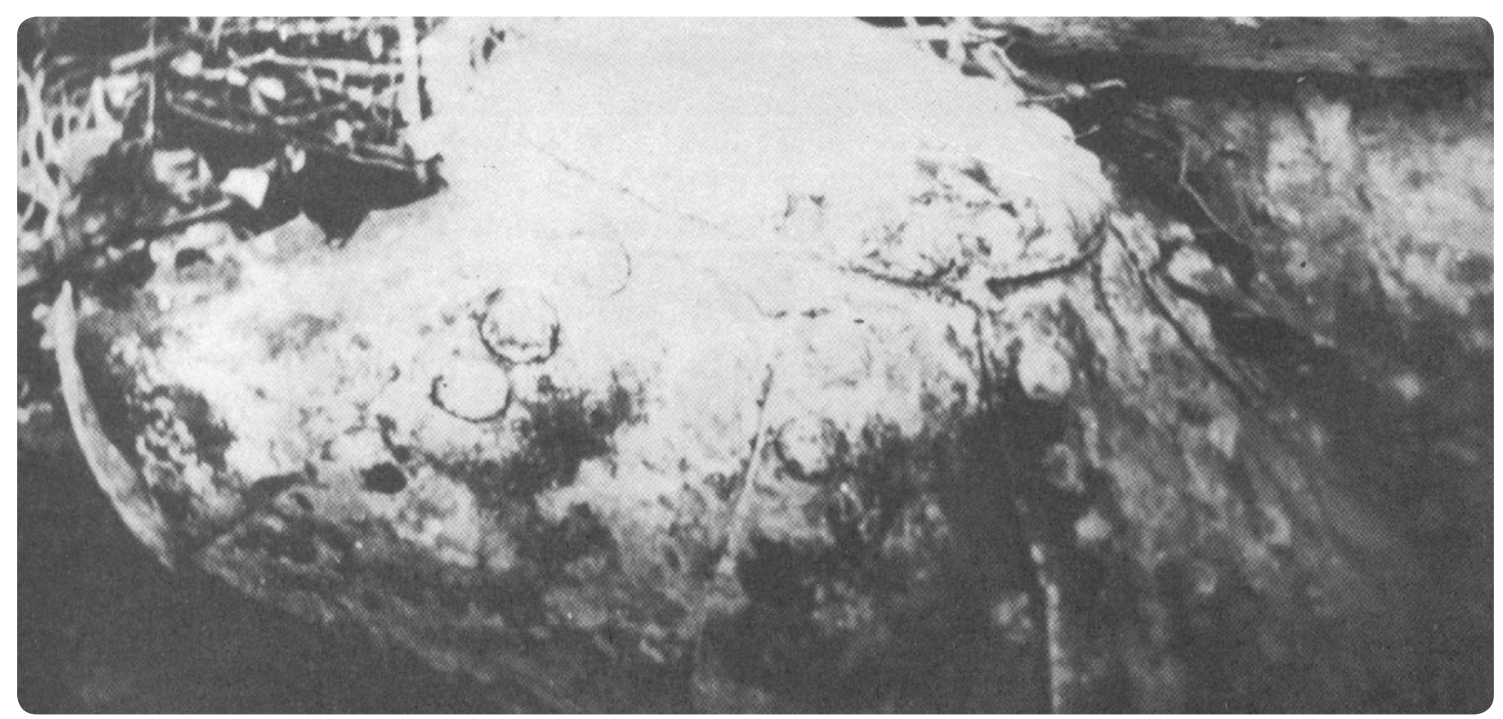

Resim 49. Amasya Mustafa Bey Hamamı (15. yüzyıl) külhan kazanı (Önge, 1995: 45, 51).

\subsubsection{Perçin}

Incelediğimiz kazanlardan Vakıf Hamamı ve Tekke Hamamı kazanlarında kullanılan birleştirme yöntemlerinden perçin, bakırcılıkta yaygın olarak kullanılan eski bir usuldür. Sivri uçlu bir aletle bakır levhalara delikler açılır sonra delikler üst üste gelecek şekilde levhalar birleştirilip bakır çivi bu deliklerden geçirilir. Daha sonra çivi ve bakır levha çekiçle dövülerek sıkıştırılır (Kayabaşı, 1997:230) (Şekil 16-17). Perçinler oldukça sağlam bir birleştirme yöntemidir. Tahrip edilmeden sökülmeleri mümkün değildir. ${ }^{40}$

\subsubsection{Bakır Kaynağı (Katı Lehim)}

Bu teknik sadece Dede Sultan Hamamı kazanında kullanılmıştır. Geleneksel bakır işçiliğinde kazan gibi büyük boyutlu eserlerin genelde "kaide ve yan duvar" (kasnak) olmak üzere iki ayrı parçadan yapıldığı, bunların birleşecek kenarlarının diş şeklinde kesilip birbirlerinin içine geçirilip kenetlendiği ve dişlerin üzerine lehim sürülüp, lehimin ısıtılarak dişlerin arasına akıtılmasından sonra ek yerinin çekiçle dövüldüğü ve böylece çok sağlam bir birleşme sağlandığı bilinmektedir (Erginsoy, 1978: 30) (Resim

40 Günümüzde de su tankları, mutfak gereçleri, su oluklarında perçinleme teknolojik yeni usullerle kullanılmaktadır. Bkz. http://w3.balikesir.edu.tr/ ay/lectures/mmg/lecture5.pdf
50-54). Belirtilen yöntem Erginsoy'a göre "kat lehim" (sert lehim) denilen; altın gümüş bakır tunç ve pirinç gibi maddelerin birleştirilmesinde kullanılan lehimdir. ${ }^{41}$ Kimi araştırmacılar bunu "kaynak"42, "bakır kaynağı"43, "diş açılarak

41 "Yumuşak lehim" denilen yalnızca kurşun borular ve kalay levhalarının birleştirmelerinde kullanılan, tavlama ve çekiçleme yapılamayan ve maden sanatında kullanılmayan (Erginsoy 1978: 29) diğer bir lehim çeşidi vardır ki bu konumuz dışındadır. Kimi araştırmacıların "kaynak" şeklinde nitelendirdiği lehim türü, kat lehimdir.

42 "Kaynak yapımında kullanılan ilk madde bakır eğintisi ve çinkodur. Bu iki madde $1 / 2$ oranında karıştrıldıktan sonra içerisine ayrıca 1/3 oranında tenekâr (boraks), 1/4 oranında kaya tuzu katılır; hepsi toz haline getirilir. Kaynak yeri ıslatılır, hazırlanan toz, oraya döküldükten sonra iş, ocakta kızdırııır. Böylece kaynak yapılmış olur." (Kazmaz, 1997: 110). Burada sözü edilen geleneksel kaynak yöntemidir.

"Kaynaklı birleştirme ise bakır işlerinde çok uygulanan bir yöntemdir. Parçalar, birbirine düz olarak (güğümde boyun-göğüs birleştirmesi) ağız ağıza kaynak yapılabildiği gibi diş açarak da (gügü̈mle taban, göğüs birleştirmesi) kaynatlabilir. Ayrıca kaynak, dövülerek parçaların birleştirilmesinde ve döverken çatlayan yerlerin onarılmasında da uygulanan bir işlemdir" (Kayabaşı 1997:230).

43 "Bazı büyük kablarda (kazan, tist vs.) dip ve kasnak iki parça halinde yapıldığından, bu parçalar kaynak yapılarak birleştirilir. iki türlü kaynak kullanıı;1-Tutya kaynağı (çinko) 2-Bakır kaynağı. İster tutya, ister bakır kaynağı olsun bunlar eritilir, süpürge veya buna benzer bir şeyin üzerinden suya dökülür, suyun içinde domur, domur olur. Bir ölçüsüne, üç ölçü boraks (tenkâr) katllır ve havanda dövülerek toz haline getirilir. Bu toz iki parçanın birbirine birleştirilmesinde kullanılır. Dip ve kasnağı birbirine geçirirken, dip kısmına diş makası ile dişler açılarak kasnağı geçirilir, dişler kapatılarak üzerine toz halindeki kaynak serpilir. Kab ateşin üzerine konur, ateşte kaynak eriyerek parçalar birbirine yapışır. Kaynak yapılan kısım örs üzerinde dövülerek pürüzleri giderilir." (Memişoğlu, 1973: 37). 
birleştirme" ${ }^{44}$ ve "dişli perçin" (Kuşoğlu 2006: 185) şeklinde nitelendirmektedir. ${ }^{45}$ Görüldüğü üzere araştırmacılar benzer tarifler vererek aynı tekniğe işaret etmekte fakat tekniğin adını farklı isimlerle ifade etmektedir. Yukarıdaki tanımlama ve görüşlere bakılarak tekniği "bakır kaynağı (kat lehim)" şeklinde isimlendirmeyi uygun bulmaktayız. Mesleği bırakan ve yaşlı bir-iki ustanın dışında bakırcı ustasının bulunmadığı şehirde, belirtilen ustalarla görüşme imkânı bulamadığımızdan ${ }^{46}$ belirtilen tekniği Kastamonulu ustaların nasıl isimlendirdiklerini, şehirde üretime devam eden tek kalay ustası olduğunu ifade eden Raşit Yazıcı'ya sorduk. Yazıcı, sorumuzu tereddütsüz bir şekilde "kaynak" şeklinde cevaplamıştır.

Dede Sultan Hamamı kazanın sadece kasnağında, dört levhanın birleştiği dört yerde diş izleri seçilebilmektedir. Taban levhasında ise diş izleri görülememektedir. Belirtilen kesimlerde kaynak tozu, kasnaktakilere nispetle bol kullanıldığından diş izleri kapanmış olmalıdır. Kazanın büyük oluşu, diş derinliklerinin artmasına sebep olmuştur. Daha fazla yüzeye uygulanan bakır kaynağı mukavemeti arttırmıştır. Diş derinlikleri takriben $1.5 \mathrm{~cm}$., diş genişliği (eni) ise $2.5-5$. cm. aralığındadır. Küçük boyutlu kazanlarda diş derinlikleri de diş genişliği de daha küçük ölçülerdedir (Resim 26-31, 51-55).

44 "Bu yöntemde birleştirilecek iki parçadan sadece bir parçaya çentik açılır. Bu çentikler düz tarafa geçirilir, çekiçlenerek birbirine geçmesi sağlanır. Bu işlemden sonra çentikler üzerine kaynak tozu serpilir ve böylece arada kalan boş yerlere toz dolar. Sonra yüksek ısıda ısıtılarak, birleştirme işlemi tamamlanmış olur." (Dursun, 2014: 803).

45 Erginsoy'un bu konudaki görüşüne yukarıda yer vermiştik.

46 Kendisiyle yaptığımız kişisel görüşmede Raşit Yazıcı, şehirde eski bakırcılardan yaşayan bir ustanın bulunduğunu onun da söyleşi yapamayacak kadar yaşlı ve hasta olduğunu ifade etmiştir.

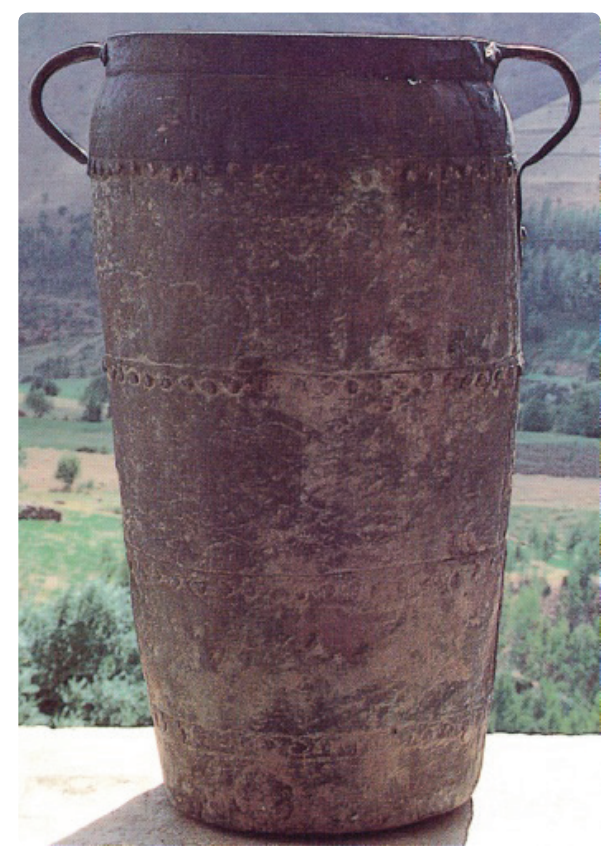

Resim 50. Siirt imalâtı bakır perçinli küp, yükseklik 90 cm., çap $48 \mathrm{~cm}$. (Belli ve Kayaoğlu, 1993a: 282).
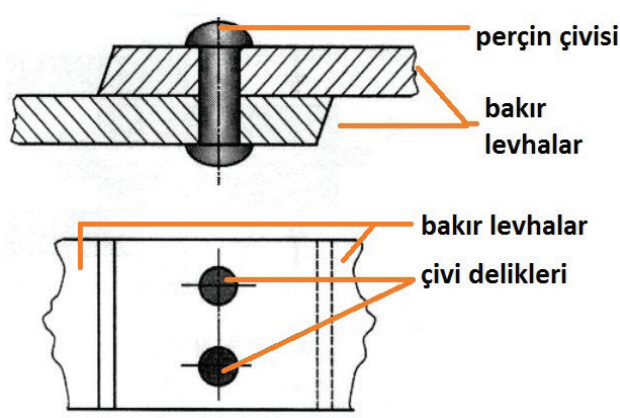

Şekil 16. Geleneksel çivi perçinle aynı tekniğe sahip günümüz "Bindirmeli perçinleme (tek kesimli tek sıralı)" şematik çizimi (yazılar ilave edilmiştir). (http:// w3.balikesir.edu.tr/ ay/lectures/mmg/lecture5.pdf)

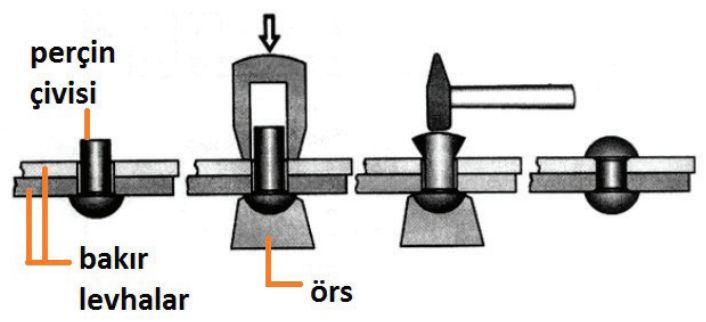

Şekil 17. Geleneksel çivi perçinle aynı tekniğe sahip günümüz "Elde perçinleme" aşamaları şematik çizimi (yazılar ilave edilmiştir). (http://w3.balikesir.edu. tr/ ay/lectures/mmg/lecture5.pdf) 


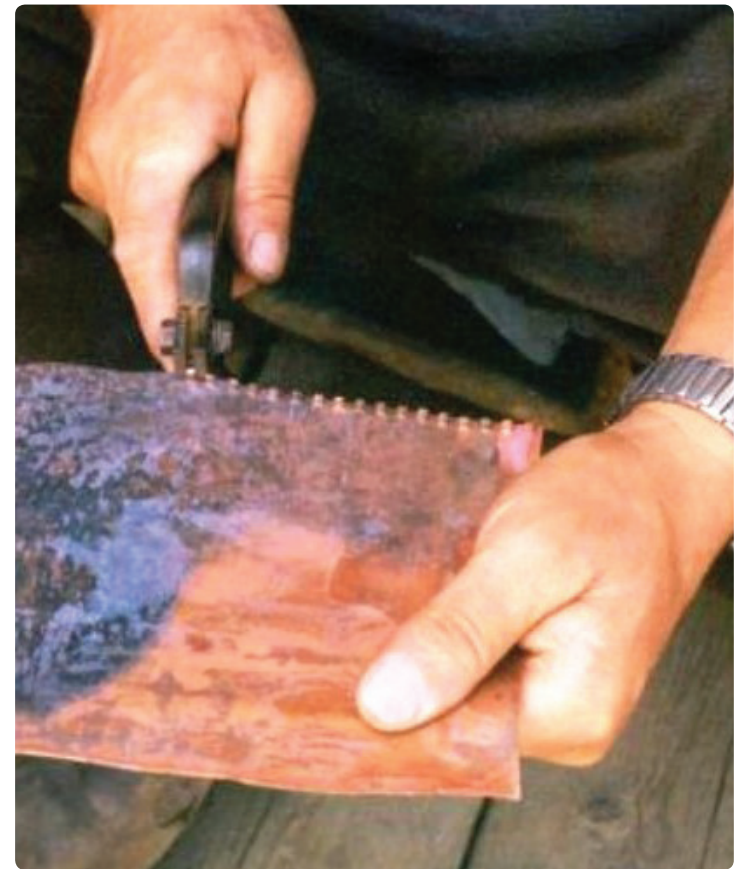

Resim 51. "Bakır kaynağı" ("kaynak", "kat lehim", "diş açarak birleştirme" ve "dişli perçin") birleştirme safhalarının ilki; "çentik" (diş) açma (Dursun, 2014: 817).

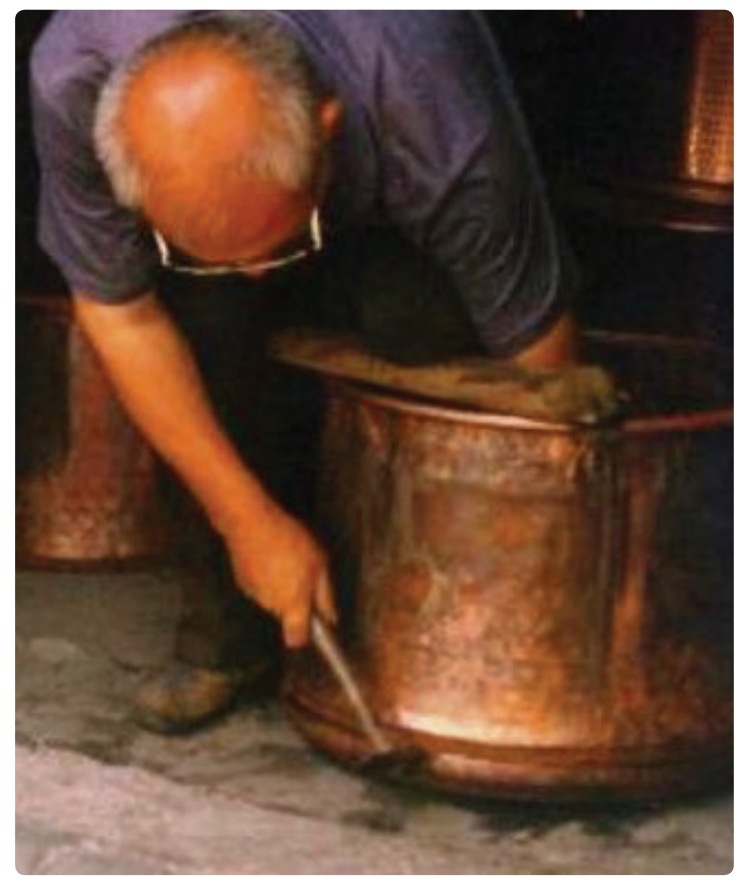

Resim 53. "Bakır kaynağı" ("kaynak", "katı lehim", "diş açarak birleştirme" ve "dişli perçin") birleştirme safhalarının üçüncüsü; "tabanın geçirilmesi" (Dursun 2014: 818).

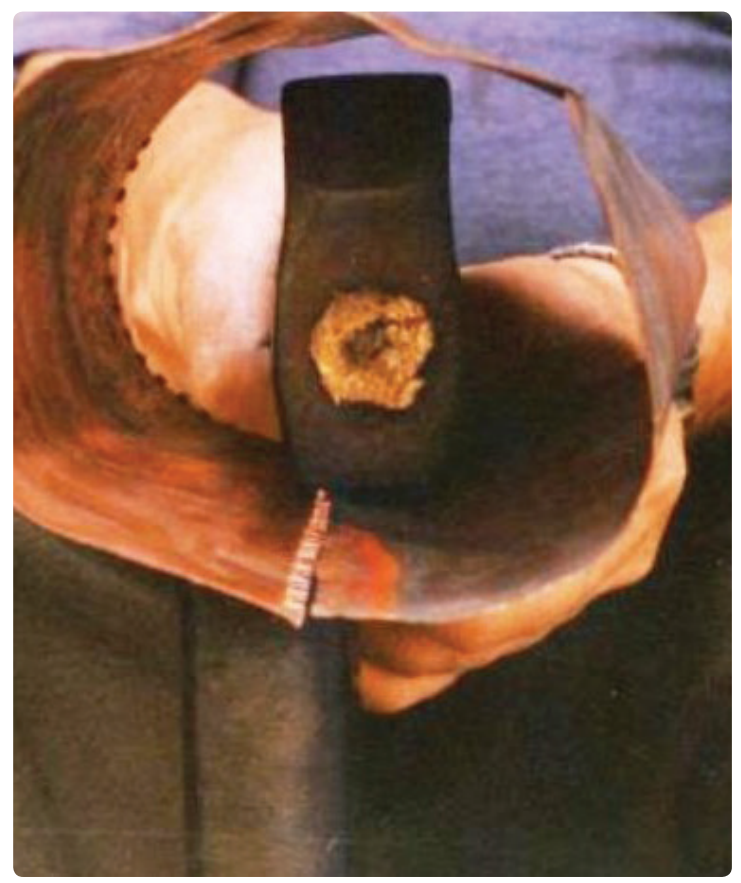

Resim 52. "Bakır kaynağı" ("kaynak", "kat lehim", "diş açarak birleştirme" ve "dişli perçin") birleştirme safhalarının ikincisi; "çekiçle dövme" (Dursun 2014: 817).

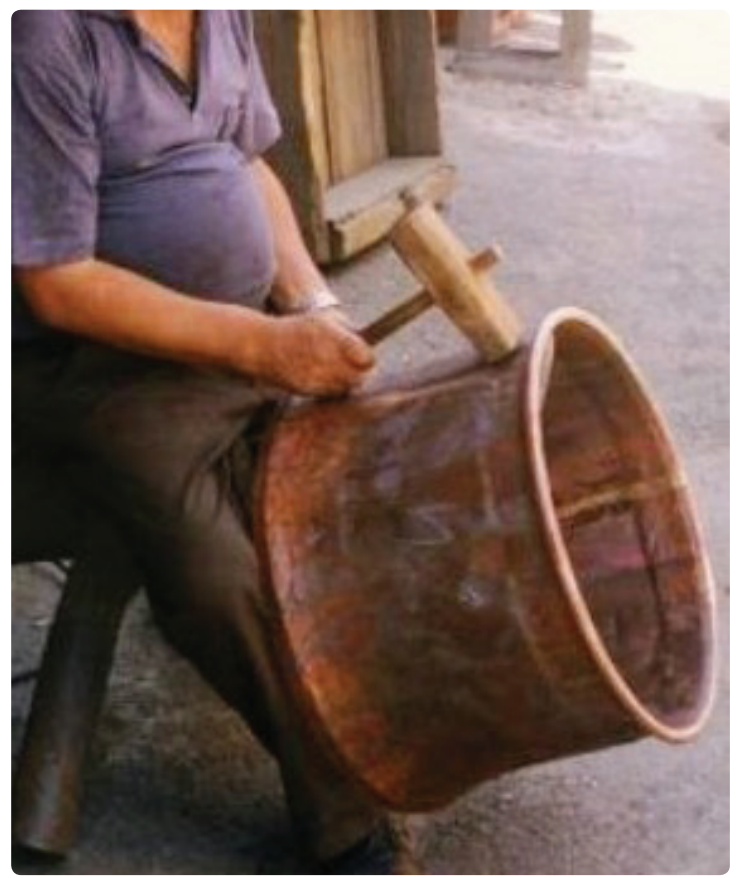

Resim 54. "Bakır kaynağı" ("kaynak", "kat lehim", "diş açarak birleştirme" ve "dişli perçin") birleştirme safhalarının dördüncüsü; "tokmakla düzeltme" (Dursun 2014: 818). 
Dövme bakırcılıkta; yüzeyi iyice düzgünleştirmek, parçaya son şeklini vermek, göze hoş gelmeyen çekiç darbelerini gidermek ve güzel görünmesi için, çekiç darbeleriyle dış yüzeye eşit aralıklarla sıralı olarak döndürülerek darbeler vurularak yapılan "perdahlama" (Kayabaşı, 1997: 230; Kuşoğlu, 2006: 186) incelediğimiz külhan kazanlarında görülmez. Neden olarak da kazanın teknik özellikleri ve türü ile ilgili olduğunu düşünebiliriz. Zira kazanı oluşturan levhalar perdahlama için oldukça kalındır. Ayrıca insanların gözünden uzak, hamamın külhanında sabit duracak kazanlar için böylesi bir işleme gerek görülmemiş olmalıdır.

\section{4. İncelenen Külhan Kazanların Biçimsel Özellikleri}

Kazanların biçimi ve birleştirmelerinde kaliteli bir işçilik sergilenmiştir. Yukarıda da değindiğimiz gibi kazanlar, külhan kazanlarına has biçimleriyle ve büyük boyutlarıyla dikkat çekmektedir (Tablo. 2). Daire şeklindeki kazanların çapları 165-204.5 cm. arasında değişmektedir. Kazanların en büyüğü Vakıf Hamamı kazanıdır. Diğer ikisi birbirlerine çok yakın ölçüde olmakla birlikte Tekke Hamamı kazanı daha küçüktür. Büyük kazanlar sınıfinda Türk kaplarında "aşure, şerbet, helva gibi yiyecek ve içeceklerin pişirildiği ve dağıtıldığı büyük kazanlar" bilinmektedir (Karpuz, 2002: 429). Ancak onların da tipleri külhan kazanlarından farklı olarak gündelik olarak yemek pişirilen veya su kaynatılan küçük ve orta boylu kazanlara benzemektedir. ${ }^{47}$ Bu tiplerde; küçük boyutlu kazanların çapları $30-35 \mathrm{~cm}$., orta boyutlu kazanların çapı 35 - $45 \mathrm{~cm}$., büyük boyutlu kazanların çapları $50-60 \mathrm{~cm}$. arasında değişmektedir (Naldan,

47 "Araştırdığımız kentlerdeki kazanların bir grubunu büyük boyutlu dergâh kazanları oluşturmaktadır. Bu kazanlar belirli günlerde aşure, şerbet, helva gibi yiyecek ve içeceklerin pişirildiği ve dağıtıldığı büyük kazanlardır. Bunlar iki veya dört kulpludurlar ve mutfaklarda yer alan özel kaidelere oturtulurlar. Form olarak silindir gövdeli, büyük kulplu ve ağız kenarı dışarı taşkındır." (Karpuz, 2002: 429).
2014: 785). Tabii olarak külhan kazanları, boyut itibariyle epey daha büyüktür.

Kazanların derinliğine bakıldığında ölçüler 32$37 \mathrm{~cm}$. arasında değişmektedir (Tablo. 1). Bu da külhan kazanlarında olması beklenen ölçülerdir. Zira su deposunun altını kapatan kazan gövdesinin fazla yükselmesine gerek yoktur.

Levha kalınlıkları 0.3-0.7 cm. arasında değişmektedir (Tablo. 3). El işçiliğiyle dövüldüklerinden aynı kazanda levha kalınlıkları küçük farklılık gösterebilmektedir. Vakıf Hamamı kazanında levha kalınlığı 0.4-0.5 cm., Dede Sultan Hamamı kazanında 0.3-0.4 cm., Tekke Hamamı kazanında ise $0.3-0.7 \mathrm{~cm}$. arasındadır (Tablo. 3). Görüldüğü üzere en ince levha Dede Sultan Hamamı kazanında, en kalın levha ise Tekke Hamamı kazanında bulunmaktadır. Vakıf Hamamı kazanı diğerlerinden epey daha büyük olmasına rağmen levha kalınlığı Tekke Hamamı kazanından ortalama $0.1 \mathrm{~cm}$. daha düşüktür.

Çok uzun yıllar hizmet vermek için tasarlanan hamamlara ait külhan kazanlarının uzun ömürlü ve sağlam olmaları gerekmektedir. Bu sebeple kaliteli işçilikli ve kalın bakır levhalar tercih edilmiştir. Yapımı en fazla güç gerektiren kabın kazan olduğu düşünülürse bakırcılık zanaatnın en fazla güç gerektiren kolunun kazancılık olduğu söylenebilir. Muhtemelen kazancılığın da en zorlu alanı, külhan kazanı imalatı olmalıdır. Yakın zamanlara kadar bakırcılığın devam ettiği şehirdeki kazan ustalarının, incelediğimiz külhan kazanlarını büyük bir takdirle karşılayıp günümüzde bu işçiliği yapabilecek ustanın bulunamayacağını beyan ettikleri rivayetleri, halk arasında dolaşmaktadır. Bakır eşyanın ağır, sağlam ve dayanıklı olduğu için tercih edildiği, bu sebeple eskilere gidildikçe daha kalın ve ağır işçilikle karşılaşıldığı şeklindeki görüşü (Kazmaz, 1997: 114), incelediğimiz kazanlar teyit etmektedir. Biçim olarak külhan kazanlarının en yakın benzeri, Tüm Anadolu'da görülen Güneydoğu 
yöresinde "mesare kazanı" denilen" ${ }^{48}$, bakırdan yapılmış üzüm şırası çıkarmada ve pekmez yapımında kullanılan fazla yüksek olmayan, kulpsuz, geniş ve düz dipli kazanlardır (Resim 48). Ancak bunlarda da külhan kazanlarındaki bombe görülmez. ${ }^{49}$ Biçimsel anlamda külhan kazanları bombeli tabana sahip, silindirik gövdeli, kulpsuz ve kapaksız kazanlardır.

\section{5. İncelenen Kazanların Süsleme Özellikleri}

Kazanlarda herhangi bir süs unsuru bulunmaz. Perçinlerde faklı kesimlerde şaşırtma sıralı ve karşılıklı sıralı (aynı hizada) düzen kullanıldığı dikkat çekmektedir. Vakıf Hamamı kazanı ve Tekke Hamamı kazanında olduğu gibi ritmik tekrarlı perçinlerde sınırlı da olsa dekoratif ve estetik bir düzen doğurmuştur.

\section{Sonuç}

Madeni eserler, tarih boyunca gerek değerlerinden ötürü gerek kolayca taşınabildiklerinden dolayı büyük ölçüde, günümüze ulaşamadan tarihe karışmış eserlerdir. Özellikle Anadolu tarihinde görülen istila, savaş, afet gibi olaylar birçok eserin eritilip sikkeye çevrilmesi veya başka ülkelere çıkarılması suretiyle ortadan kalkmıştır. ${ }^{50}$ Kastamonu'daki üç külhan kazanının günümüze kadar ayakta kalmaları bu bakımdan önemlidir.

Günümüze gelen çoğu madeni eserin kitabesiz oluşu madeni eserlerin kesin bir şekilde tarihlendirilmesini güçleştirmektedir. İncelediğimiz örneklerin aidiyetleri ve imal tarihleri konusu da benzer bir durumdadır. Malzeme ve teknik özellikleri ve yapı tarihçelerinden hareketle kanaatimizce külhan kazanların en eskisi Ço-

48 Kahramanmaraş yöresinde aynı işlerde kullanılan "mesare teşti" adı verilen aynı biçim özelliklerine sahip bir leğen türü bulunduğu, yörede büyük leğenlere teşt adı verildiği anlaşılmaktadır (Kayaoğlu, 1991: 31).

49 Daha fazla bilgi için bkz. Belli ve Kayaoğlu, 1993a: 256, 258, 259.

50 Uluslararası bir üne sahip maden sanat atölyelerinin bulunduğu İstanbul'un 1204 yılında Latinler tarafindan yağmalanması örnek verilebilir. Ayrıntılı bilgi için bkz. Belli ve Kayaoğlu, 1993a: 31, 46. banoğulları dönemine (1273-74 dolayı) kadar inmektedir. Ülkemizde Anadolu Selçuklu, Beylikler ve Erken Osmanlı dönemine ait olduğu kesin olarak bilinen madeni eserlerin sayısının azlığı dikkate alınırsa (Belli - Kayaoğlu 1993a: 46), 1273-1274 civarında inşa edilen bir hamamda bulunan ve ilk inşadan kaldığı yönünde fikir veren külhan kazanının günümüze ulaşması son derece önemlidir. İlki gibi üzerlerinde kitabe bulunmayan diğer iki örneğin, 1637 ve 1766-67 yıllarına ait Osmanlı eserleri olabileceğini düşünmekteyiz.

Çeşitli tarihi belgeler, Kastamonu'nun OsmanIı devrinde önemli bir kazancılık ve bakırcılık merkezi olduğuna işaret etmektedir. Kazanlarının, Anadolu'nun çeşitli vilayetlerine ve Anadolu dışına bakırdan mamül çeşitli kap-kacak ve alet-edevat ihraç eden Kastamonulu zanaatkârların elinden çıkmış olabileceğini düşünmekteyiz. Evliya Çelebinin "Zîrâ bu kazancılar cümle Kastamonuludur" ifadesi bu bakımdan önemlidir. Yakın zamanlara kadar şehirde bakırcılık ve kazancılık alanında canlı bir üretimin olduğu ve bilinmektedir.

Kazanların levha kalınlıkları, çapları ve birleştirme ayrıntılarına bakılınca külhan kazanları için geçerli olan geleneksel bakırcılık sınırları içerisinde oldukları görülmektedir (Tablo. 2-3).

Bir kap türü olarak kazanların kendi içerisinde sınıflandırılması bağlamında külhan kazanlarını müstakil bir grup olarak "külhan kazanları" başlığıyla veya işlevsel yakınlıkları sebebiyle gusülhane kazanlarıyla beraber "külhan ve gusülhane kazanları" başlığı altında sınıflandırmayı uygun görmekteyiz. Ancak işlev, biçim (tipoloji), boyut gibi farklı niteliklere göre farklı tasnifler de yapılabilir. 


\section{Tablolar}

Tablo 1: Kazanların Tarihçeleri, Imali ve Mülkiyeti Ile Ilgili Bazı Hususlar

\begin{tabular}{|c|c|c|c|c|c|c|}
\hline Kazan Adı & $\begin{array}{l}\text { Kazanın Ait } \\
\text { Olduğu Yapının } \\
\text { İnşa Tarihi / } \\
\text { Dönemi }\end{array}$ & $\begin{array}{l}\text { Yapının } \\
\text { bilinen } \\
\text { Onarımları }\end{array}$ & $\begin{array}{l}\text { Kazanın İmal Tarihi } \\
\text { Hakkında }\end{array}$ & $\begin{array}{l}\text { Kazanın } \\
\text { Sergilendiği } \\
\text { Yer }\end{array}$ & $\begin{array}{l}\text { İmal Edildiği } \\
\text { Maden / İmal } \\
\text { Tekniği }\end{array}$ & $\begin{array}{l}\text { Kazanların } \\
\text { Mülkiyeti }\end{array}$ \\
\hline $\begin{array}{l}\text { KASTAMONU } \\
\text { VAKIF HAMAMI } \\
\text { KAZANI }\end{array}$ & $\begin{array}{l}\text { 1273-74 dolayı } \\
\text { /Çobanoğulları }\end{array}$ & $1899-1900$ & $\begin{array}{l}\text { Muhtemelen ilk } \\
\text { inşadan kalma: } \\
\text { 1273-74 dolayı }\end{array}$ & $\begin{array}{l}\text { Kastamonu } \\
\text { İsmail Bey } \\
\text { (Kurşunlu) } \\
\text { Hanı }\end{array}$ & Bakır / Dövme & $\begin{array}{l}\text { Vakıflar } \\
\text { Genel } \\
\text { Müdürlüğü }\end{array}$ \\
\hline $\begin{array}{l}\text { KASTAMONU } \\
\text { DEDE SULTAN } \\
\text { HAMAMI } \\
\text { KAZANI }\end{array}$ & $\begin{array}{l}\text { 1514-15/ } \\
\text { Osmanlı }\end{array}$ & $\begin{array}{l}1766-67 \\
1948 \\
1985 \\
2006\end{array}$ & $\begin{array}{l}\text { Kazan 1766-67 } \\
\text { yllındaki tamirde } \\
\text { yenilenmiş }\end{array}$ & $\begin{array}{l}\text { Kastamonu } \\
\text { Pembe } \\
\text { (Balkapanı) } \\
\text { Han }\end{array}$ & Bakır / Dövme & $\begin{array}{l}\text { Vakıflar } \\
\text { Genel } \\
\text { Müdürlüğü }\end{array}$ \\
\hline $\begin{array}{l}\text { TOSYA TEKKE } \\
\text { HAMAMI } \\
\text { KAZANI }\end{array}$ & $\begin{array}{l}\text { Baninin ölüm } \\
\text { tarihi 1637'den } \\
\text { birkaç yıl önce? } \\
\text { / Osmanlı }\end{array}$ & --- & $\begin{array}{l}\text { Muhtemelen ilk } \\
\text { inşadan kalma: } \\
\text { 1637'den birkaç yıl } \\
\text { önce? }\end{array}$ & $\begin{array}{l}\text { Kastamonu } \\
\text { Münire } \\
\text { Medresesi } \\
\text { yakınında }\end{array}$ & Bakır / Dövme & $\begin{array}{l}\text { Vakıflar } \\
\text { Genel } \\
\text { Müdürlüğü }\end{array}$ \\
\hline
\end{tabular}

Tablo 2: Kazan Ölçüleri

\begin{tabular}{|c|c|c|c|c|c|c|}
\hline Kazan Adı & $\begin{array}{l}\text { Kazanın Çapı } \\
\text { (Ağız Kenarı } \\
\text { Dahil) }\end{array}$ & $\begin{array}{l}\text { Kazan } \\
\text { Derinliği }\end{array}$ & Orta Bombe Çapı & $\begin{array}{l}\text { Orta Bombe } \\
\text { Çevresi } \\
\text { Halka (Düz- } \\
\text { taban) Eni }\end{array}$ & $\begin{array}{l}\text { Orta Bombe } \\
\text { Yükseklik }\end{array}$ & $\begin{array}{l}\text { Ağız Kenar } \\
\text { Genişliği }\end{array}$ \\
\hline $\begin{array}{l}\text { KASTAMONU } \\
\text { VAKIF HAMAMI } \\
\text { KAZANI }\end{array}$ & $189.5-204.5 \mathrm{~cm}$ & $37 \mathrm{~cm}$ & $\begin{array}{l}114-129 \mathrm{~cm} . \\
\text { (Taban hizasında) }\end{array}$ & $20-25 \mathrm{~cm}$. & $15 \mathrm{~cm}$ & 6-7 cm. \\
\hline $\begin{array}{l}\text { KASTAMONU } \\
\text { DEDE SULTAN } \\
\text { HAMAMI } \\
\text { KAZANI }\end{array}$ & $165-166 \mathrm{~cm}$ & $32 \mathrm{~cm}$. & $\begin{array}{l}102 \text { - } 104 \text { cm. } \\
\text { (Taban hizasında) }\end{array}$ & $31-32.5 \mathrm{~cm}$ & $12 \mathrm{~cm}$ & $7-8 \mathrm{~cm}$ \\
\hline $\begin{array}{l}\text { TOSYA TEKKE } \\
\text { HAMAMI } \\
\text { KAZANI }\end{array}$ & $165-167 \mathrm{~cm}$ & $32 \mathrm{~cm}$. & $\begin{array}{l}58-58.5 \mathrm{~cm} . \text { (Tavan } \\
\text { hizasında) }\end{array}$ & Belirlenemiyor & $34 \mathrm{~cm}$. & Ağız Kenarı Yok \\
\hline
\end{tabular}

Tablo 3: Kazanlara Ait Bazı Teknik Ayrıntılar

\begin{tabular}{lllllll} 
Kazan Adı & $\begin{array}{c}\text { Levha } \\
\text { Sayısı }\end{array}$ & Levha Kalınlığı & $\begin{array}{l}\text { Levha } \\
\text { Birleştirme } \\
\text { Teknikleri }\end{array}$ & $\begin{array}{l}\text { Perçin Çivi Başı } \\
\text { Çapları }\end{array}$ & $\begin{array}{l}\text { Kaynak } \\
\text { Birleştirmede } \\
\text { Diş Derinliği }\end{array}$ & $\begin{array}{l}\text { Kaynak } \\
\text { Birleştirmede Diş } \\
\text { Genişliği }\end{array}$ \\
\hline $\begin{array}{l}\text { KASTAMONU } \\
\text { VAKIF HAMAMI } \\
\text { KAZANI }\end{array}$ & 4 & $0.4-0.5 \mathrm{~cm}$. & Perçin & $1.3-1.6 \mathrm{~cm}$. & $\begin{array}{l}\text { Kaynak } \\
\text { birleştirme yok }\end{array}$ & $\begin{array}{l}\text { Kaynak birleştirme } \\
\text { yok }\end{array}$ \\
\hline $\begin{array}{l}\text { KASTAMONU } \\
\text { DEDE SULTAN } \\
\text { HAMAMI } \\
\text { KAZANI }\end{array}$ & 8 & $0.3-0.4 \mathrm{~cm}$. & $\begin{array}{l}\text { Perçin ve } \\
\text { Bakır kaynağı } \\
\text { (Katı Lehim) }\end{array}$ & $1-1.4 \mathrm{~cm}$. & $\begin{array}{l}\text { Kaynak } \\
\text { birleştirme yok }\end{array}$ & $\begin{array}{l}\text { Kaynak birleştirme } \\
\text { yok }\end{array}$ \\
\hline $\begin{array}{l}\text { TOSYA TEKKE } \\
\text { HAMAMI } \\
\text { KAZANI }\end{array}$ & 12 & $0.3-0.7 \mathrm{~cm}$. & Perçin & $\begin{array}{l}1.5-1.9 \mathrm{~cm} . \\
\text { (küçüklerde) } \\
4.5-5.2 \mathrm{~cm} . \\
\text { (büyüklerde) }\end{array}$ & $\begin{array}{l}\text { Ortalama 1.5 } \\
\mathrm{cm} .\end{array}$ & $2.5-5 . \mathrm{cm}$. \\
\hline
\end{tabular}




\section{Kaynaklar}

\section{Basılı Kaynaklar ve Tezler}

Anonim (1997a). "Bakır". Eczacıbaşı Sanat Ansiklopedisi, C. 1. İstanbul : Yapı Endüstri Merkezi Yayınları. s. 182.

Anonim (1997b). "Külhan". Eczacıbaşı Sanat Ansiklopedisi, C. 2. İstanbul : Yapı Endüstri Merkezi Yayınları. s. 1075.

Arseven, Celâl Esad (1965). Sanat Ansiklopedisi. Ankara : Milli Eğitim Basımevi. C. 2.

Arslan, Erdal (2012). "Kastamonu'da Beylikler Döneminden Günümüze Ulaşan Vakıf Eserleri". Kuzey Anadolu Beylikler Dönemi Sempozyumu Bildiriler (Editör: Halil Çetin). Çankırı : Çankırı Karatekin Üniversitesi Yayınları. s. 244-275.

Aru, Kemal Ahmet (1949). Türk Hamamları Etüdü. İstanbul: İstanbul Teknik Üniversitesi, Mimarlık Fakültesi Yayını.

Aslanapa, Oktay (2011). Türk Sanat. İstanbul: Remzi Kitabevi.

Avcı, Cemal (2012). “19. Yüzyıl Sonlarında Kastamonu Vilayeti". Abant İzet Baysal Üniversitesi Sosyal Bilimler Enstitüsü Dergisi, 24: s. 1734.

Barışta, Hatice Örcün (2015). Türk El Sanatları. Ankara : Atatürk Kültür Merkezi Yayınları. C. 2. Başak, Oktay (2010). "Taş Çağı'ndan Tunç Çağı'na Anadolu'da Maden Sanatın Gelişimi ve Kullanımı", Atatürk Üniversitesi, Güzel Sanatlar Enstitüsü Dergisi, 2: s. 15-33.

Belli, Oktay - ve İzzet Günday Kayaoğlu (1993a). Anadolu'da Türk Bakırcılık Sanatının Gelişimi. İstanbul: Sandoz Kültür Yayınları.

Belli, Oktay ve İzzet Günday Kayaoğlu (1993b). "Bakırcılar". Dünden Bugüne İstanbul Ansiklopedisi, 1, İstanbul. s. 552-554.

Belli, Oktay ve İzzet Günday Kayaoğlu (1995). "Kastamonu Bakırcılığı". Kültür ve Sanat 27
(Kastamonu Özel Sayısı). Ankara: İş Bankası Yayını. s. 44-46.

Bilici, Zeki Kenan (1995). "Kastamonu Balkapanı Hanı Tarihlendirilmesi ve Restorasyonu Problemi". 9. Milletlerarası Türk Sanatları Kongresi, (23-27 Eylül 1991 Atatürk Kültür Merkezi Istanbul). C. 1. Ankara. s. 379-383.

Bilici, Zeki Kenan (1991). Kastamonu'da Türk Devri Mimarisi ve Şehir Dokusunun Gelişimi (18. Yüzyıl Sonuna Kadar). Ankara Üniversitesi, Sosyal Bilimler Enstitüsü, Arkeoloji ve Sanat Tarihi (Sanat Tarihi) Ana Bilim Dalı, Yayınlanmamış Doktora Tezi. Ankara.

Birkan, Seçil (2005). İslamiyet Öncesi Orta Asya Türk Maden Sanatının Gelişimi (M. Ö. IV-M. S. $X$. Yüzyıllar). Ankara Üniversitesi Sosyal Bilimler Enstitüsü, Tarih Anabilim Dalı, Yayınlanmamış Yüksek Lisans Tezi. Ankara.

Bodur, Fulya (1987). Türk Maden Sanat. İstanbul: Türk Kültürüne Hizmet Vakfi Yayınları.

Cunbur, Müjgan (1988). "Kastamonu Tarihinde Ahiler ve Esnaf Kuruluşları". Türk Tarihinde ve Kültüründe Kastamonu Tebliğler (19-21 Ekim 1988). Kastamonu. s. 7-15.

Çakmak, Canan (2002). Tire Hamamları. Ankara: Kültür Bakanlığı Yayını.

Çifci, Fazıl (1995). Kastamonu Camileri-Türbeleri ve Diğer Tarihi Eserler. Ankara: Türkiye Diyanet Vakfi Yayını.

Çoruhlu, Yaşar (2007). Erken Devir Türk Sanat. İstanbul: Kabalcı Yayınevi.

Çoruhlu, Yaşar (2009). “iç̧ Asya Türk Topluluklarına Ait Tunç Tören Kazanları ve Çin Sanatındaki Örneklerine Mukayeseli Bakış". 6. Uluslararası Türk Kültürü Kongresi Bildirileri, 3. Ankara: Atatürk Kültür Merkezi Başkanlığı Yayınları. s. 1173-1193.

Dağlı, Yücel (2005). "Evliya Çelebi Seyahatnâmesi'nde Kastamonu". Ikinci Kastamonu Kültür 
Sempozyumu Bildirileri (18-20 Eylül 2003). Ankara: Gazi Üniversitesi Illetişim Fakültesi Basımevi. s. 195-205.

Darkot, Besim (1977). "Kastamonu”. İslam Ansiklopedisi, C. 6. Milli Eğitim Bakanlığı Yayını. s. 399403.

Dursun, Necla (2014). "Çorum'da Bakırcılık". Turkish Studies - International Periodical For The Languages, Literature and History of Turkish or Turkic, 9/5: 799-824.

Eraslan, Aylin (2009). "Antakya ve Çevresinde El Zanaatları". Mustafa Kemal Üniversitesi Sosyal Bilimler Enstitüsü Dergisi, 6 /12: 373-402.

Erginsoy, Ülker (1997). “Maden”. Eczacıbaşı Sanat Ansiklopedisi, 2. İstanbul: Yapı Endüstri Merkezi Yayınları. s. 1138-1147.

Erginsoy, Ülker (1978). İslam Maden Sanatının Gelişmesi. İstanbul: Kültür Bakanlığı Yayınları.

Eyüpgiller, Kemal Kutgün (1999). Bir Kent Tarihi Kastamonu. İstanbul: Eren Yayıncılık.

Faroqhi, Suraiya. (1994). Osmanlıda Kentler ve Kentliler (Türkçesi: Neyyir Kalaycıoğlu). İstanbul: Tarih Vakfi Yurt Yayınları.

Gökoğlu, Ahmet (1952). Paphlagonia Paflagonya Gayri Menkul Eserler ve Arkeolojisi. Kastamonu: Doğrusöz Matbaası.

Gülensoy, Tuncer (1994). “Anadolu'da Türk Bakırcılık Sanatının Gelişimi". Milli Folklor, 3/23. Ankara. s. 6-7.

Güzey, Ahmet Rıfat (2001). “XVII. Yüzyıl Sonu XVIII. Yüzyıl Başlarında Kastamonu". Birinci Kastamonu Kültür Sempozyumu Bildirileri. Kastamonu: Kastamonu Valiliği Yayını. s. 121-136 Hasol, Doğan (1998). Ansiklopedik Mimarlık Sözlüğü. İstanbul: Yapı-Endüstri Merkezi Yayınları.

İbret, B. Ünal (2001). “Küre'de Bakır Cevheri Üretimi ve Bakır Madenciliğinin Küre Ekonomisindeki Yeri". Birinci Kastamonu Kültür Sempoz- yumu Bildirileri. Kastamonu: Kastamonu Valiliği Yayını. s. 433-450.

İbret, B. Ünal (2003). "Tarihi İpek Yolu Üzerindeki Bir Anadolu Şehri Tosya (Kuruluşu ve Gelişmesi)". Marmara Coğrafya Dergisi, 8: s. 53-82.

Karakaya, Enis (2006). “Nasrullah Camii ve Külliyesi". Türkiye Diyanet Vakfi İlam Ansiklopedisi, 32: s. 424-425.

Karpuz, Emine (2002). “Anadolu Mutfaklarında Kullanılan Bakır Kaplar ve Osmanlı Dönemi Örnekleri". Türkler, 12. Ankara: Yeni Türkiye Yayınları. s. 425-432.

Kayabaşı, Nuran (1997). “Çorum'da Dövme Bakırcılık". V. Milletlerarası Türk Halk Kültürü Kongresi, Maddi Kültür Seksiyon Bildirileri. Ankara: Kültür Bakanlığı Yayını. s. 225-238.

Kayaoğlu, İzzet Günday (1985). "Maden İsçiliginin Dünü, Bugünü ve Yarını”. Türkiye'de Sanatın Bugünü ve Yarını (Tebliğler), Hacettepe Üniversitesi, Güzel Sanatlar Fakültesi, I. Ulusal Sanat Sempozyumu, 17-18 Nisan 1985. s. 439444.

Kayaoğlu, İzzet Günday (1991). "Kahraman Maraş'ta Bakırcılık". Kültür ve Sanat, 10 (Kahraman Maraş Özel Sayısı). Ankara: İş Bankası Yayını. s. 30-35.

Kazmaz, Süleyman (1997). Kastamonu Geçmiş Günler ve Küçük Sanat Hayat. Ankara: Türk Halk Kültürünü Araştirma ve Tanıtma Vakfi Yayını.

Kerametli, Can (1974). "Türk ve İslâm Eserleri Müzesinde Erken İslâm Devri Maden İşçiliği". Türk Etnografya Dergisi, 14. Ankara. s. 115125.

Koneska, Elizabeta (1992). "Makedonya'da Kazancılığın Gelişimi Üstüne”. IV. Milletlerarası Türk Halk Kültürü Kongresi Bildirileri, 5. Cilt (Maddi Kültür). Ankara: Kültür Bakanlığı Halk Kültürlerini Araştrrma ve Geliştirme Genel Müdürlüğü Yayını. s. 141-147. 
Kuban, Doğan (2007). Osmanlı Mimarisi. İstanbul: Yapı Endüstri Merkezi Yayınları.

Kuşoğlu, Mehmet Zeki (2002). "Osmanlı Maden Sanat". Türk Dünyası Kültür Atlası - Osmanlı Dönemi, 5. İstanbul: Türk Kültürüne Hizmet Vakfi Yayınları. s. 194-205.

Kuşoğlu, Mehmet Zeki (2006). Resimli Ansiklopedik Kuyumculuk ve Maden Terimleri Sözlüğü. İstanbul: Ötüken Yayınları.

Leventoğlu, Sibel Ağce (2006). Gaziantep Hasan Süzer Etnografya Müzesi'nde Bulunan Ortaçağ ve Sonrası Döneme Ait Madeni Mutfak Kapları. Yüzüncü Yıl Üniversitesi, Sosyal Bilimler Enstitüsü, Sanat Tarihi Anabilim Dalı, Yayınlanmamış Yüksek Lisans Tezi. Van.

Maden, Fahri (2004). 18. Yüzyılın Sonlarında Kastamonu (Şeriye Sicillerine Göre). Ondokuz Mayıs Üniversitesi, Sosyal Bilimler Enstitüsü, Yayınlanmamış Yüksek Lisans Tezi. Samsun.

Maden, Fahri (2007). "XVIII. Yüzyıl Sonu XIX. Yüzyıl Başlarında Kastamonu'da Esnaf Grupları Zanaatkârlar ve Ticari Faaliyetler". Karadeniz Araştırmaları, 15: s. 149-167.

Maden, Fahri (2004). Seyyahların Gözüyle Kastamonu. İstanbul: Roza Yayınevi.

Memişoğlu, Ferhan (1973). "Harput Bakırcılığı". Türk Etnografya Dergisi, 13. Ankara. s. 33-54.

Naldan Funda (2014). "Erzincan Bakırcılığı". Turkish Studies - International Periodical For The Languages, Literature and History of Turkish or Turkic, 9/10: s. 775-796.

Önge, Yılmaz (1995). Anadolu'da XII-XIII. Yüzyıl Türk Hamamları. Ankara: Vakıflar Genel Müdürlüğü Yayınları.

Önge, Yılmaz (1988). “Anadolu Türk Hamamları Hakkında Genel Bilgiler ve Mimar Koca Sinan'ın İnşa Ettiği Hamamlar". Mimarbaşı Koca Sinan Yaşadığı Çağ ve Eserleri (Editör: S. Bayram), 1, İstanbul: Vakıflar Genel Müdürlüğü Yayınları. s. 403-428.
Pakalın, Mehmet Zeki (1983). Osmanlı Tarih Deyimleri ve Terimleri Sözlüğü, 2. İstanbul: Milli Eğitim Bakanlığı Yayını.

Şakar, Muzaffer Fehmi (2008). "Kastamonu Vakıfları (1486-1865)". Üsküdar'a Kadar Kastamonu (Hazırlayan: L. Seymen), İstanbul: Yapı Kredi Yayınları. s. 243-257.

Şahin, İlhan (2001). "Kastamonu". Türkiye Diyanet Vakfi Islam Ansiklopedisi, 24: s. 584-588.

Şehitoğlu, Elif (2008). Bursa Hamamları, İstanbul: Tarih Vakfi Yurt Yayınları.

Tan, Nail, (1989). "Kastamonu'da Yaşayan Halk Sanat ve Zanaatları”. Kültür ve Sanat, 3. Ankara: İş Bankası Yayını. s. 36-40.

Tayla, Hüsrev (2007). Geleneksel Türk Mimarisinde Yapı Sistem ve Elemanları, I. İstanbul: Türkiye Anıt Çevre Turizm Değerlerini Koruma Vakf.

Tızlak, Fahrettin (1999a). “Osmanlılardan Önce Türklerde Madencilik". Türkler, 7. Yeni Türkiye Yayınları. s. 407-414.

Tızlak, Fahrettin (1999b). "Osmanlı Devletinde Madencilik". Osmanlı, 3. Yeni Türkiye Yayınları. s. $312-321$.

Tuluk, Hasan ve Ömer İskender Tuluk (2016). "Geleneksel Çorum Evlerinde Metal Aksesuarlar". Uluslararası Bütün Yönleriyle Çorum Sempozyumu (28 - 30 Nisan 2016) Bildiriler Kitabı, 2. Editör. Z. Işık. Çorum: Hitit Üniversitesi Yayını. Ülgen, Ali Saim (1989). Mimar Sinan Yapıları-Katalog (Yayına Hazırlayanlar, F. Yenişehirlioğlu, E. Madran) Ankara: Türk Tarih Kurumu Yayını.

Ürer, Harun (2002). İzmir Hamamları. Ankara: Kültür Bakanlığı Yayını.

Yakupoğlu, Cevdet (2001). “Candaroğulları Döneminde Kastamonu'da İçtimaî ve İktisadî Hayat". Birinci Kastamonu Kültür Sempozyumu Bildirileri. Kastamonu: Kastamonu Valiliği Yayını. s. 55-80. 
Yakupoğlu, Cevdet (2009). "Selçuklular, Beylikler ve Osmanlılar Döneminde Kastamonu Çevresinde Ahiler". Erdem, 10/55: s. 157-174.

Yücel, Yaşar (1993a). "Çobanoğulları”. Türkiye Diyanet Vakfi Islam Ansiklopedisi, 8: s. 354-355. Yücel, Yaşar (1993b). "Candaroğulları". Türkiye Diyanet Vakfi Islam Ansiklopedisi, 7: s. 146-149.

\section{Elektronik kaynaklar}

Google Earth (01.09.2016)

http://www.tosyahaberleri.com/asayis/tarihi-tekke-hamaminda-yangin-h4726.html (10.09.2016) http://yumurtaliekmek.com/bakircilik-nedir-bakir-urunler-nelerdir/ (12.09.2016) http://w3.balikesir.edu.tr/ ay/lectures/mmg/ lecture5.pdf (17.09.2016)

http://tosyatekkehamam.tr.gg/ (12.09.2016) http://w3.balikesir.edu.tr/ ay/lectures/mmg/ lecture5.pdf - (17.09.2016)

http://www.gto.org.tr/Bakircilar-Carsisi-fotogaleri-3.html (17.09.2016) 